\title{
FLUÊNCIA DE GEOTÊXTEIS
}

\author{
Carina Maia Lins Costa
}

Dissertação apresentada à Escola de Engenharia de São Carlos da Universidade de São Paulo, como parte dos requisitos para a obtenção do título de Mestre em Geotecnia

ORIENTADOR: Prof. Dr. Benedito de Souza Bueno

São Carlos

1999 
Ficha catalográfica preparada pela Seção de Tratamento da Informação do Serviço de Biblioteca - EESC - USP

\begin{tabular}{|c|c|}
\hline C837f & $\begin{array}{l}\text { Costa, Carina Maia Lins } \\
\text { Fluência de Geotêxteis / Carina Maia Lins } \\
\text { Costa. São Carlos, } 1999 .\end{array}$ \\
\hline & $\begin{array}{l}\text { Dissertação (Mestrado) - Escola de } \\
\text { Engenharia de São Carlos - Universidade de São } \\
\text { Paulo, 1999. } \\
\text { Orientador: Prof. Dr. Benedito de Souza } \\
\text { Bueno }\end{array}$ \\
\hline & 1. Geotêxtil. I. Título \\
\hline
\end{tabular}




\section{FOLHA DE APROVAC̄̃O}

Candidata: Engenheira CARINA MAIA LINS COSTA

Dissertação defendida e aprovada em 08-07-1999 pela Comissão Julgadora:

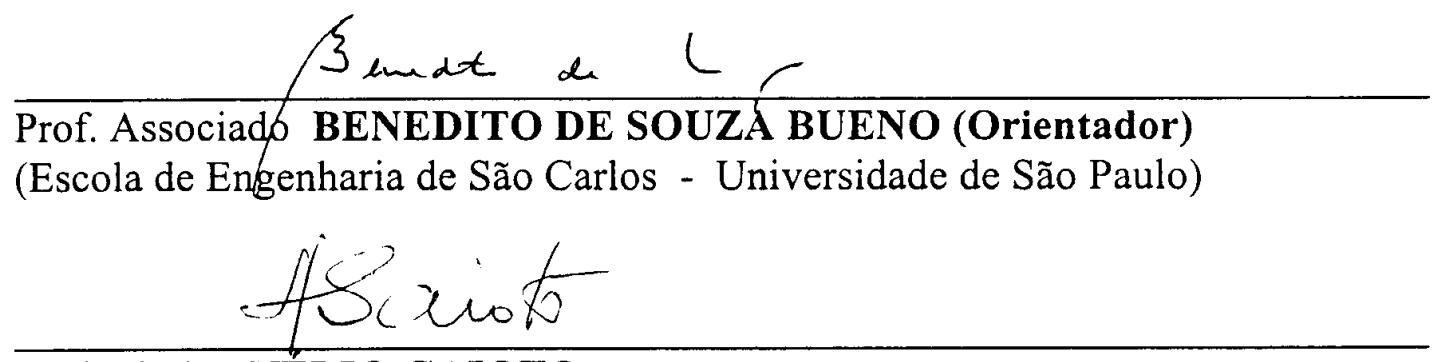

Prof. Titular NELIO GAIOTO

(Escola de Engenharia de São Carlos - Universidade de São Paulo)
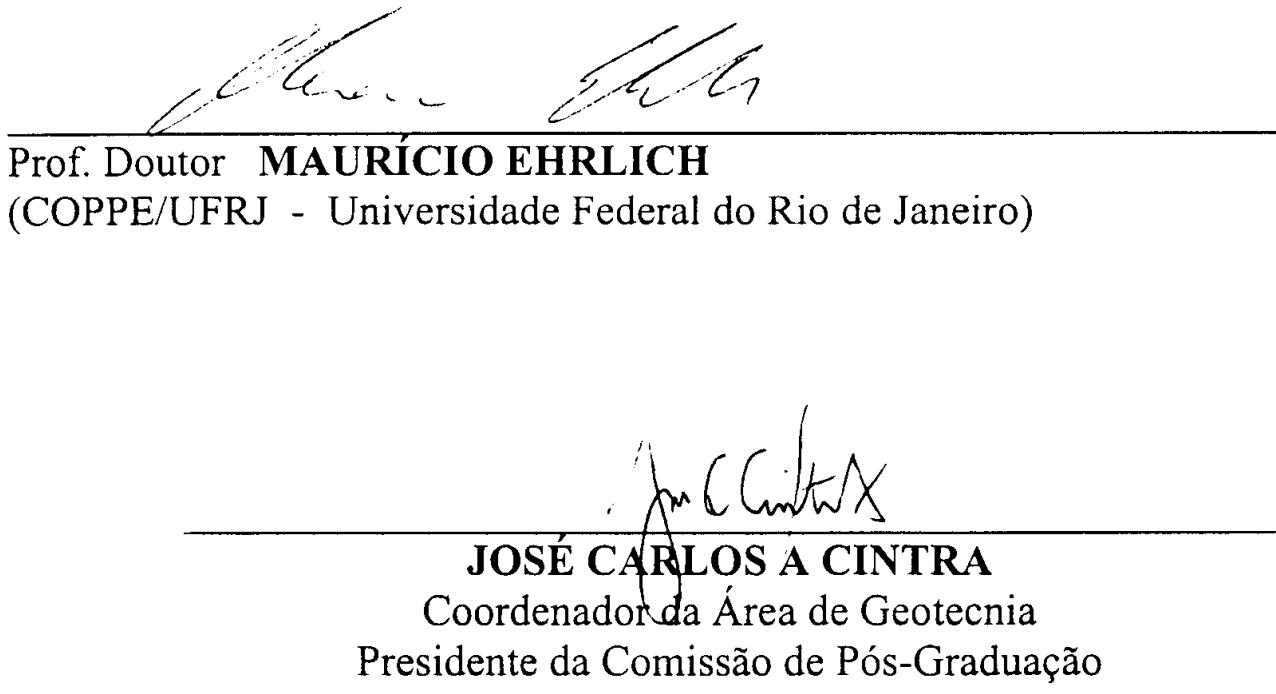
Ao meu esposo, Yuri; aos meus pais, Carlos e Heliana; aos meus avós, José Geraldo, Elvia e Maria; à minha irmã, Cristina;

dedico esta dissertação. 


\section{AGRADECIMENTOS}

Ao Prof. Dr. Benedito de Souza Bueno, pela paciência, amizade e excelente orientação durante a elaboração deste trabalho.

À Ober e à Amoco do Brasil, pelo auxílio financeiro e pela doação de geotêxteis.

À OPP Petroquímica, pelo auxílio financeiro.

À Bidim Indústria e Comércio, pelo acesso à biblioteca da empresa e pela doação de geotêxteis.

À Sansuy, pela confecção da bolsa inflável.

Ao Prof. Dr. Orêncio Monje Vilar, pela colaboração e sugestões apresentadas no decorrer do trabalho.

Ao engenheiro Dr. Maurício Abramento, pelas sugestões apresentadas no exame de Qualificação.

Ao engenheiro Roberto T. Aramaki, pela ajuda na coleta de material bibliográfico e pelo incentivo durante o desenvolvimento deste trabalho.

Aos funcionário do Departamento de Geotecnia da EESC, especialmente às secretárias Regina Dibo e Maristela Batissaco e aos técnicos José Luís Guerra, Oscar dos Santos Neto, Antônio Garcia e Benedito Souza, pela inestimável ajuda durante o desenvolvimento dos equipamentos e a realização dos ensaios.

Aos amigos Marcelo Ferreira e Sidnei Teixeira, pela ajuda na confecção dos equipamentos e na realização dos ensaios.

À Coordenadoria de Aperfeiçoamento de Pessoal de nível superior - CAPES, pela concessão da bolsa de estudo.

À minha família, pelo apoio e incentivo nos momentos difíceis. 


\section{SUMÁRIO}

LISTA DE FIGURAS

LISTA DE TABELAS $\quad \mathrm{V}$

LISTA DE ABREVIATURAS, SIGLAS E SÍMBOLOS vi

RESUMO viii

ABSTRACT ix

1 INTRODUÇÃO

1.1 Objetivos do trabalho 2

1.2 Organização do texto 3

2 REVISÃO BIBLIOGRÁFICA 4

2.1 Geotêxteis: Princípios gerais e aspectos relacionados à fluência 4

2.1.1 Polímeros 6

2.1.1.1 Generalidades 6

2.1.1.2 Classificação dos polímeros $\quad 6$

2.1.1.3 Estrutura macromolecular dos polímeros 9

2.1.1.4 Polímeros utilizados na fabricação dos geotêxteis 11

2.1.2 Tipos de geotêxteis 14

2.1.2.1 Geotêxteis tecidos 14

2.1.2.2 Geotêxteis não-tecidos $\quad 15$

2.2 Fluência de geotêxteis 17

2.2.1 Conceitos básicos 17

2.2.2 Ensaios de fluência 19

$\begin{array}{ll}\text { 2.2.2.1 Metodologia de ensaio } & 19\end{array}$ 
2.2.2.2 Equipamentos utilizados 25

2.2.3 Fatores que afetam a fluência 35

2.2.3.1 Tipo de polímero e tipo de geotêxtil 35

$\begin{array}{ll}\text { 2.2.3.2 Temperatura } & 37\end{array}$

2.2.3.3 Presença de confinamento 38

2.2.4 O papel da fluência no dimensionamento de muros e taludes de solos $\quad 40$ reforçados

3 MATERIAIS E MÉTODOS 46

3.1 Fluência não-confinada 46

3.1.1 Equipamento desenvolvido 46

3.1.2 Geotêxteis utilizados 49

3.1.3 Ensaios realizados $\quad 50$

3.1.3.1 Preparação dos corpos de prova 51

3.1.3.2 Montagem e execução dos ensaios $\quad 51$

3.2 Fluência confinada

3.2.1 Equipamento desenvolvido

3.2.1.1 Descrição geral 53

3.2.1.2 A bolsa inflável 56

3.2.1.3 Sistemas para obtenção das deformações do corpo de prova 56

3.2.1.4 Células de carga $\quad 59$

3.2.1.5 Verificação da carga atuante no corpo de prova 62

3.2.2 Geotêxtil utilizado $\quad 66$

3.2.3 Ensaios realizados $\quad 66$

3.2.3.1 Preparação dos corpos de prova $\quad 67$

$\begin{array}{ll}\text { 3.2.3.2 Montagem e execução dos ensaios } & 70\end{array}$

4 APRESENTAÇÃO E ANÁLISE DOS RESULTADOS 71

$\begin{array}{ll}\text { 4.1 Apresentação dos resultados } & 71\end{array}$ 
4.1.1 Fluência não-confinada

4.1.2 Fluência confinada $\quad 73$

4.2 Análise dos resultados $\quad 76$

4.2.1 Fluência não-confinada 76

4.2.2 Fluência confinada $\quad 80$

5 CONCLUSÕES E SUGESTÕES PARA PESQUISAS FUTURAS 89

5.1 Conclusões $\quad 89$

$\begin{array}{ll}5.2 \text { Sugestões para pesquisas futuras } & 90\end{array}$

REFERÊNCIAS BIBLIOGRÁFICAS 92 


\section{LISTA DE FIGURAS}

FIGURA 2.1 - Exemplos de aplicação de geotêxteis (a) separação de materiais distintos (b)envolvendo conduto utilizado para drenagem (c) estrutura de contenção $(\mathrm{d})$ aterro reforçado

FIGURA 2.2 - Formação do polipropileno por adição 7

FIGURA 2.3 - Formação do poliéster por condensação 7

FIGURA 2.4 - Representação esquemática de termoplásticos e termorrígidos 8

FIGURA 2.5 - Processo de fabricação de fibras 9

FIGURA 2.6 - Regiões amorfas e cristalinas 10

FIGURA 2.7 - Estrutura química de alguns monômeros 11

FIGURA 2.8 - Curva carga x deformação para cinco fibras a $20^{\circ} \mathrm{C} \quad 12$

FIGURA 2.9 - Estrutura de um geotêxtil tricotado 14

FIGURA 2.10 - Tipos de fibras $\quad 15$

FIGURA 2.11 - Geotêxteis tecidos (ampliação de 8x) (a) multifilamentos (b) laminetes 15

FIGURA 2.12 - Processo de fabricação "Spunbonding” 16

FIGURA 2.13 - Estruturas não tecidas (a) agulhada (b) termoligada 17

FIGURA 2.14 - Possíveis fases de fluência apresentadas por geotêxteis (a) deformação x tempo (b) taxa de deformação x tempo 18

FIGURA 2.15 - Predominância de algum estágio de fluência 19

FIGURA 2.16 - Curvas deformação x tempo em ensaios de fluência 20

FIGURA 2.17 - Curvas isócronas carga-deformação 21

FIGURA 2.18 - Curvas Sherby-Dorn 21

FIGURA 2.19 - (a) Modelo de Boltzmann (b) modelo de Burger 22

FIGURA 2.20 - Modelo reológico de Boltzmann a "n” elementos 23

FIGURA 2.21 - (a) Modelo com quatro elementos (b) modelo com cinco elementos 24

FIGURA 2.22 - Equipamento usado em ensaio de fluência não confinada 26

FIGURA 2.23 - Efeito de tensões cisalhantes em ensaios confinados 27

FIGURA 2.24 - Sistema de confinamento 28

FIGURA 2.25 - Equipamento de tração 29 
FIGURA 2.26 - Equipamento de tração confinada 30

FIGURA 2.27 - Equipamento de tração confinada 31

FIGURA 2.28 - Distribuição das tensões de cisalhamento no equipamento proposto por MAcGOWN et al. (1982) 32

FIGURA 2.29 - Sistema utilizado para obter as deformações do geotêxtil 33

FIGURA 2.30 - Vista geral do equipamento para ensaio de fluência confinada 34

FIGURA 2.31 - Equipamento para ensaio de fluência confinada 35

FIGURA 2.32 - Curvas de fluência para fibras de diferentes polímeros (a) 20\% da resistência à tração (b) $60 \%$ da resistência à tração 36

FIGURA 2.33 - Fluência de um geotêxtil de PP a diferentes temperaturas e níveis de $\begin{array}{ll}\text { carregamento } & 38\end{array}$

FIGURA 2.34 - Resultados de ensaios de fluência de geotêxteis 39

FIGURA 2.35 - Mecanismos envolvidos na estabilidade externa (a) tombamento (b) deslizamento (c) capacidade de carga da fundação $\quad 40$

FIGURA 2.36 - Mecanismo de ruptura geral 41

FIGURA 2.37 - Zona ativa e resistente de um maciço reforçado 41

FIGURA 2.38 - Determinação da carga de ruptura por fluência 44

FIGURA 3.1 - Equipamento de fluência não-confinada 46

FIGURA 3.2 - Esquema das garras $\quad 47$

FIGURA 3.3 - Detalhe da fixação da garra no suporte 47

FIGURA 3.4 - Prato e haste utilizados para a aplicação da carga 48

FIGURA 3.5 - Pontos utilizados para acompanhar o deslocamento entre garras 49

FIGURA 3.6 - Equipamento usado para erguer os pesos 52

FIGURA 3.7 - Esquema de um geotêxtil reforçado 53

FIGURA 3.8 - Equipamento de fluência confinada 54

FIGURA 3.9 - Caixa de ensaios 54

FIGURA 3.10 - Detalhe da fixação da caixa 55

FIGURA 3.11 - Corte esquemático do equipamento de fluência confinada 56

FIGURA 3.12 - Bolsa inflável 56

FIGURA 3.13 - Esquema dos pontos de fixação das hastes 57

FIGURA 3.14 - Hastes para medidas internas de deslocamento 57 
FIGURA 3.15 - Peça de conexão presa ao relógio 58

FIGURA 3.16 - Relógios acoplados às hastes 58

FIGURA 3.17 - Sistema para medidas externas de deslocamento 59

FIGURA 3.18 - Célula de carga $\quad 59$

FIGURA 3.19 - Esquema de uma célula de carga 60

FIGURA 3.20 - Células de carga fixadas no geotêxtil 61

FIGURA 3.21 - Calibração de uma célula de carga 62

FIGURA 3.22 - Configurações de alguns testes realizados 63

FIGURA 3.23 - Esquema de ensaios de fluência confinada com membranas $\quad 65$

FIGURA 3.24 - Colocação da membrana $\quad 67$

$\begin{array}{ll}\text { FIGURA } 3.25 \text { - Membrana já fixada } & 68\end{array}$

FIGURA 3.26 - Curva granulométrica do solo argiloso $\quad 68$

FIGURA 4.1 - Deformação total x tempo (ensaio NC1) 71

FIGURA 4.2 - Deformação total x tempo (ensaios NC2, NC4 e NC5) 72

FIGURA 4.3 - Deformação total x tempo (ensaios NC6, NC8 e NC9) 72

FIGURA 4.4 - Deformação total x tempo (ensaio NC3) 73

FIGURA 4.5 - Deformação total x tempo (ensaio NC7) 73

FIGURA 4.6 - Deformação total x tempo (ensaio C1) 74

FIGURA 4.7 - Deformação total x tempo (ensaio C2) 74

FIGURA 4.8 - Deformação total x tempo (ensaio C3) 75

FIGURA 4.9 - Deformação total x tempo (ensaio C4) 75

FIGURA 4.10 - Ajustes realizados para o geotêxtil B 77

FIGURA 4.11 - Ajustes realizados para o geotêxtil C 77

FIGURA 4.12 - Deformação total x tempo para geotêxteis de PET e PP com 60\% de suas resistências à tração (ensaios NC1 e NC5) 79

FIGURA 4.13 - Comparação entre geotêxteis de polipropileno (ensaios NC3 e NC7) 80

FIGURA 4.14 - Comparação entre ensaios não confinados e confinados, $40 \%$ da resistência à tração (ensaios NC3 e C1) 81

FIGURA 4.15 - Taxa de deformação x tempo - 40\% da resistência à tração (ensaios $\mathrm{NC} 3$ e C1) $\quad 82$

FIGURA 4.16 - Ensaios C1 e C2 (40\% da resistência à tração) 84 
FIGURA 4.17 - Resultados de ensaios confinados - 40\% da resistência à tração e 50 $\mathrm{kPa}$ (ensaios C1, C3 e C4)

FIGURA 4.18 - Estrutura do geotêxtil B (ampliação de 50x)

FIGURA 4.19 - Geotêxtil B preparado pelo processo 1 após ensaio (ampliação de $50 \mathrm{x})$

FIGURA 4.20 - Geotêxtil B preparado pelo processo 2 após ensaio - região aparentemente mais impregnada (ampliação de 50x)

FIGURA 4.21 - Geotêxtil B preparado pelo processo 2 após ensaio - região aparentemente menos impregnada (ampliação de 50x) 


\section{LISTA DE TABELAS}

TABELA 2.1 - Propriedades básicas de alguns polímeros 11

TABELA 2.2 - Coeficientes de segurança para fluência 44

TABELA 2.3 - Coeficientes de segurança parciais 45

TABELA 3.1 - Propriedades dos geotêxteis utilizados 49

TABELA 3.2 - Resultados dos ensaios de tração de faixa larga 50

TABELA 3.3 - Ensaios de fluência não-confinada 50

TABELA 3.4 - Resultados obtidos para os ensaios apresentados na Figura 3.22 64

TABELA 3.5 - Ensaios confinados 66

TABELA 3.6 - Caracterização do solo argiloso 69

TABELA 3.7 - Ensaios confinados com modificações na preparação do corpo de prova 70

TABELA 4.1 - Acréscimo da deformação entre 1 min e 7500 horas 76

TABELA 4.2 - Valores obtidos nos ajustes dos ensaios de longa duração para geotêxteis B e C 78

$\begin{array}{lll}\text { TABELA } & 4.3 \quad \text { Valores obtidos nos ajustes dos ensaios NC3 e NC7 } & 80\end{array}$

TABELA 4.4 - Constantes obtidas nos ajustes dos ensaios NC3 e C1 82 


\title{
LISTA DE ABREVIATURAS, SIGLAS E SÍMBOLOS
}

\author{
ABNT - Associação Brasileira de Normas Técnicas \\ ASTM - American Society for Testing and Materials \\ HDPE - Polietileno de alta densidade \\ LDPE - Polietileno de baixa densidade \\ NBR - Norma Brasileira Registrada \\ PA - Poliamida \\ PE - Polietileno \\ PET - Poliéster \\ PP - Polipropileno \\ PVC Policloreto de vinila \\ b - Constante obtida em ajuste logarítmico \\ $\mathrm{CS}_{\mathrm{DB}}$ - Coeficiente de segurança para degradação biológica \\ $\mathrm{CS}_{\mathrm{DI}}$ - Coeficiente de segurança para danos de instalação \\ $\mathrm{CS}_{\mathrm{DQ}}$ - Coeficiente de segurança para degradação química \\ $\mathrm{CS}_{\mathrm{FL}}$ - Coeficiente de segurança para fluência \\ c - Constante obtida em ajuste logarítmico \\ D - Diâmetro (mm) \\ d - Constante obtida em ajuste logarítmico \\ E - Módulo de elasticidade \\ e - Constante obtida em ajuste logarítmico \\ e $e_{\text {máx }} \quad$ Índice de vazios máximo \\ $\mathrm{e}_{\min } \quad$ - Índice de vazios mínimo \\ IP - Índice de plasticidade (\%) \\ LL - Limite de liquidez (\%) \\ LP - Limite de plasticidade (\%) \\ P - Força aplicada \\ P' Carga atuante
}




$$
\begin{array}{ll}
\mathrm{R}^{2} & - \text { Coeficiente de determinação } \\
\mathrm{T}_{\mathrm{adm}} & - \text { Resistência admissível à tração } \\
\mathrm{T}_{\mathrm{g}} & - \text { Temperatura de transição vítrea }\left({ }^{0} \mathrm{C}\right) \\
\mathrm{T}_{\mathrm{m}} & - \text { Temperatura de fusão cristalina }\left({ }^{0} \mathrm{C}\right) \\
\mathrm{T}_{\mathrm{ult}} & - \text { Resistência última à tração } \\
\mathrm{t} & - \text { Tempo (horas }) \\
\mathrm{W}_{\mathrm{ot}} & - \text { Umidade ótima }(\%) \\
\varepsilon & - \text { Deformação total (\%) } \\
\varepsilon_{0} & - \text { Deformação imediata } \\
\varepsilon_{\mathrm{I}} & - \text { Deformação primária } \\
\varepsilon_{\mathrm{II}} & - \text { Deformação secundária } \\
\varepsilon_{\mathrm{III}} & - \text { Deformação terciária } \\
\varepsilon^{\mathrm{pl}} & - \text { Deformação plástica } \\
\gamma_{\mathrm{dmáx}} & - \text { Peso específico seco máximo }\left(\mathrm{kN} / \mathrm{m}^{3}\right) \\
\gamma_{\mathrm{s}} & - \text { Peso específico dos sólidos }\left(\mathrm{kN} / \mathrm{m}^{3}\right) \\
\eta & - \text { Viscosidade } \\
\sigma & - \text { Tensão } \\
\tau & - \text { Tensão de cisalhamento } \\
&
\end{array}
$$




\section{RESUMO}

COSTA, C. M. L. (1999). Fluência de geotêxteis. São Carlos, 1999. 97p. Dissertação (Mestrado) - Escola de Engenharia de São Carlos, Universidade de São Paulo.

Este trabalho apresenta resultados de ensaios de fluência confinada e não-confinada de geotêxteis não-tecidos agulhados. Algumas dificuldades encontradas durante o desenvolvimento dos equipamentos utilizados para realizar esses ensaios em laboratório são também apresentadas e discutidas. A etapa de investigação sem confinamento envolveu a utilização de geotêxteis de poliéster e de polipropileno. Os resultados confirmaram o grande potencial desses materiais em apresentar fluência assim como a maior susceptibilidade dos geotêxteis de polipropileno. No caso de ensaios com confinamento, tentativas de se tracionar um geotêxtil de polipropileno entre duas camadas de solo revelaram grandes dificuldades para manter a carga aplicada constante ao longo do corpo de prova, em virtude da existência de atrito nas interfaces solo-geotêxtil. Ensaios alternativos retirando-se o solo e envolvendo-se o geotêxtil em uma membrana de látex lubrificada apresentaram bons resultados, comprovando a redução da fluência em relação aos ensaios não confinados e denotando tratar-se de uma solução viável para investigar o real papel do confinamento na fluência dos geotêxteis.

Palavras-chave: geotêxteis; fluência; confinamento; solo reforçado. 


\section{ABSTRACT}

COSTA, C. M. L. (1999). Creep of geotextiles. São Carlos, 1999. 97p. Dissertação (Mestrado) - Escola de Engenharia de São Carlos, Universidade de São Paulo.

This work presents results of confined and unconfined creep tests on nonwoven needle punched geotextiles. Withdraws found during the equipment development used to perform these tests are also highlighted and discussed. The unconfined tests encompassed the use of polyester and polypropylene geotextiles. Results confirm that these materials have a great potential to creep, being the polypropylene geotextiles the material with the greatest susceptibility. The confined tests where geotextile was placed between two soil layers revealed difficulties in keeping the applied load constant throughout the specimen due to soil-geotextile interface friction. Alternative tests performed without the soil and embedding the geotextile in a lubricated latex membrane showed good results, proving the decrease of creep in relation to unconfined tests. Thus, one can conclude that this is a viable solution towards the investigation of the real role that confinement plays in geotextile creep.

Keywords: geotextiles; creep; confinement; reinforced soil. 


\section{INTRODUÇÃO}

A utilização de geossintéticos em obras de engenharia civil data da década de 50 e constitui atualmente, prática generalizada e crescente no âmbito da geotecnia graças às diversas vantagens que estes materiais oferecem. Entre os aspectos que favorecem essa crescente utilização, incluem-se: versatilidade, fácil emprego, excelente desempenho e principalmente, o fato de proporcionarem baixo custo em comparação a soluções convencionais.

Dos inúmeros tipos de geossintéticos disponíveis, os geotêxteis foram os primeiros a serem empregados na geotecnia e constituem até hoje, os materiais mais utilizados dessa extensa família. Neste contexto, representam mantas têxteis capazes de desempenhar diferentes papéis em obras de engenharia. Qualquer que seja a função atribuída a estes materiais, espera-se, com exceção de obras temporárias, que os mesmos sejam capazes de desempenhar seu papel por um longo período de tempo.

A despeito das inúmeras vantagens que os geotêxteis apresentam, estes materiais, como tantos outros, apresentam fluência. No entanto, as questões relativas ao comportamento dos geotêxteis a longo prazo permaneceram adormecidas durante os primeiros anos de sua utilização, fato absolutamente natural dado o caráter inovador que esse tipo de construção incorporava.

Hoje, a crescente utilização e aceitação dos geotêxteis em obras geotécnicas, já não permite esse tipo de tratamento, especialmente, em casos onde as estruturas podem exigir um tempo de vida útil superior a 100 anos, como em algumas obras de contenção.

Embora não se tenha relatado na literatura casos de insucesso de obras em decorrência de fluência, esta adquire importância fundamental no dimensionamento de estruturas de solo reforçado com geotêxteis em virtude de três aspectos básicos: (i) ocorre à temperatura ambiente, (ii) pode provocar deformações excessivas e 
portanto inaceitáveis do ponto de vista de utilização da estrutura, principalmente dado o elevado tempo de vida útil desse tipo de obra, (iii) pode provocar ruptura, o que implica, na maioria das vezes, conseqüências catastróficas.

Esses efeitos potencialmente nocivos da fluência têm, sem dúvida, estimulado a comunidade científica na busca de um conhecimento mais profundo acerca desse mecanismo. Interesse esse, facilmente perceptível através das sessões exclusivamente dedicadas ao assunto nas mais recentes conferências internacionais sobre geossintéticos. A despeito desse interesse, ainda se percebe nitidamente uma grande ausência de informações sobre fluência de geotêxteis, principalmente com relação aos materiais disponíveis no mercado nacional, fato que se reflete diretamente no projeto, através dos altos valores dos coeficientes de segurança associados à fluência.

Com relação ao conhecimento acumulado até o presente momento, destaca-se o fato de algumas pesquisas (ex. MAcGOWN et al., 1982; WU \& HONG, 1994) terem demonstrado a redução da fluência de geotêxteis não-tecidos por efeito do confinamento, denotando a necessidade e a importância de estudos de fluência sob tais condições, já que os valores dos coeficientes de segurança encontrados na literatura provêm de ensaios sem confinamento. Sendo assim, pesquisas sobre fluência confinada podem contribuir para a adoção de critérios de projetos mais condizentes com a realidade, resultando em obras mais econômicas.

Motivado então, pela importância e atualidade do tema, o presente trabalho investiga alguns aspectos pertinentes à fluência de geotêxteis, apresentando e discutindo também, dificuldades associadas à construção de equipamentos para realizar ensaios de fluência em laboratório.

\section{Objetivos do trabal ho}

O trabalho ora apresentado teve por objetivos:

a) construir e calibrar equipamentos que permitam a realização de ensaios de fluência com e sem confinamento em laboratório; 
b) realizar ensaios de fluência não-confinada utilizando geotêxteis não-tecidos disponíveis no mercado nacional a fim de efetuar um reconhecimento geral do potencial de apresentar fluência desses materiais, uma vez que esse tipo de informação ainda não é apresentada nos catálogos dos fabricantes;

c) proceder a uma investigação preliminar do real efeito do confinamento na fluência de um geotêxtil de polipropileno não-tecido agulhado, disponível no mercado nacional.

\subsection{Organização do texto}

Além deste capítulo, a presente dissertação comporta mais 4 divisões. $\mathrm{O}$ capítulo 2 apresenta uma revisão da literatura relativa à fluência de geotêxteis, abordando inicialmente, alguns aspectos básicos desse tipo de geossintético, com ênfase em sua matéria-prima: os polímeros, já que indubitavelmente, afetam o comportamento dependente do tempo desses materiais. Em seguida, são mostrados, entre outros aspectos, os tipos de ensaios de fluência assim como os equipamentos já desenvolvidos para esse fim encontrados na literatura, discutindo-se ainda, os problemas inerentes a esse tipo de equipamento. Por fim, apresentam-se os reflexos da fluência no dimensionamento de estruturas de solo reforçado com geotêxteis, enfocando o caso de muros e taludes.

No capítulo 3, são mostrados os equipamentos e acessórios confeccionados para a realização dos ensaios de fluência previstos, relatando-se os principais empecilhos durante essa etapa do trabalho. Os geotêxteis e demais materiais utilizados nos ensaios são também identificados, expondo-se ainda, o programa de ensaios e a metodologia adotada.

No capítulo 4, estão dispostos os resultados dos ensaios de fluência confinada e não-confinada, procedendo-se sua discussão com relação ao tipo de polímero, efeito do confinamento, entre outros aspectos. Finalmente, o capítulo 5 expõe as principais conclusão obtidas no trabalho apresentando sugestões para pesquisas futuras. 


\section{REVISÃO BIBLIOGRÁFICA}

\section{Geotêxteis: Princípios gerais e aspectos relacionados à fluência}

Os geotêxteis podem ser definidos como produtos têxteis permeáveis utilizados na engenharia geotécnica (ASSOCIAÇÃO BRASILEIRA DE NORMAS TÉCNICAS - ABNT, NBR 12553, 1991). Esses materiais são constituídos por fibras obtidas através da fusão de polímeros, podendo desempenhar diversos papéis como parte integrante de um projeto de engenharia.

As funções frequientemente associadas a estes materiais são: drenagem (coleta e condução de um fluido ao longo do plano do geotêxtil), filtração (retenção de partículas de solo ou outros materiais possibilitando a passagem de um fluido através do geotêxtil), separação (evitando a mistura de materiais de naturezas diferentes) e reforço (melhoria do comportamento mecânico de uma estrutura geotécnica). A Figura 2.1 ilustra algumas das referidas aplicações: (a) separação, (b) filtração, (c) e (d) reforço.

(a)
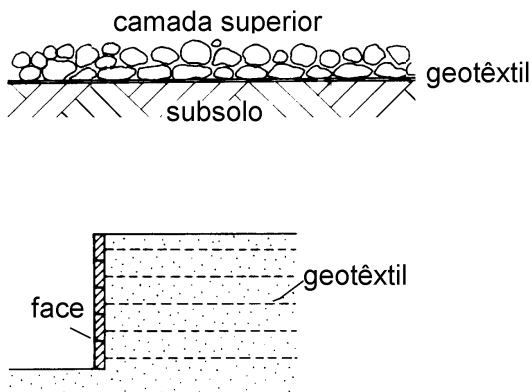

(c)

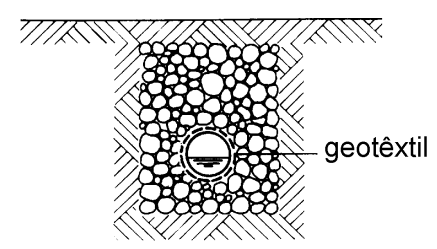

(b)

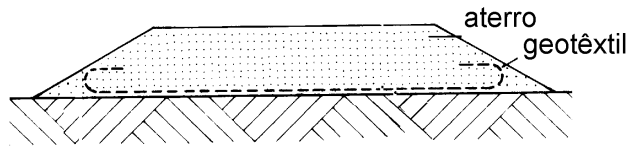

(d)

FIGURA 2.1 - Exemplos de aplicação de geotêxteis (a) separação de materiais distintos (b) envolvendo conduto utilizado para drenagem (c) estrutura de contenção (d) aterro reforçado (VAN ZANTEN, 1986). 
Alguns autores (ex. MSOUTI et al., 1997) destacam ainda, a utilização de geotêxteis como elemento de proteção, no caso, por exemplo, em que se coloca este material entre uma geomembrana e uma camada de solo com o desígnio de evitar perfurações na mesma. Quando impregnados por betume, os geotêxteis podem funcionar ainda como uma barreira impermeável a líquidos e/ou vapores (KOERNER, 1994). Na prática, entretanto, é comum observar geotêxteis desempenhando diferentes funções simultaneamente.

Como reforço, o principal papel dos geotêxteis consiste em proporcionar resistência à tração ao solo que naturalmente, possui alta resistência à compressão e baixa resistência à tração (JOHN, 1987). A inclusão dessas mantas em uma massa de solo, melhora então, o comportamento mecânico do maciço, aumentando sua resistência e diminuindo sua compressibilidade, acarretando portanto, obras mais econômicas e com uma geometria mais ousada (PALMEIRA, 1991). Entre os possíveis exemplos de obras nas quais os geotêxteis podem ser empregados com função de reforço, incluem-se aterros sobre solos moles, fundações (melhoria da capacidade de carga) e estruturas de contenção.

Considerando os tipos de aplicação dos geotêxteis, apenas sua utilização como reforço, pode exigir que os mesmos permaneçam tracionados por um longo período de tempo. Assim, para esse tipo de aplicação, a possibilidade de fluência e os reflexos desse mecanismo assumem grande importância no dimensionamento de obras geotécnicas.

Com relação à fluência, alguns autores (ex. DEN HOEDT, 1988; JEWELL \& GREENWOOD, 1988; CAZZUFFI et al., 1997) consideram que tanto o processo de fabricação (geotêxteis tecidos, não-tecidos, etc), como as características do polímero influenciam esse mecanismo. Essa questão, no entanto parece ser afetada principalmente pelo tipo de polímero, como destaca ABRAMENTO (1995). De qualquer forma, estes dois aspectos serão abordados nos itens seguintes, com o intuito de fundamentar alguns conceitos antes de se discutir propriamente a fluência dos geotêxteis (item 2.2). 


\subsubsection{Polímeros}

\subsubsection{Generalidades}

No início do século $\mathrm{XX}$, cientistas descobriram que alguns materiais produzidos pela química da época podiam resultar no encadeamento de $10.000 \mathrm{ou}$ mais átomos de carbono com repetição de pequenas unidades estruturais, sendo então denominados polímeros (MANO, 1991). O termo "polímero" porém, é mais antigo e originou-se do grego ( "poli-muitas, mero-partes").

Atualmente, entende-se por polímeros, moléculas relativamente grandes, de pesos moleculares da ordem de $10^{3}$ a $10^{6}$, em cuja estrutura se encontram unidades químicas simples e repetidas, conhecidas como meros ou monômeros (MANO, 1985).

Os polímeros constituem a matéria-prima para a fabricação dos geotêxteis e sua formação acontece através de uma reação química denominada polimerização, na qual "n" moléculas de monômero sofrem um processo de ligação, dando origem a macromoléculas. O número de meros "n" que compõe determinada cadeia polimérica é conhecido por grau de polimerização.

Desde o advento de sua descoberta até o presente momento, técnicas e aplicações envolvendo os polímeros sintéticos têm apresentado grande desenvolvimento. Atualmente, estes materiais desempenham importante papel em diversos setores da sociedade, encontrando aplicação cada vez mais crescente na engenharia geotécnica, através dos geossintéticos.

\subsubsection{Classificação dos polímeros}

Inúmeras classificações são plausíveis quanto se trata de agrupar polímeros, principalmente devido à diversidade que o tema envolve. Segundo MANO (1985), os polímeros podem ser identificados de acordo com sua estrutura química em poliamidas, poliésteres, poliéteres, entre outros. Além desse aspecto, os polímeros ainda podem ser classificados segundo o método de preparação, as características tecnológicas e o comportamento mecânico. 
- Método de preparação

O processo de preparação pode resultar em polímeros de adição ou de condensação. Na reação de adição, ocorre quebra de ligações duplas presente no monômero (ex. $\mathrm{C}=\mathrm{C}$ ) para que ocorra a ligação entre moléculas, o processo acontece sem a eliminação de substâncias como $\mathrm{H}_{2} \mathrm{O}, \mathrm{HCl}$ e $\mathrm{KCl}$. Um exemplo de polímero que resulta desse processo é o polipropileno, como pode ser observado na Figura 2.2.

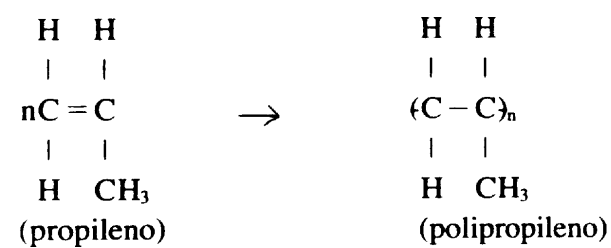

FIGURA 2.2 - Formação do polipropileno por adição (ROCHA, 1985)

A reação de condensação, ao contrário, caracteriza-se pelo fato de haver eliminação de pequenas moléculas durante a polimerização. O poliéster resulta desse tipo de reação como mostra a Figura 2.3.

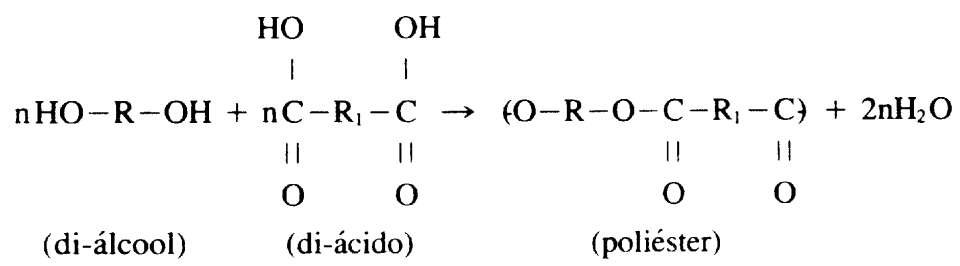

FIGURA 2.3 - Formação do poliéster por condensação (ROCHA, 1985)

- Características tecnológicas

Com relação a esse aspecto, os polímeros podem ser classificados de acordo com suas características de fusibilidade e de funcionalidade do monômero, em termoplásticos e termorrígidos. A funcionalidade do monômero pode ser entendida como sua capacidade de produzir ligações covalentes com outras moléculas. 
Considera-se termoplásticos, os polímeros que sofrem fusão quando aquecidos e solidificação quando resfriados, enquanto os termorrígidos são infusíveis (NICHOLSON,1991; MANO, 1991).

Com relação a essa questão, ROCHA (1985) ressalta que os termoplásticos são formados por monômeros bifuncionais, dando origem a polímeros cuja estrutura é constituída por macromoléculas dispostas linearmente. Em oposição, polímeros de estrutura tridimensional apresentam-se como termorrígidos. A Figura 2.4 ilustra o tipo de funcionalidade do monômero.

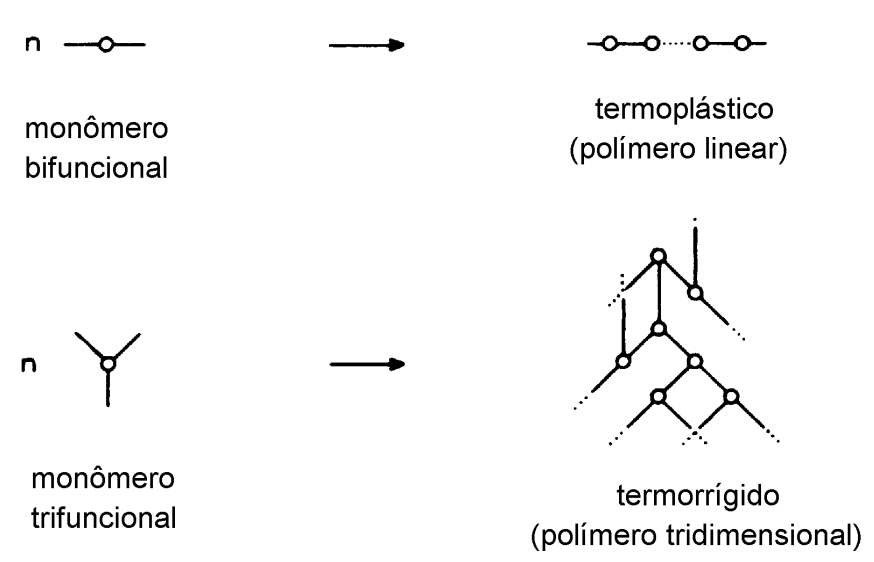

FIGURA 2.4 - Representação esquemática de termoplásticos e termorrígidos (ROCHA, 1985)

- Comportamento mecânico

Neste contexto, é possível identificar três grandes grupos de polímeros: borrachas ou elastômeros, plásticos e fibras.

Os elastômeros constituem materiais que apresentam elasticidade elevada à temperatura ambiente, ao passo que os plásticos caracterizam-se pelo fato de embora sólidos à temperatura ambiente, podem ser moldados sob a ação de calor e/ou pressão.

As fibras apresentam elevada razão entre o comprimento e as demais dimensões. Para o caso de seção circular, as mesmas são caracterizadas por uma relação comprimento - diâmetro no mínimo igual a 100 (ROSEN, 1982).

As fibras constituem o elemento base para a fabricação dos geotêxteis, sendo neste caso, obtidas pela extrusão de polímero fundido através dos orifícios de uma placa (fieira). Para a maioria das fibras utilizadas em geotêxteis, os filamentos 
viscosos que atravessam a fieira são solidificados por resfriamento (KOERNER, 1994). Após a extrusão, os filamentos podem sofrer um processo de estiramento a fim de promover uma melhoria de suas propriedades mecânicas ou esse processo pode-se seguir como uma etapa adicional após os filamentos serem bobinados (MARK et al., 1986).

A Figura 2.5 apresenta um esquema geral do processo utilizado para a obtenção de fibras. A presença de um filtro antes da massa polimérica atravessar a fieira tem como objetivo reter, por exemplo, partículas sólidas que possam estar presentes no material fundido.

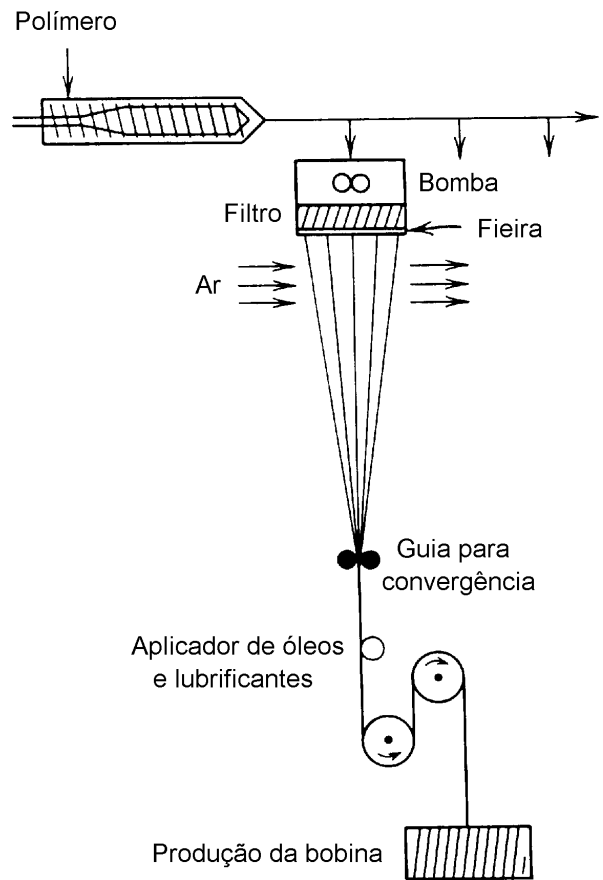

FIGURA 2.5 - Processo de fabricação de fibras (MARK et al., 1986)

2.1.1.3 Estrutura macromolecular dos polímeros

A estrutura macromolecular dos polímeros influencia, entre outros aspectos, a durabilidade e a fluência das fibras utilizadas na confecção dos geotêxteis, afetando consequentemente, o desempenho dos mesmos, como será visto em seguida.

Com relação a esse aspecto, os polímeros podem se encontrar no estado amorfo ou cristalino. Na verdade, nos polímeros denominados semi-cristalinos 
ambos estados convivem em regiões distintas, ocorrendo raramente, casos de polímeros $100 \%$ cristalinos (MANO, 1985).

Nas regiões cristalinas, as moléculas encontram-se organizadas apresentando uma distribuição regular, ao passo que nas regiões amorfas, as cadeias poliméricas ou segmentos das mesmas não estão ordenados, possuindo uma distribuição aleatória (BILLMEYER, 1984; COOKE \& REBENFELD, 1988). A Figura 2.6 apresenta uma representação esquemática dessas regiões.

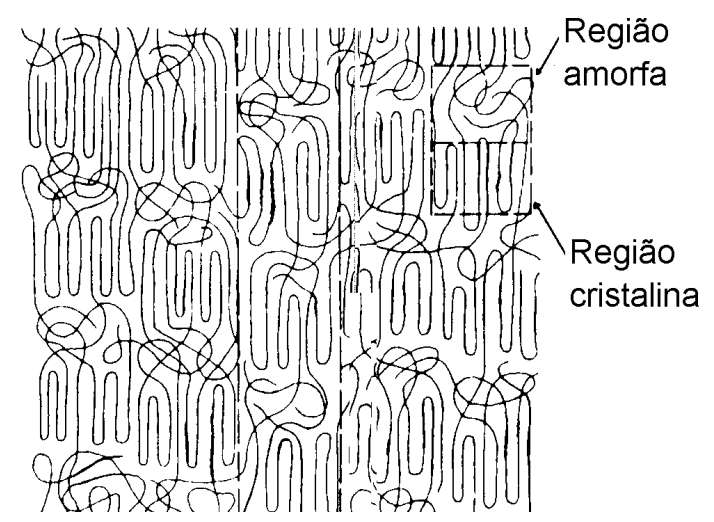

FIGURA 2.6 - Regiões amorfas e cristalinas (VAN ZANTEN, 1986)

Abaixo de uma determinada temperatura denominada de transição vítrea $\left(T_{g}\right)$, as regiões amorfas apresentam-se num estado vítreo. Nesta condição, não existe energia suficiente para permitir a movimentação relativa das cadeias poliméricas, assemelhando-se a uma estrutura congelada. Quando a temperatura de transição vítrea é atingida, as regiões amorfas vão então, adquirindo mobilidade. Caso se prossiga com o aquecimento pode-se atingir uma temperatura denominada de fusão cristalina $\left(\mathrm{T}_{\mathrm{m}}\right)$, a partir da qual o polímero apresentar-se-á num estado líquido viscoso (DANIELS, 1989).

Muitas propriedades importantes das fibras estão associadas às regiões amorfas, entre as quais, a capacidade de absorção de umidade e a resiliência. Já a cristalinidade, interfere em aspectos como resistência à tração e rigidez das fibras que aumentam com um acréscimo da mesma (COOKE \& REBENFELD, 1988). O comportamento tensão-deformação, no entanto, é quase que exclusivamente determinado pela deformação das regiões amorfas (DEN HOEDT, 1986). O aumento 
da cristalinidade conduz ainda, a uma maior resistência ao calor e a uma resistência química mais elevada (KOERNER, 1994).

\subsubsection{Polímeros utilizados na fabricação de geotêxteis}

Os polímeros utilizados na confecção das fibras de geotêxteis são termoplásticos e semi-cristalinos, em ordem crescente de utilização, os principais tipos são: poliamida (PA), polietileno (PE), poliéster (PET) e polipropileno (PP) (HORROCKS \& D'SOUZA, 1992; KOERNER, 1994). A Figura 2.7 expõe a estrutura dos monômeros dos referidos polímeros, enquanto a Tabela 2.1 apresenta algumas de suas propriedades básicas.<smiles>CC(C)C1CCC1CC1CC1</smiles>

a) Polipropileno (PP)<smiles>COCCCO[C@H](O)c1ccc(C2COC2)cc1</smiles>

c) Poliéster (PET)<smiles>C1CC2CC1CC2C1CC1</smiles>

b) Polietileno (PE)<smiles>CN1CCCCCC1[18O]C1CO1</smiles>

d) Poliamida (PA)

FIGURA 2.7 - Estrutura química de alguns monômeros (ABRAMENTO, 1995)

TABELA 2.1 - Propriedades básicas de alguns polímeros (VAN ZANTEN, 1986)

\begin{tabular}{l|c|c|c|c|c|c}
\hline Propriedade & $\begin{array}{c}\text { PA } \\
\text { nylon 6 }\end{array}$ & $\begin{array}{c}\text { PA } \\
\text { nylon 6.6 }\end{array}$ & PET & PP & LDPE & HDPE \\
\hline Densidade $\left(\mathrm{kg} / \mathrm{m}^{3}\right)$ & 1140 & 1140 & 1380 & $900-910$ & $920-930$ & $940-960$ \\
Cristalinidade $(\%)$ & 60 & 60 & $30-40$ & $60-70$ & $40-55$ & $60-80$ \\
$\mathrm{~T}_{\mathrm{g}}\left({ }^{0} \mathrm{C}\right)$ & $30-60$ & $30-60$ & 75 & $-15 / 10$ & -100 & -100 \\
$\mathrm{~T}_{\mathrm{m}}\left({ }^{0} \mathrm{C}\right)$ & $215-220$ & 250 & $250-260$ & $160-165$ & $110-120$ & $125-135$ \\
\hline
\end{tabular}

LDPE - polietileno de baixa densidade; HDPE - polietileno de alta densidade.

O comportamento mecânico das fibras utilizadas em geotêxteis pode ser observado na Figura 2.8. Como se pode notar, o poliéster proporciona maior resistência à tração e menor deformação na ruptura do que os demais polímeros, sendo as menores resistências associadas ao polietileno e ao polipropileno. 
Segundo COOKE \& REBENFELD (1988) a maior resistência das fibras de poliéster e nylon deve-se às fortes ligações coesivas intermoleculares, sendo as fracas ligações de Van der Waal responsáveis pelo comportamento das poliolefinas (PP e $\mathrm{PE})$.

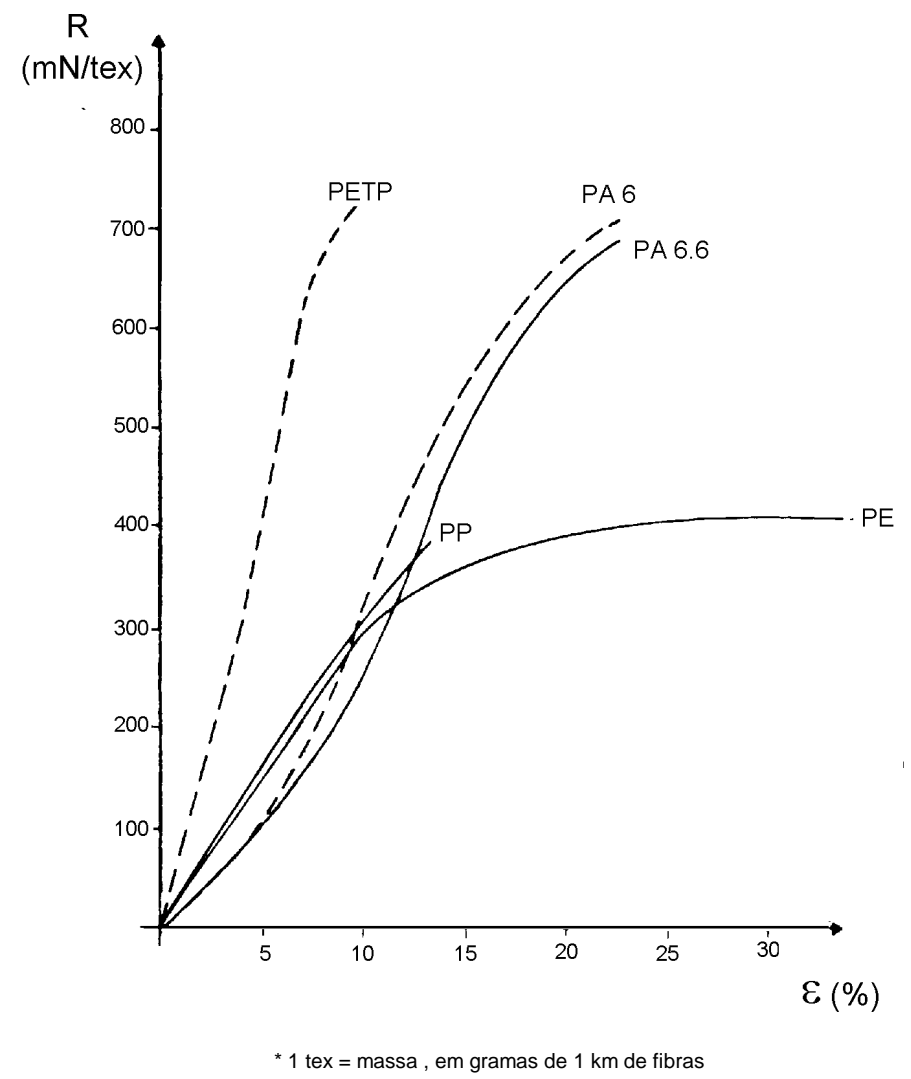

FIGURA 2.8 - Curva carga x deformação para cinco fibras a $20^{\circ} \mathrm{C}$ (VAN ZANTEN, 1986)

Apesar do melhor desempenho mecânico das fibras de poliéster, alguns outros aspectos podem limitar sua utilização, como por exemplo, o custo. Nenhum polímero, no entanto, possui características ideais quando se considera ainda aspectos como durabilidade e fluência. Dependendo do mecanismo considerado, determinado polímero irá apresentar-se mais ou menos vulnerável. Algumas características básicas desses polímeros são apresentadas a seguir.

- Polietileno (PE)

Constitui o polímero orgânico mais simples e possui a estrutura química menos reativa de todos os termoplásticos comercializados. Características como 
processamento fácil, baixo custo e propriedades físicas aceitáveis justificam sua utilização na fabricação de geotêxteis (CASSIDY et al., 1992). É geralmente resistente a ataque químico mas está sujeito a termo e foto-oxidação na presença de radiação ultravioleta, apresentando acentuada sensibilidade à fluência (COOKE \& REBENFELD, 1988).

- Polipropileno

Este polímero está presente em cerca de $83 \%$ das fibras de geotêxteis (KOERNER, 1994). Este sucesso, de acordo com HORROCKS \& D'SOUZA (1992), deve-se a suas propriedades mecânicas aceitáveis, inércia química e custo relativamente baixo. Os maiores problemas associados a este polímero estão relacionados à oxidação e à fluência.

- Poliamida (PA)

Os tipos mais importantes usados na fabricação dos geotêxteis são o nylon 6 e o nylon 6.6. As propriedades químicas desses dois tipos de poliamida são similares, sendo ambos resistentes a ataque químico.

As fibras de nylon são mais resistentes à foto-oxidação e termo-oxidação do que as fibras de PP e PE, apresentando resistência à hidrólise em ambientes neutros e alcalinos. Suas propriedades mecânicas, no entanto, são significativamente diferentes em ambiente seco ou úmido, denotando sensibilidade à água (COOKE \& REBENFELD, 1988).

- Poliéster (PET)

Segundo KOERNER (1994) cerca de 14\% das fibras utilizadas em geotêxteis são de poliéster. Entre os fatores que justificam esse uso estão principalmente suas propriedades mecânicas, como a elevada resistência à tração. O grande inconveniente associado às fibras de poliéster parece ser, de acordo com HORROCKS \& D’SOUZA (1992), a sensibilidade à hidrólise em ambientes alcalinos. Este polímero 
possui pequena susceptibilidade à fluência (ROCHA, 1985) e moderada estabilidade à radiação ultravioleta.

\subsubsection{Tipos de Geotêxteis}

Apesar da grande diversidade de geotêxteis, pode-se agrupá-los basicamente em duas grandes classes: geotêxteis tecidos e não-tecidos. Alguns autores (ex. JOHN, 1987; KOERNER, 1994) destacam ainda a existência de uma terceira classe, constituída por geotêxteis tricotados que são porém, menos utilizados. Neste caso, a interligação das unidades de fiação acontece através de uma série repetida de laços (Figura 2.9).

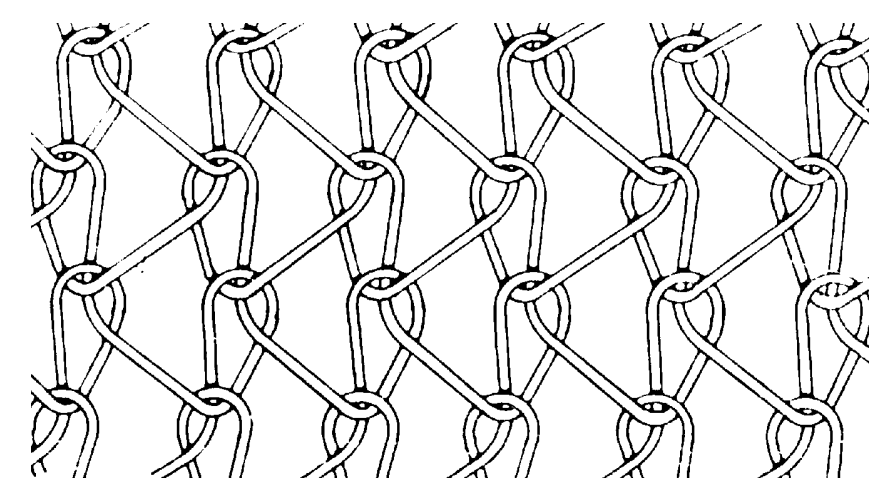

FIGURA 2.9 - Estrutura de um geotêxtil tricotado (JOHN, 1987)

\subsubsection{Geotêxteis Tecidos}

Os geotêxteis tecidos constituem materiais obtidos através do entrelaçamento de fios, filamentos ou outros componentes, segundo direções preferenciais, denominadas trama e urdume (ABNT - NBR 12553, 1991). A trama corresponde aos fios dispostos transversalmente à direção de fabricação do geotêxtil, enquanto os fios dispostos longitudinalmente a essa direção correspondem ao urdume.

No caso de geotêxteis tecidos, quatro tipos principais de fibras são utilizadas: monofilamentos, multifilamentos, laminetes e fibrilas (BHATIA \& SMITH, 1996). Os monofilamentos podem atingir centenas ou milhares de metros e constituem fibras individuais fabricadas com seção transversal circular ou oval (Figura 2.10a), já os multifilamentos, como o próprio nome sugere, são formados pela associação de 
diversos filamentos (Figura 2.10b). Quando o produto extrusado apresenta-se lamelar, pode-se cortá-lo em fitas estreitas dando origem aos laminetes (Figura 2.10c) ou cortá-lo descontinuamente em pequenos elementos que quando unidos, constituem as fibrilas (Figura 2.10d).

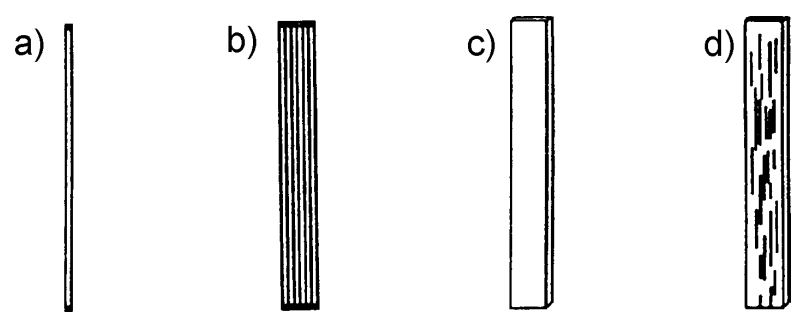

FIGURA 2.10 - Tipos de fibras (BHATIA \& SMITH, 1996).

Convém salientar que as fibras acima descritas constituem tipos básicos, podendo-se encontrar ainda, algumas variações a partir das mesmas. A Figura 2.11 apresenta regiões de geotêxteis tecidos fabricados com algumas das fibras anteriormente mencionadas.
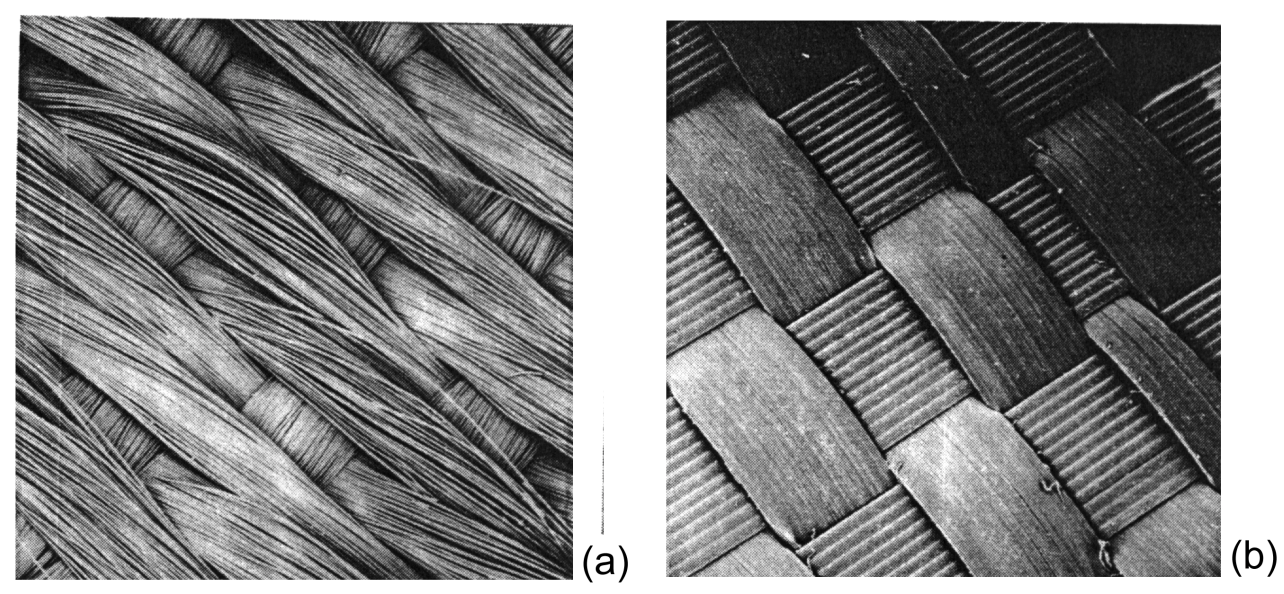

FIGURA 2.11 - Geotêxteis tecidos (ampliação de 8x) (a) multifilamentos (b) laminetes (BHATIA \& SMITH, 1996).

\subsubsection{Geotêxteis não-tecidos}

Estes materiais são compostos por fibras ou filamentos distribuídos aleatoriamente e interligados por processos mecânicos, térmicos e/ou químicos (ABNT - NBR 12553, 1991). Dois tipos de fibras podem ser utilizadas na confecção 
de geotêxteis não-tecidos, as fibras cortadas e os filamentos contínuos, ambos com seção transversal circular. A diferença consiste no comprimento associado a cada um desses elementos, filamentos contínuos possuem grande extensão, ao passo que as fibras apresentam comprimento reduzido, cerca de 25 a $100 \mathrm{~mm}$ (BHATIA \& SMITH, 1996).

A produção de geotêxteis não-tecidos envolve geralmente, a utilização de um processo de fabricação contínuo denominado "spunbonding" que abrange desde a produção das fibras até a obtenção do produto final, ou seja, as mantas já dispostas em bobinas. A Figura 2.12 apresenta um esquema das etapas básicas associadas a esse processo. Com relação ao tipo de ligação das fibras, pode-se distinguir geotêxteis agulhados, termoligados e resinados.

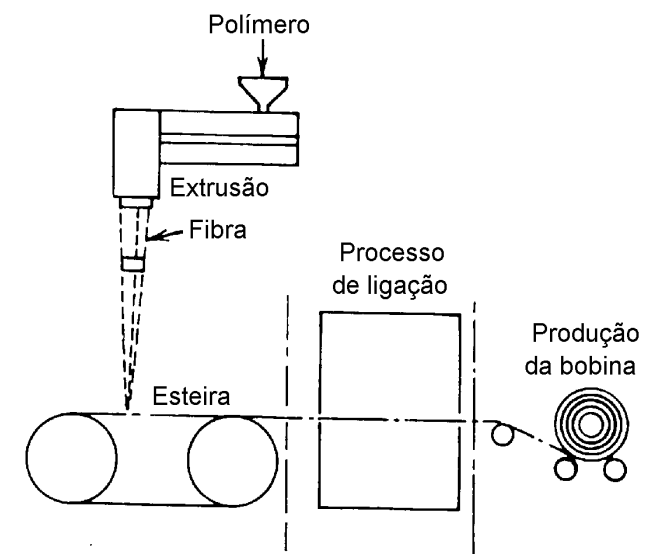

FIGURA 2.12 - Processo de fabricação "Spunbonding” (MARK et al., 1986).

No processo mecânico de agulhagem, as fibras dispostas na esteira rolante passam sob uma prancha constituída por uma série de agulhas dentadas. A ligação acontece mediante a penetração das agulhas, repetidas vezes, em toda profundidade do material a fim de provocar o entrelaçamento das fibras (Figura 2.13a). A espessura associada a este tipo de geotêxtil varia geralmente, de 2 a $5 \mathrm{~mm}$ (JOHN, 1987).

Nos geotêxteis termoligados (Figura 2.13b), a ligação acontece através da fusão parcial das fibras. Processo que pode provocar a ligação tanto de alguns pontos, como também de regiões mais extensas da manta. Esse tipo de geotêxtil normalmente apresenta espessura reduzida, variando de 0,5 a $1 \mathrm{~mm}$ (JOHN, 1987). 

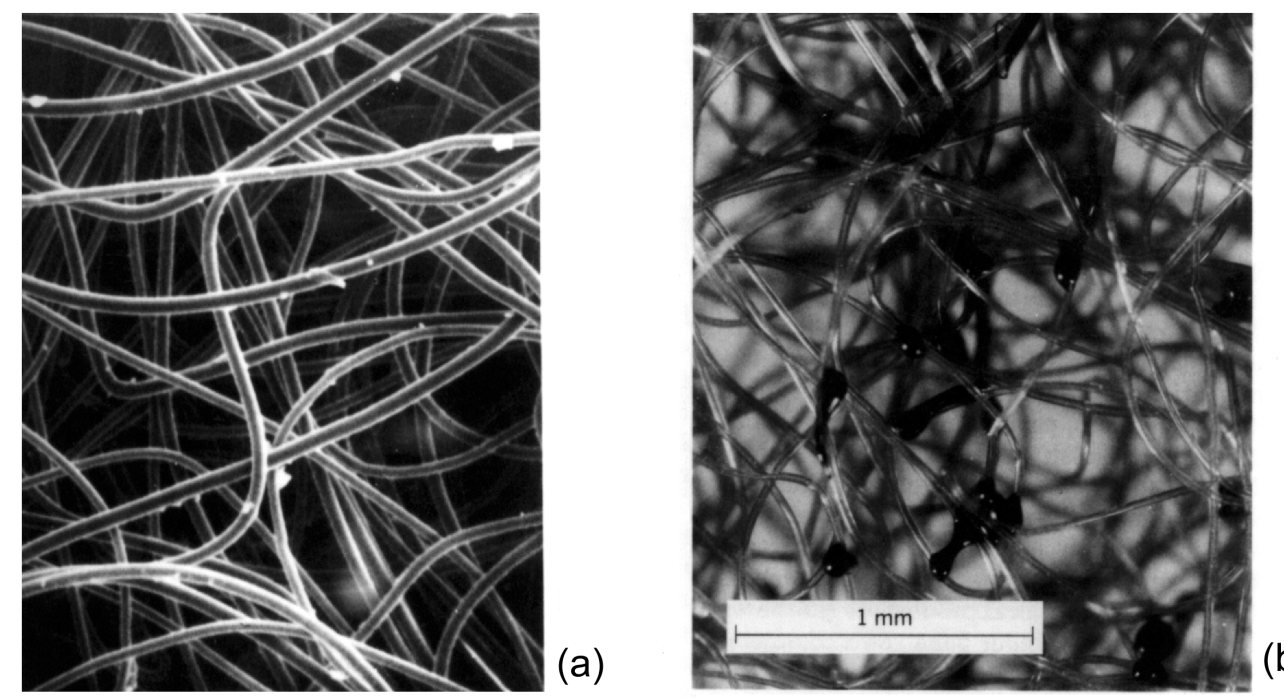

(b)

FIGURA 2.13 - Estruturas não-tecidas (a) agulhada (b) termoligada (MARK et al., 1986)

No caso de geotêxteis resinados, a ligação ocorre através de alguma substância química, como por exemplo, resina acrílica aplicada por imersão ou pulverização.

\section{Fluência de Geotêxteis}

A grande maioria dos dados disponíveis relativos a fluência de geotêxteis provém de ensaios de laboratório, inicialmente realizados com amostras livres da ação de pressões confinantes. A tendência atual, no entanto, para alguns tipos de geotêxteis, tem sido a de incorporar essa variável aos ensaios. Estudos através da observação de obras instrumentadas e de modelos de estruturas de solo reforçado devem-se somar ainda nos próximos anos, aos ensaios de laboratório na busca de respostas sobre o comportamento de fluência dos geotêxteis.

\subsubsection{Conceitos básicos}

A fluência (creep) reflete o comportamento elasto-viscoplástico dos geossintéticos e representa a deformação ao longo do tempo que estes materiais sofrem sob carregamento constante (CAZZUFFI et al., 1997). Esse processo, como já mencionado, possibilita uma eventual ruptura que, segundo JEWELL \& 
GREENWOOD (1988), pode ocorrer por exemplo, por quebra de ligações moleculares em virtude de um comprimento crítico das cadeias poliméricas.

Entre os fatores que podem influenciar a fluência de geotêxteis destacam-se: o nível de carregamento (um aumento da carga aplicada tende a acelerar o processo), o tipo de polímero, a temperatura e a presença de confinamento.

Assim como para os solos e para os materiais metálicos, até três fases distintas podem ser evidenciadas quando se trata da fluência de geotêxteis: creep primário, secundário e terciário (CAZZUFFI et al., 1997; MIKI et al., 1990). A Figura 2.14 identifica as fases mencionadas em termos da deformação e da taxa na qual a mesma ocorre ao longo do tempo.

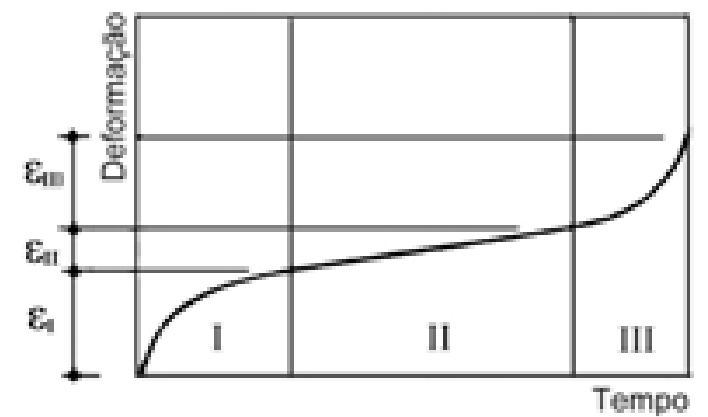

(a)

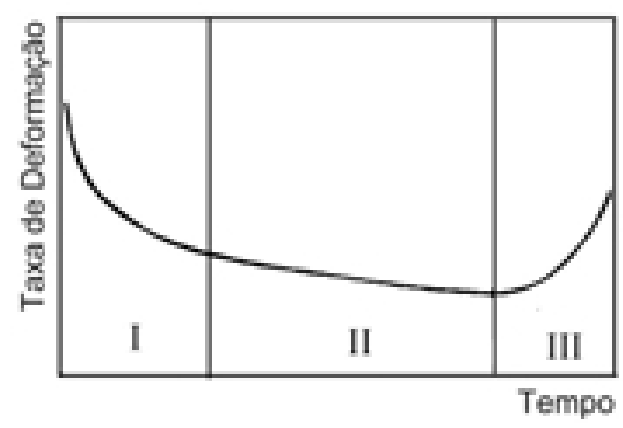

(b)

FIGURA 2.14 - Possíveis fases de fluência apresentadas por geotêxteis (a) deformação x tempo (b) taxa de deformação x tempo (CAZZUFFI et al., 1997).

No estágio de fluência primária, as deformações se desenvolvem rapidamente, ao passo que a taxa de deformação decresce. Após esse período, tem-se início a fase de fluência secundária na qual a taxa de deformação torna-se praticamente constante, atingindo um valor mínimo, a partir do qual começa a aumentar (creep terciário) culminando então, com a ruptura. Em qualquer tempo (t) a deformação total $(\varepsilon)$ pode ser obtida através da expressão (2.1), sendo a deformação instantânea ou imediata composta por duas parcelas, uma recuperável após o descarregamento (deformação elástica) e outra irrecuperável (deformação plástica).

$\varepsilon(\mathrm{t})=\varepsilon_{0}+\varepsilon_{\mathrm{I}}+\varepsilon_{\mathrm{II}}+\varepsilon_{\mathrm{III}}$ 
onde,

$\varepsilon_{0}$ - deformação imediata;

$\varepsilon_{\mathrm{I}}, \varepsilon_{\mathrm{II}}, \varepsilon_{\mathrm{III}}-$ deformação primária, secundária e terciária, respectivamente.

Dependendo do tipo de geotêxtil, alguma fase característica do comportamento de fluência pode não ficar evidenciada, havendo então a predominância de determinado estágio, como pode ser observado nas curvas apresentadas na figura 2.15. Segundo MÜLLER-ROCHHOLZ \& KOSLOWSKI* apud CAZZUFFI et al. (1997), o creep terciário é comum para o polietileno e para o polipropileno, já para o poliéster esta fase não fica caracterizada considerando os níveis de carga e as temperaturas geralmente utilizados nos ensaios.

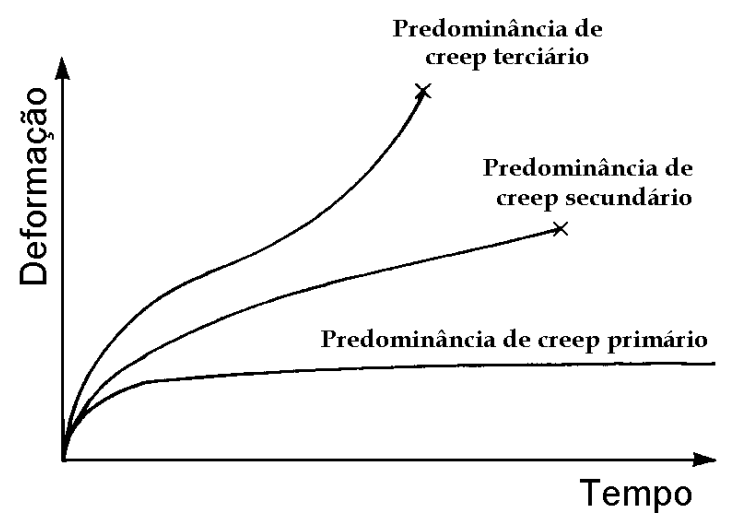

FIGURA 2.15 - Predominância de algum estágio de fluência (MIKI et al., 1990).

\subsection{2 - Ensaios de fluência}

\subsubsection{Metodologia de ensaio}

Os ensaios de fluência podem ser divididos em confinados e não-confinados, dependendo do corpo de prova estar ou não, submetido ao efeito de tensões confinantes durante a sua realização. Lamentavelmente, ainda não existe norma

\footnotetext{
* MÜLLER-ROCHHOLZ, J.; KOSLOWSKI, C. (1996). Creep prediction. In: European Geosynthetics Conference, 1. Proceedings. The Netherland. p.1027-1030 apud CAZZUFFI et al. (1997). European experimental approach to the tensile creep behaviour of high-strenght geosynthetics. In: Geosynthetics '97. Proceedings. California. v.1, p.253-266.
} 
brasileira disponível para a elaboração desses ensaios, bem como nenhuma norma em nível mundial estabelece uma técnica para ensaios confinados. Estes últimos baseiam-se geralmente, nas normas relativas a fluência não-confinada (ex. AMERICAN SOCIETY FOR TESTING AND MATERIALS - ASTM D5262, 1994).

Nestes ensaios, corpos de prova, geralmente de $200 \mathrm{~mm}$ de largura por 100 mm de comprimento (fluência de faixa larga), são submetidos a carregamentos constantes correspondentes a uma parcela da resistência à tração, registrando-se as deformações em tempos pré-estabelecidos.

Os ensaios correspondentes ao maiores níveis de carregamento, em geral, atingem 1000 horas, enquanto os efetuados com menores cargas podem atingir mais de 10.000 horas (MURRAY \& MAcGOWN, 1988). Os resultados obtidos, podem ser apresentados de diversas formas, cada uma facilitando a análise dos resultados sob determinado ponto de vista, como pode ser observado nas Figuras 2.16, 2.17 e 2.18 .

As curvas deformação x tempo (este último na escala logarítmica ou não) constituem a forma mais tradicional de apresentação dos resultados e possibilitam uma rápida idéia da magnitude das deformações em cada nível de carregamento (Figura 2.16).

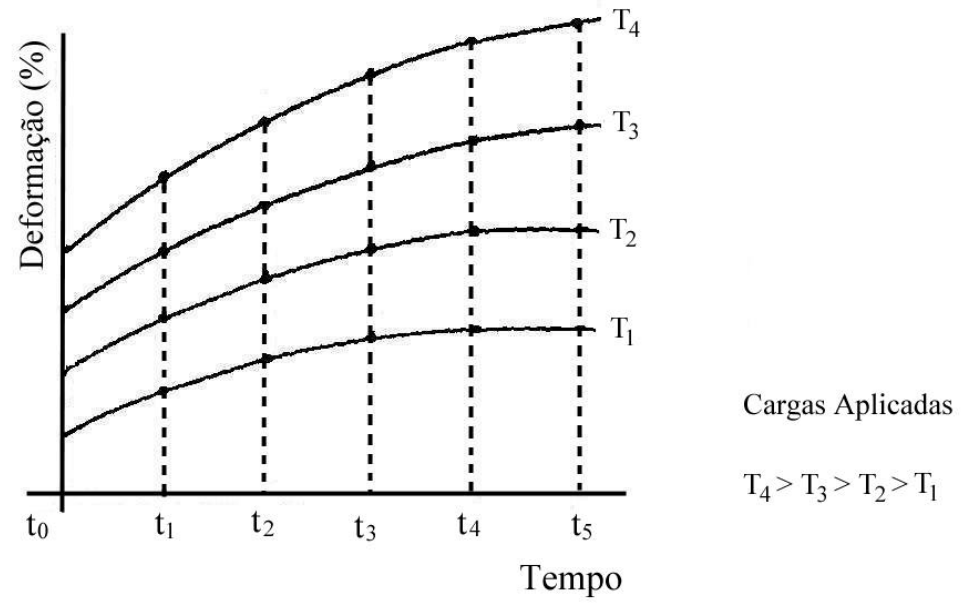

FIGURA 2.16 - Curvas deformação x tempo em ensaios de fluência (ALLEN, 1991).

As curvas isócronas (Figura 2.17) revelam as deformações, para um mesmo tempo, considerando diferentes níveis de carga. Por último, as curvas Sherby-Dorn apresentam o logaritmo da taxa de deformação x deformação, mostrando claramente 
quando material se aproxima da ruptura, linha de instabilidade mostrada na Figura 2.17 .

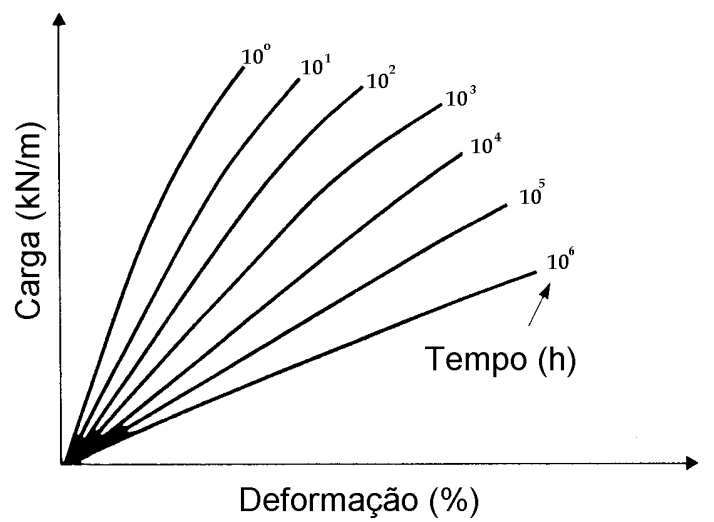

FIGURA 2.17 - Curvas isócronas carga-deformação (MURRAY \& MAcGOWN, 1988).

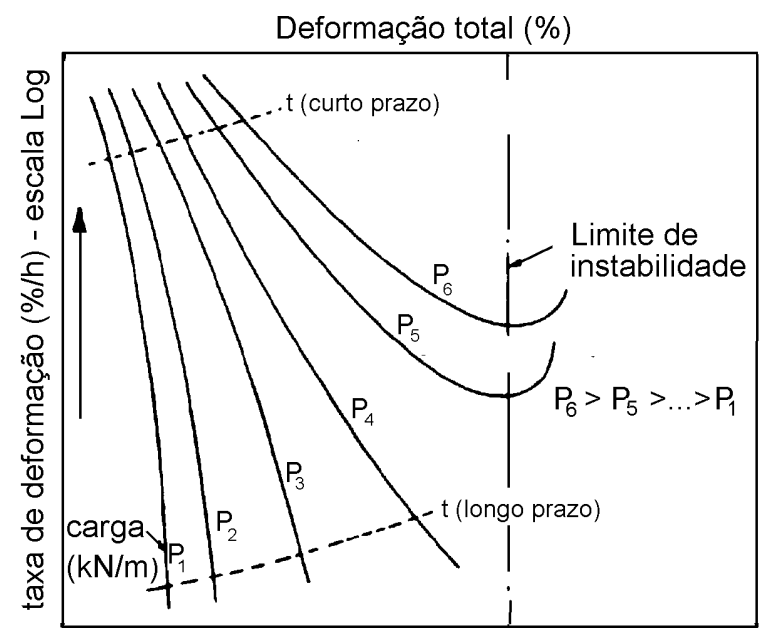

FIGURA 2.18 - Curvas Sherby-Dorn (MAcGOWN et al., 1986).

O tempo necessário para a realização de ensaios constitui obviamente, um grande empecilho no desenvolvimento de estudos de fluência. Assim sendo, torna-se necessário proceder a algum tipo de extrapolação do dados, a fim de considerar o comportamento do material durante o tempo de vida útil de uma determinada obra. Neste sentido, pode-se proceder a uma extrapolação meramente visual ou utilizar expressões matemáticas como equações exponenciais ou logarítmicas. Modelos reológicos, alguns tradicionalmente usados para descrever o comportamento mecânico de polímeros, também podem ser usados como ferramenta para extrapolação dos dados de ensaios. 
Dois modelos viscoelásticos são geralmente empregados, o de Boltzmann e o de Burger (MSOUTI et al., 1997). No primeiro caso, pode-se obter uma boa aproximação do regime de fluência primária, já a utilização do modelo de Burger permite simular dois estágios de fluência: primária e secundária. A Figura 2.19 apresenta o esquema representativo desses modelos.

(a)

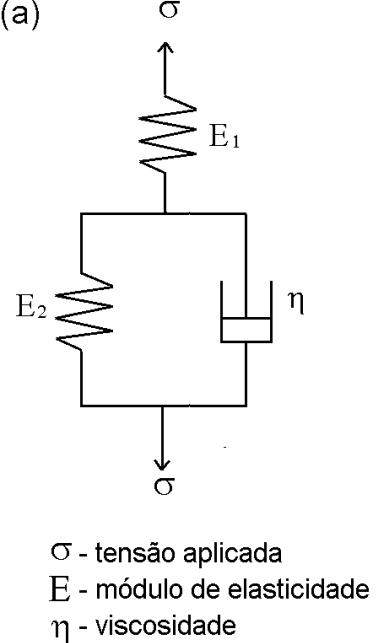

(b) $\sigma$

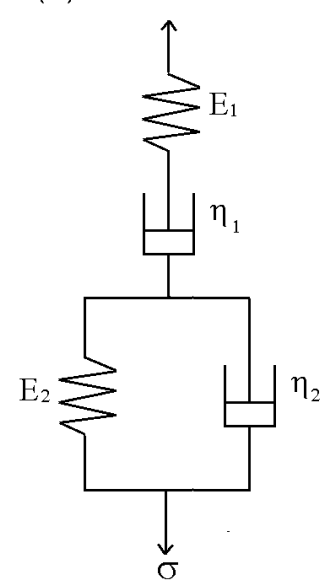

FIGURA 2.19 - (a) Modelo de Boltzmann (b) modelo de Burger.

As equações (2.2) e (2.3) constituem a solução do modelo de Boltzmann e de Burger, respectivamente, apresentando a deformação total ao longo do tempo, $\varepsilon(\mathrm{t})$, em função da tensão aplicada $(\sigma)$ e das características do material.

$$
\begin{aligned}
& \varepsilon(t)=\sigma\left(\frac{\left(E_{1}+E_{2}\right)}{E_{1} \cdot E_{2}}-\frac{e^{\frac{E_{2} \cdot t}{\eta}}}{E_{2}}\right) \\
& \varepsilon(t)=\frac{\sigma}{E_{1}}+\left(\frac{\sigma}{\eta_{1}} \cdot t\right)+\left(\frac{\sigma}{E_{2}} \cdot\left(1-e^{\frac{E_{2} \cdot t}{\eta_{2}}}\right)\right)
\end{aligned}
$$

SOONG \& KOERNER (1998) propuseram para geossintéticos, a utilização de um modelo viscoelástico constituído por um elemento de mola associado em série com diversas unidades de Kelvin (Boltzmann a " $n$ " elementos) cujo esquema 
representativo pode ser observado na Figura 2.20. Resultados de ensaios de fluência com diferentes tipos de geossintéticos, incluindo geotêxteis, foram analisados pelos autores e em todos os casos, o modelo se mostrou capaz de simular adequadamente, o comportamento desses materiais. A expressão (2.4) representa a equação constitutiva desse modelo.

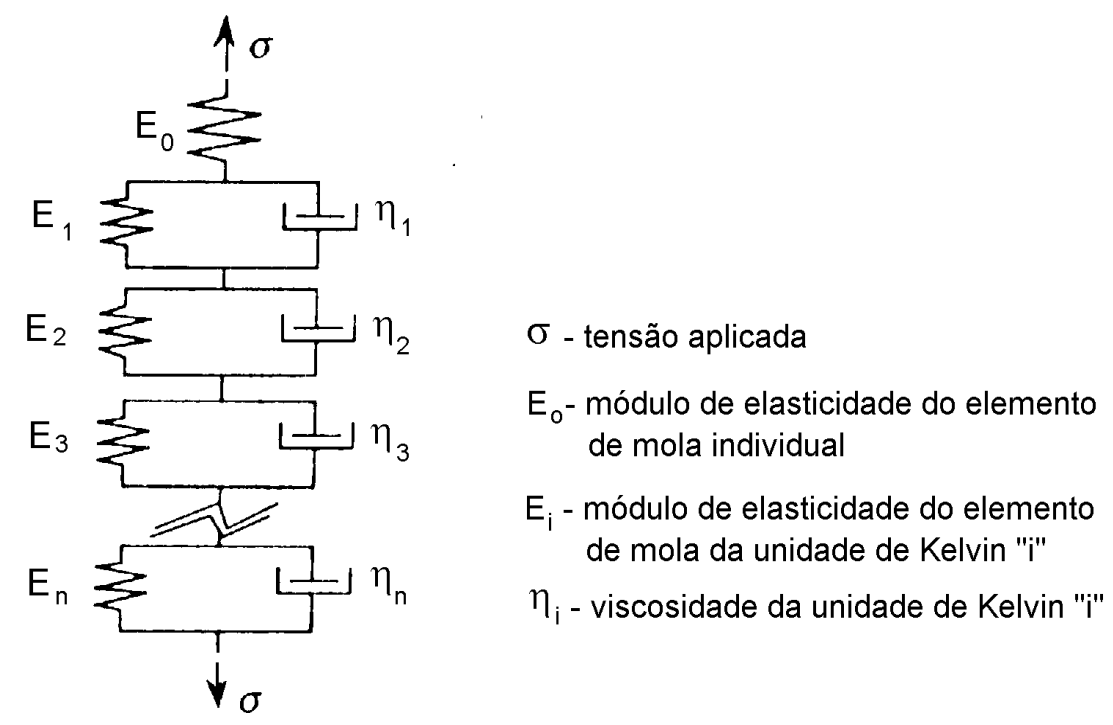

FIGURA 2.20 - Modelo reológico de Boltzmann a "n" elementos (SOONG \& KOERNER, 1998).

$$
\varepsilon(t)=\sigma\left(\varepsilon_{0}+\sum_{i=1}^{n} \frac{1}{E_{i}}\left(1-e^{\frac{E_{i} \cdot t}{\eta_{i}}}\right)\right)
$$

Outros dois modelos foram propostos por SAWICKI \& KAZIMIEROWICZFRANKOWSKA (1998), após estudarem o comportamento de fluência de geotêxteis. Estes modelos (Figura 2.21) são capazes de prever não só a deformação ao longo do tempo sob carregamento constante, como também a parcela de deformação recuperável após o descarregamento, considerando o desenvolvimento de deformações plásticas. 

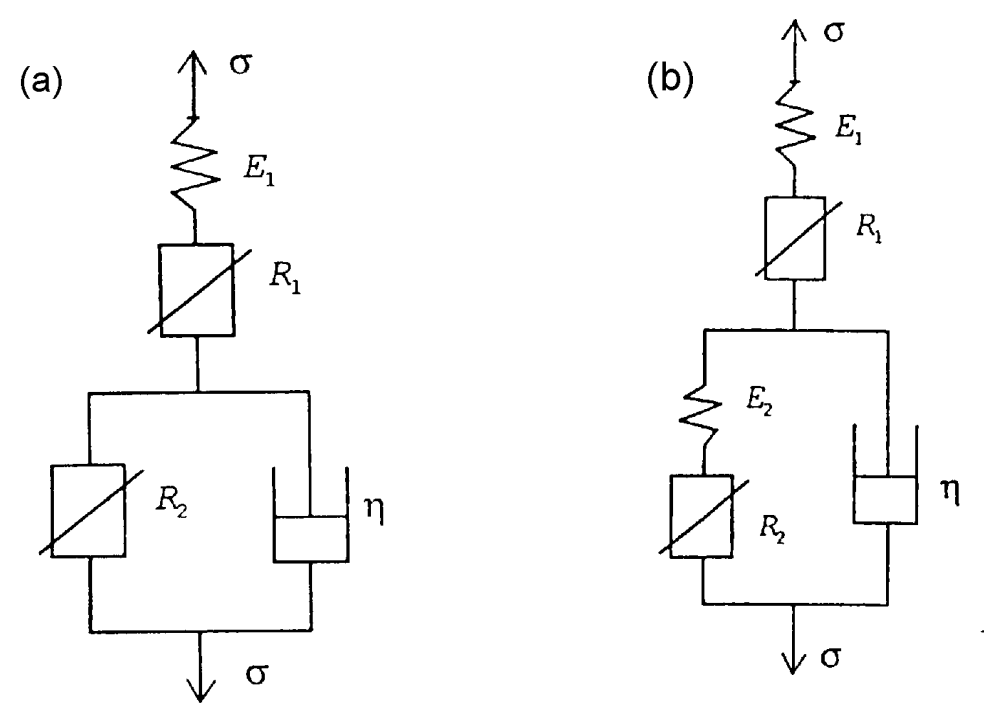

FIGURA 2.21 - (a) Modelo com quatro elementos (b) modelo com cinco elementos (SAWICKI \& KAZIMIEROWICZ-FRANKOWSKA, 1998).

O modelo composto por quatro elemento (Figura 2.21a) deve considerado em casos de níveis reduzidos de tensão, enquanto aquele constituído por cinco elementos (Figura 2.21b) se aplica a níveis elevados de tensão. As expressões (2.5) e (2.6) apresentam a solução dos modelos de quatro e cinco elementos, respectivamente.

$$
\begin{aligned}
& \varepsilon(\mathrm{t})=\sigma\left(\frac{1}{\mathrm{E}_{1}}+\frac{1}{\mathrm{R}_{1}}+\left(\frac{1}{\mathrm{R}_{2}} \cdot\left(1-\mathrm{e}^{\frac{-\mathrm{R}_{2} \cdot \mathrm{t}}{\eta}}\right)\right)\right) \\
& \varepsilon(\mathrm{t})=\sigma\left(\frac{1}{\mathrm{E}_{1}}+\frac{1}{\mathrm{R}_{1}}+\left(\left(\frac{\mathrm{E}_{2}+\mathrm{R}_{2}}{\mathrm{E}_{2} \cdot \mathrm{R}_{2}}\right) \cdot\left(1-\mathrm{e}^{\left.\left.\left.\frac{-\left(\frac{\mathrm{E}_{2} \cdot \mathrm{R}_{2}}{\mathrm{E}_{2}+\mathrm{R}_{2}}\right) \cdot \mathrm{t}}{\eta}\right)\right)\right)}\right)\right)\right. \\
& \mathrm{R}_{\mathrm{i}}=\sigma_{\mathrm{i}} / \varepsilon_{\mathrm{i}}^{\mathrm{pl}}
\end{aligned}
$$

onde,

$\varepsilon(\mathrm{t})$ - deformação total ao longo do tempo;

$\sigma$ - tensão total aplicada ao sistema;

E - módulo de elasticidade do elemento de mola; 
$\sigma_{i}-$ tensão no elemento plástico i;

$\varepsilon_{\mathrm{i}}^{\mathrm{pl}}$ - deformação do elemento plástico i;

$\eta$ - viscosidade do material.

Além das ferramentas acima descritas, a temperatura pode ser usada como aliada para acelerar ensaios de laboratório e permitir a extrapolação dos dados, considerando o tempo de vida de útil das obras, com auxílio, por exemplo, da equação de Arrhenius ou da equação Williams-Landell-Ferry (ou simplesmente equação WLF), como descrito em maiores detalhes por KOERNER et al. (1992), FARRAG (1997) e THORNTON et al. (1997).

A extrapolação de dados para materiais poliméricos, segundo JEWELL (1996), não deve exceder mais de um ciclo da escala logarítmica, assim, obras com vida útil de 100 anos requerem ensaios com 10 anos de duração. Considerando, no entanto, que os geotêxteis são materiais com utilização recente, extrapolações envolvendo dois ciclos da escala log tornam-se freqüentemente necessárias, devendo-se considerar as incertezas associadas neste procedimento, aumentando-se as margens de segurança.

\subsubsection{Equipamentos utilizados}

Os equipamentos utilizados para ensaios não-confinados são relativamente simples e apesar de algumas diferenças, envolvem três divisões básicas: sistema de ancoragem, sistema para acompanhamento das deformações e sistema de aplicação de carga, como pode ser observado na Figura 2.22. Neste equipamento, a fixação do geotêxtil é realizada através de garras que devem possuir, no mínimo, mesma largura do corpo de prova e impedir qualquer espécie de deslizamento. Um conjunto de pesos submete a amostra a um esforço de tração constante, ao passo que as deformações são obtidas ao longo do tempo, através de extensômetros.

Para os ensaios confinados, pode-se distinguir as mesmas divisões do equipamento apresentado na Figura 2.22. No entanto, a introdução de um sistema de confinamento confere algumas dificuldades com relação à montagem dos ensaios, bem como à análise dos resultados, como será visto a seguir. 


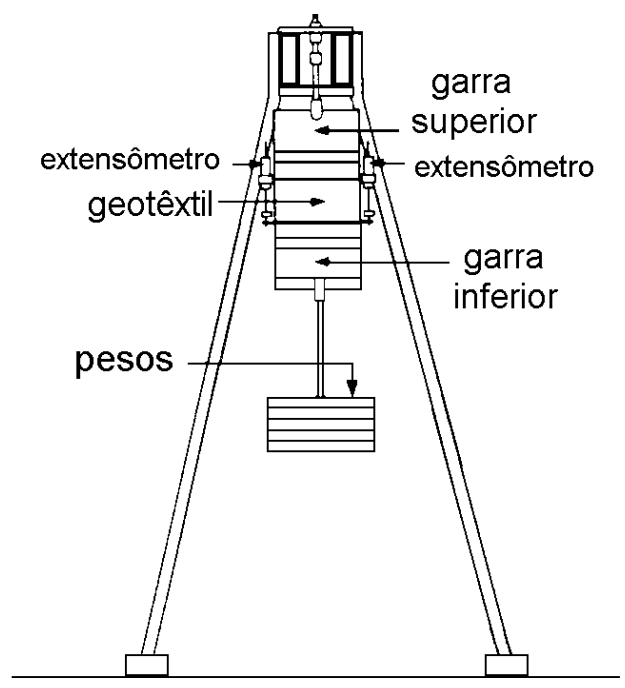

FIGURA 2.22 - Equipamento usado em ensaio de fluência não-confinada (ASTM, 1994).

Em princípio, o sistema de confinamento adotado para ensaios de fluência pode ser idêntico aos utilizados em ensaios de tração confinada. WU (1991) procede a uma ampla discussão de alguns equipamentos de tração confinada disponíveis até então, destacando alguns problemas que podem perfeitamente ser estendidos ao caso de fluência confinada. Para este autor, na maioria dos equipamentos existentes ocorre movimento relativo entre o solo confinante e o geotêxtil, provocando mobilizações de forças de atrito e/ou de adesão na interface. Esse processo resulta em um comportamento carga-alongamento que reflete dois mecanismos distintos: (i) ação do confinamento, (ii) ação de forças de atrito e de adesão ao longo da interface.

O efeito do confinamento abrange a ação da pressão na estrutura da manta e eventualmente a ação de partículas de solo impregnadas no geotêxtil. A Figura 2.23 ilustra um possível efeito das forças de atrito e adesão, mostrando um esquema de um ensaio com confinamento. Neste caso, como o solo encontra-se contido pela caixa, caso seja aplicada uma força $(\mathrm{P})$ tracionando o geotêxtil, o movimento relativo solo-geotêxtil e solo-garra, ocasionado pela deformação do geotêxtil, provocará o aparecimento de tensões cisalhantes. Este fato submete o corpo de prova a cargas diferentes ao longo de seu comprimento e inferiores àquela que foi aplicada, como mostra a Figura 2.23, para a carga (P'), atuando na seção transversal correspondente ao corte $\mathrm{AB}\left(\mathrm{P}^{\prime}<\mathrm{P}\right)$. 


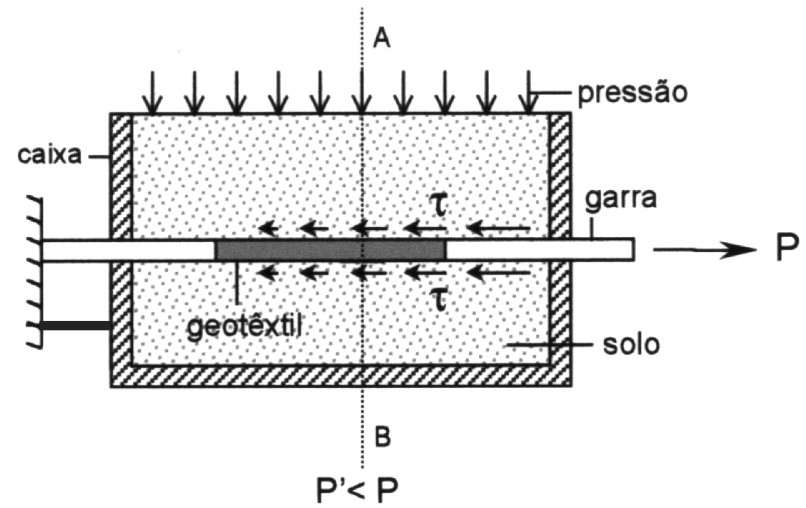

FIGURA 2.23 - Efeito de tensões cisalhantes em ensaios confinados.

Em virtude do maior número de configurações diferentes, para o caso de tração confinada, alguns equipamentos desenvolvidos para esse fim passam a ser apresentados, com o intuito de expor e discutir os principais problemas encontrados em virtude da necessidade de confinamento do geotêxtil.

\section{- Equipamentos de tração confinada}

- $\quad$ MAcGOWN et al. (1982)

O sistema de confinamento proposto por MAcGOWN et al. (1982) e que serviu de referência para muitos outros equipamentos desenvolvidos posteriormente, pode ser observado na Figura 2.24, tendo sido concebido tanto para a realização de ensaios de tração bem como, de fluência e de relaxação.

Neste dispositivo, o geotêxtil é confinado em contato com delgadas camadas de solo (10 ou $25 \mathrm{~mm}$ de espessura), em ambas as faces, sendo a tensão confinante aplicada através de bolsas pressurizadas por ar comprimido, com capacidade máxima de $250 \mathrm{kPa}$.

Cada bolsa é inserida em uma caixa metálica e nas proximidades das garras, o geotêxtil é reforçado com a aplicação de uma resina. Algumas células de carga são estrategicamente posicionadas a fim de verificar processos de transferência da carga aplicada para partes do equipamento, em virtude de forças de atrito mobilizadas nas interfaces solo-geotêxtil e solo-zonas reforçadas. 


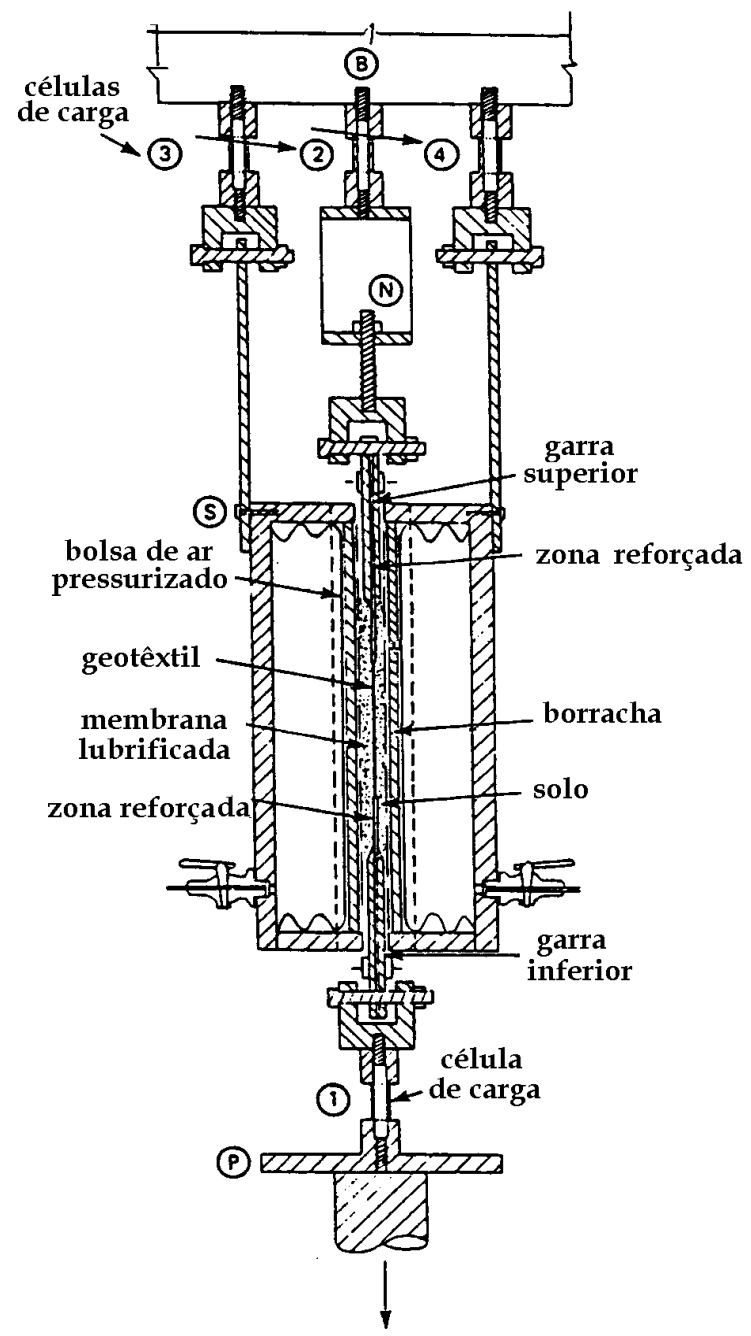

FIGURA 2.24 - Sistema de confinamento (MAcGOWN et al., 1982).

Entre as dificuldades encontradas por ocasião do desenvolvimento deste equipamento, os autores apontam a manutenção do contato solo-geotêxtil durante o processo de deformação, perfuração da bolsa por partículas de solo e transferência da carga aplicada em virtude de forças de atrito. As principais críticas associadas a esse equipamento dizem respeito às dificuldades de montagem do ensaio, principalmente com relação à preparação do solo. Nos ensaios desenvolvidos pelos autores, foram utilizadas unicamente camadas de areia, no entanto, a necessidade de compactação, caso outros tipos de materiais sejam considerados, deve constituir um empecilho para uso desse aparelho, exigindo algum tipo de adaptação. 


\section{- KOKKALIS \& PAPACHARISIS (1989)}

Estes autores propuseram um equipamento de tração confinada a partir de algumas modificações nas caixas utilizadas em ensaios de cisalhamento de grande porte $(30 \times 30 \mathrm{~cm})$. A Figura 2.25a apresenta um esquema do referido equipamento.

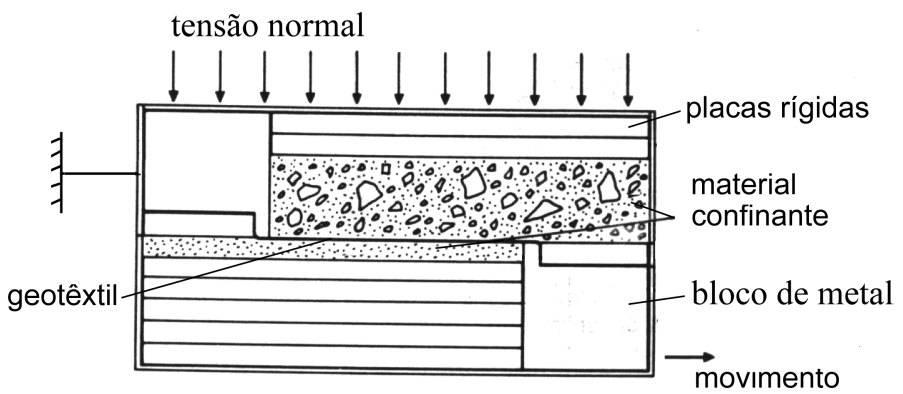

(a)

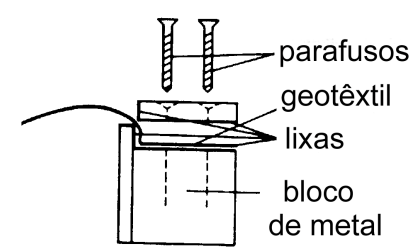

(b)

FIGURA 2.25 - Equipamento de tração (modificado de KOKKALIS \& PAPACHARISIS, 1989).

A modificação das caixas de cisalhamento envolve basicamente a adição de dois blocos metálicos (um por caixa), sendo cada bloco composto por duas partes (Figura 2.25b). A fixação do corpo de prova ocorre envolvendo-se a extremidade do geotêxtil por camadas de lixa e pressionando-se posteriormente, as duas peças que compõem cada bloco, através de parafusos (Figura 2.25b). Com a movimentação da caixa inferior enquanto a superior permanece estacionária, o geotêxtil é tracionado sob confinamento.

Um dos problemas associado a esse equipamento diz respeito a possibilidade do corpo de prova não permanecer em um mesmo plano durante o ensaio, caso a camada inferior de solo sofra deformações excessivas em virtude da aplicação da tensão confinante. Além disso, a movimentação relativa das caixas provoca mobilização de forças de atrito entre as faces dos blocos metálicos e o solo que devem ser quantificadas a fim de não introduzir erros nos resultados. Os autores também relatam que em alguns casos, houve deficiência do sistema de ancoragem, ocorrendo deslizamentos entre o geotêxtil e os blocos. 
- PALMEIRA (1990)

O equipamento desenvolvido por PALMEIRA (1990) e utilizado por GOMES (1993) e TUPA (1994) pode ser observado na Figura 2.26. É composto por uma caixa de aço bipartida, estando a parte inferior da caixa apoiada sobre rolamentos. O geotêxtil é reforçado por resina em suas extremidades, além do domínio das garras, e tracionado entre duas camadas de solo. O corpo de prova é confinado com o auxílio de uma bolsa de borracha contendo ar comprimido.

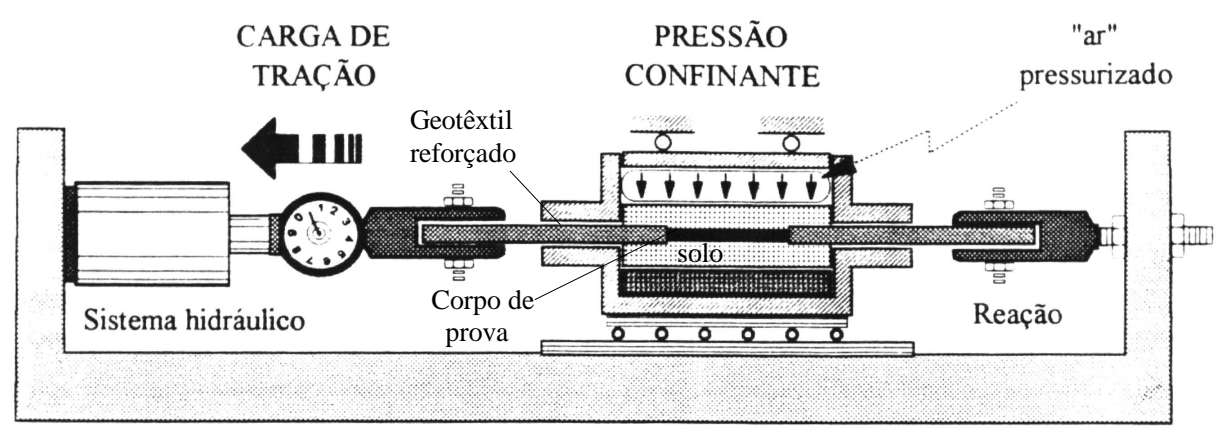

FIGURA 2.26 - Equipamento de tração confinada (TUPA, 1994).

O mesmo problema relatado anteriormente, ou seja, a possibilidade do geotêxtil não permanecer em um mesmo plano durante o ensaio pode ser estendido a esse tipo de equipamento. TUPA (1994) realizou uma simulação numérica de um ensaio de tração confinada cujos resultados sugerem que o corpo de prova poderia estar submetido, no decorrer do ensaio, a uma pressão inferior àquela aplicada pela bolsa. Tal fato ocorre em virtude do arqueamento do solo em conseqüência da elevada deformabilidade a compressão do geotêxtil e da presença das regiões enrijecidas. Ensaios utilizando este equipamento ainda incorporam alguma parcela de atrito na interface (GOMES, 1993).

- $\quad$ LING et al. (1992)

O equipamento desenvolvido por esses autores (Figura 2.27) é semelhante aos utilizados em ensaios convencionais de compressão e extensão triaxial de solos. O geotêxtil pode ser tracionado entre camadas de solo envolvidas por uma membrana 
de borracha (ensaios com solo) ou apenas inserido na membrana (ensaios com membrana), em ambos os casos a presença de confinamento é possível mediante aplicação de sucção à membrana de borracha.

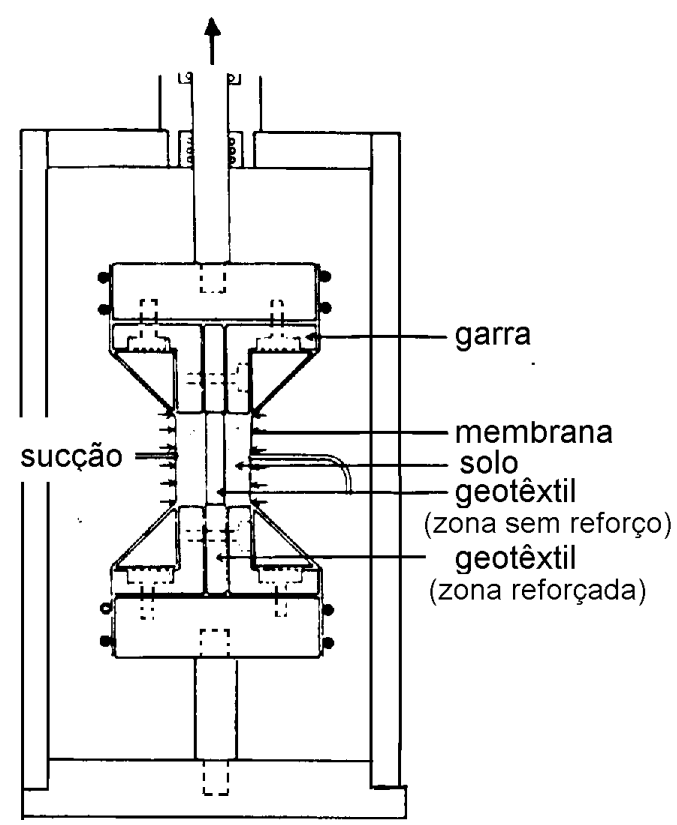

FIGURA 2.27 - Equipamento de tração confinada (LING et al., 1992).

As extremidades do geotêxtil são reforçadas por resina epoxi a fim de possibilitar a fixação às garras, projetadas para permitir a acomodação de duas camadas prismáticas de solo com $8 \mathrm{~mm}$ de espessura. A adoção de camadas delgadas visa minimizar os efeitos da resistência à tração do solo.

A medida que forças de tração são aplicadas, solo e geotêxtil deformam a uma mesma velocidade, sendo a carga efetivamente aplicada ao geotêxtil obtida considerando as perdas em decorrência da resistência à tração do solo e da membrana.

Segundo os autores, esse equipamento propicia compatibilidade de deformação entre o solo confinante e o geotêxtil. Talvez, de todos as propostas de ensaios, essa seja realmente, a que mais se aproxima dessa condição, no entanto, torna-se necessário um conhecimento prévio do comportamento do solo utilizado, em ensaios de extensão triaxial. Além desse aspecto, as dificuldades envolvidas no processo de preparação das camadas de solo constituem um grande inconveniente deste equipamento. 
Outras propostas para ensaios de tração confinada ainda podem ser encontradas (ex. EL-FERMAOUT \& NOWATZKI, 1982; LESHCHINSKY \& FIELD, 1987; SIEL et al.,1987; WU \& ARABIAN, 1990, WILSON-FAHMY et al., 1993), no entanto, tratam-se de dispositivos, de uma forma geral, semelhantes àqueles anteriormente apresentados.

Além dos problemas já abordados, WU (1991), ao analisar alguns dos equipamentos anteriormente detalhados, destaca que tanto o proposto por MAcGOWN et al. (1982) quanto por KOKKALIS \& PAPACHARISIS (1989) incorporam simultaneamente efeitos de atrito e de confinamento. A Curva típica da distribuição da tensão de cisalhamento na interface, ao longo do comprimento do corpo de prova, pode ser observada na Figura 2.28 para o caso do equipamento de MAcGOWN et al. (1982). De acordo com esta figura, percebe-se uma distribuição não uniforme das tensões de cisalhamento que decrescem em direção à extremidade fixa do corpo de prova.

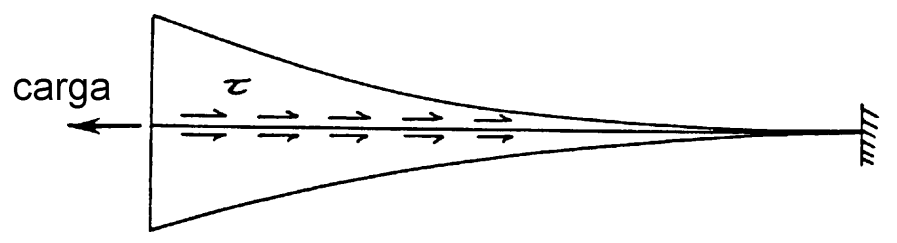

FIGURA 2.28 - Distribuição das tensões de cisalhamento no equipamento proposto por MAcGOWN et al. (1982) (WU, 1991).

Neste contexto, WU (1991) distingue duas situações de ensaio nos equipamentos de tração confinada que são denominadas "ensaio elemento" e "ensaio modelo". No primeiro caso, há uma distribuição uniforme das tensões de tração ao longo do comprimento do corpo de prova, teoricamente, o mesmo pode ser tratado como um ponto representativo de um elemento de solo reforçado de um caso real. Em oposição, nos ensaios modelos não ocorre uma distribuição uniforme das tensões de tração, o mesmo pode ser considerado, na verdade, um pequeno modelo reduzido de um sistema real, devendo-se utilizar seus resultados como parte de análises qualitativas.

A existência de atrito e ou adesão nesses tipos de equipamento constitui um grave problema relacionado a análise dos resultados, já que o comportamento carga - 
deformação obtido para um geotêxtil através de ensaio, é geralmente expresso em termos da carga aplicada. Como na verdade, o corpo de prova pode estar submetido a uma carga inferior à que foi aplicada (Figura 2.23), a utilização dos resultados de ensaio pode resultar em erros contra a segurança de uma determinada obra, uma vez que deslocamentos relativos solo-geotêxtil não devem ocorrer em estruturas de solo reforçado com geotêxteis, em condições de trabalho (LING et al., 1992).

Essa questão, no entanto, permanece ainda como o maior entrave para o desenvolvimentos de equipamentos, tanto de tração como de fluência confinada. De uma forma geral, percebe-se facilmente, que todos os equipamentos disponíveis apresentam algum tipo de limitação.

Com relação especificamente à fluência confinada, a maioria dos resultados de ensaios disponíveis na literatura (ex. LEVACHER et al., 1994; MSOUTI et al.,1997) foram obtidos utilizando-se o equipamento proposto por MAcGOWN et al. (1982), cujo sistema de confinamento foi anteriormente mostrado (Figura 2.24).

Nesse equipamento, a deformação do geotêxtil é obtida com base no deslocamento das extremidades do corpo de prova, como mostra o esquema da Figura 2.29. Para tanto, finas hastes de aço são presas nas extremidades das regiões reforçadas, perpendicularmente ao comprimento do corpo de prova, as pontas dessas hastes se encaixam nas fendas de duas placas laterais. Hastes verticais colocadas nas fendas e conectadas às hastes transversais se estendem ao exterior da caixa, sendo ligadas a relógios comparadores.

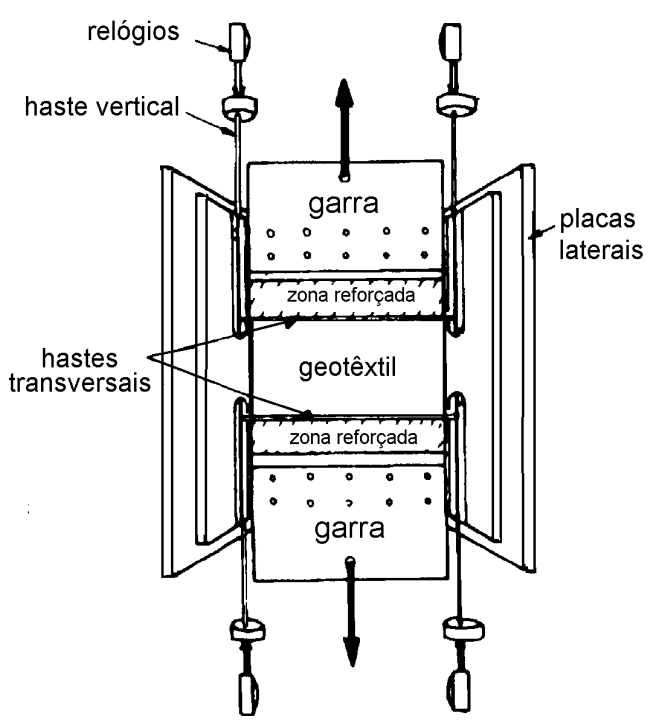

FIGURA 2.29 - Sistema utilizado para obter as deformações do geotêxtil (MAcGOWN et al., 1982). 
No caso de fluência, o sistema de aplicação de carga é composto por um conjunto de pesos. A Figura 2.30 apresenta um vista geral do equipamento em questão.

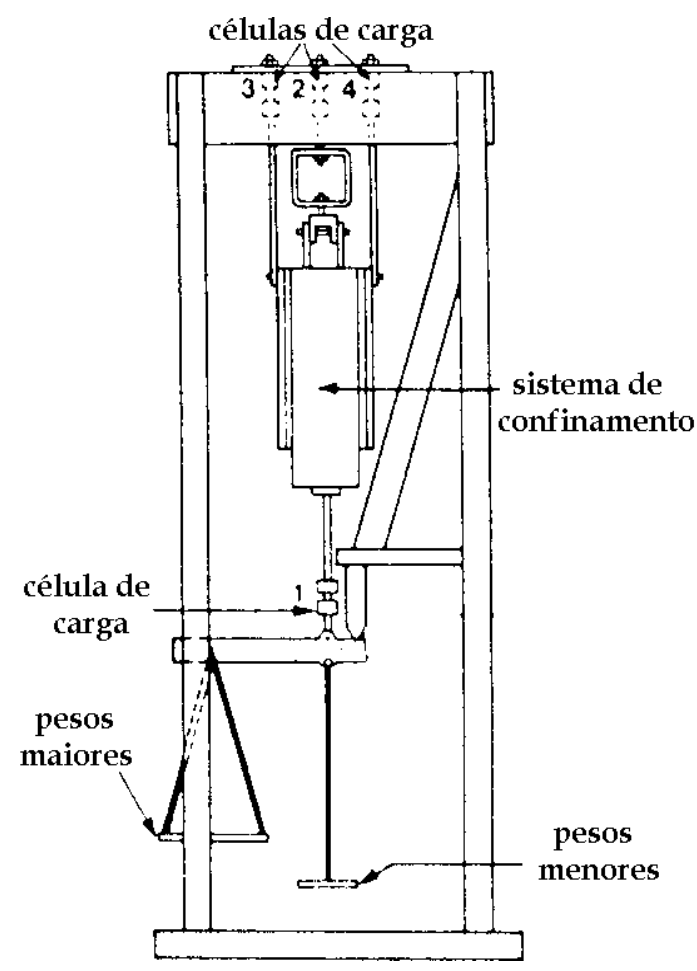

FIGURA 2.30 - Vista geral do equipamento para ensaio de fluência confinada (MAcGOWN et al., 1982)

WU \& HONG (1994) propuseram um outro tipo de equipamento para fluência confinada, baseado nos utilizados em ensaios de cisalhamento direto (Figura 2.31). Neste caso, um compressor de ar possibilita a aplicação da força de tração constante na amostra imersa entre duas camadas de solo, sendo as pressões confinantes aplicadas através de câmaras de ar. Em cada ensaio, deve-se medir o deslocamento apresentado pela garra móvel, bem como os deslocamentos de sete pontos distribuídos ao longo do comprimento do corpo de prova, no entanto, os autores não esclarecem o sistema utilizado para obtê-los.

Com base nestes dados, WU \& HONG (1994) propuseram uma metodologia para estimar o atrito desenvolvido entre o solo e o geotêxtil, a fim de excluir seu efeito na análise dos resultados. Contudo, a breve descrição do equipamento feita pelos autores, assim como a ausência de algumas informações importantes sobre a 
metodologia utilizada na análise dos resultados, impedem uma análise mais profunda dessa proposta.

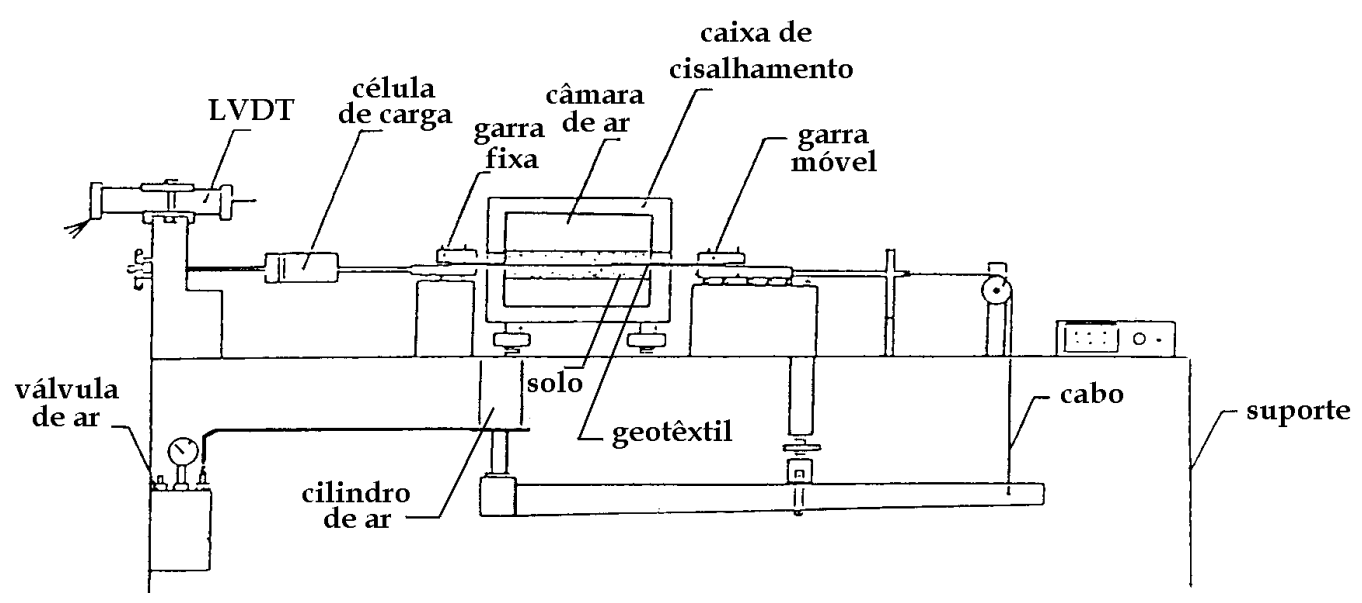

FIGURA 2.31 - Equipamento para ensaio de fluência confinada (WU \& HONG, 1994).

\subsection{3 - Fatores que afetam a fluência dos geotêxteis}

\subsubsection{Tipo de polímero e tipo de geotêxtil}

As propriedades dos polímeros influenciam de forma marcante $o$ comportamento de fluência dos geotêxteis. Sobre essa questão, a susceptibilidade à fluência aumenta na seguinte seqüência: poliéster, poliamida, polipropileno e polietileno (DEN HOEDT, 1986; ABRAMENTO, 1995).

A diferença no comportamento de fluência, em virtude do tipo de polímero, pode ser evidenciada em sua forma mais simples através das fibras que compõem os geotêxteis. A Figura 2.32. ilustra esse fato, apresentando uma comparação entre as deformações sofridas ao longo do tempo por fibras de diferentes polímeros, para dois níveis de carregamento diferentes.

No entanto, ensaios de fluência realizados com as fibras, apesar de úteis no sentido de refletir unicamente a influência do polímero, podem não reproduzir o comportamento de geotêxteis tecidos confeccionados com as mesmas fibras (GREENWOOD, 1990). Para o PET, a fluência apresentada pelas fibras é inferior à manifestada por geotêxteis tecidos, no caso do PP, fibras e geotêxteis tecidos apresentam comportamento mais semelhante (GREENWOOD \& MYLES, 1986). 


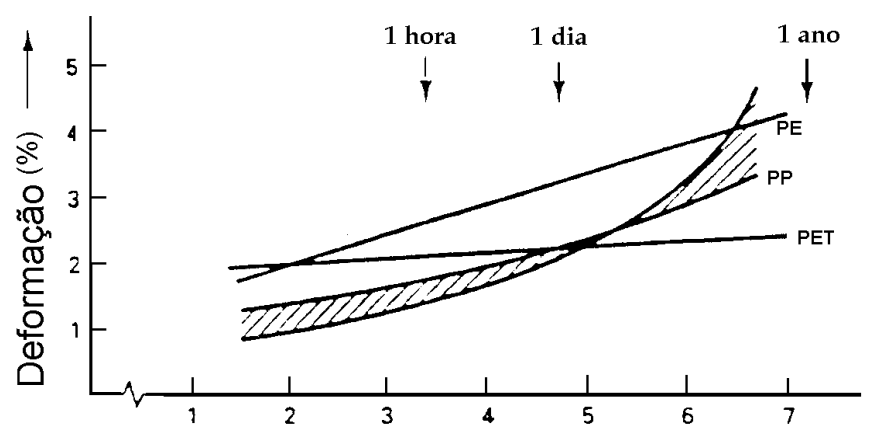

Log tempo (s)

Área hachurada corresponde aos piores e melhores resultados obtidos papa o PP.

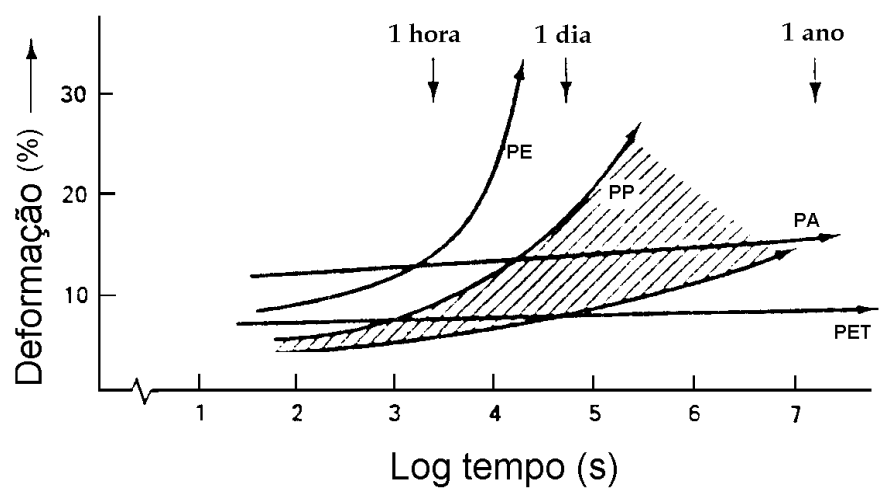

(b)

FIGURA 2.32 - Curvas de fluência para fibras de diferentes polímeros (a) 20\% da resistência à tração (b) 60\% da resistência à tração (DEN HOEDT, 1986).

Ainda não existe um consenso sobre os motivos que explicariam a maior susceptibilidade das poliolefinas (PP e PE). HORROCKS \& D'SOUZA (1992) e KOUTSOURAIS (1995) estão ente os autores que atribuem este comportamento à baixa temperatura de transição vítrea desses materiais e à conseqüente deformação das regiões amorfas. Alguns autores, entretanto, (ex. VAN ZANTEN, 1986; DEN HOEDT, 1988) consideram ainda que, embora as características de deformação a curto prazo sejam atribuídas quase que exclusivamente às regiões amorfas, a longo prazo, podem ocorrer deslizamentos entre as cadeias poliméricas nas regiões cristalinas das poliolefinas, deslizamentos estes, dificilmente possíveis para o poliéster, em virtude de sua estrutura química.

O tipo de polímero também provoca comportamentos distintos no caso de ruptura. Para os geotêxteis de poliéster a deformação de ruptura em ensaios de fluência se aproxima daquela apresentada em ensaios de tração convencionais, já no 
caso de geotêxteis de polipropileno, as deformações de ruptura por fluência são superiores às obtidas em ensaios de tração (MSOUTI et al., 1997). Esta conduta diferenciada, segundo DEN HOEDT (1986), deve-se a existência dos deslizamentos entre cadeias nas regiões cristalinas do polipropileno.

Com relação à estrutura das mantas, resultados encontrados por SHRESTHA \& BELL (1982) demonstram uma maior sensibilidade à fluência de geotêxteis não- tecidos em comparação aos tecidos. No caso dos não-tecidos, foi detectada uma fluência mais acentuada para geotêxteis com filamentos contínuos em oposição aos confeccionados com fibras cortadas. Alguns autores, como LEVACHER et al. (1994) e MSOUTI et al. (1997), no entanto, afirmam que os geotêxteis não-tecidos apresentam maiores deformações totais medidas em ensaios de fluência não-confinada, contudo, quando se considera o mesmo material não há diferença significativa no comportamento de creep entre geotêxteis tecidos e não-tecidos.

\subsubsection{Temperatura}

A temperatura acelera a fluência dos geotêxteis, razão pela qual esta variável deve ser controlada nos ensaios. Caso sejam esperadas condições severas em campo, deve-se desenvolvê-los na temperatura em que os geotêxteis irão trabalhar quando em serviço.

Os geotêxteis de polipropileno são mais sensíveis aos efeitos da temperatura que os de poliéster (MATICHARD et al., 1990; LEVACHER et al., 1994; CAZZUFFI et al., 1997) e, de acordo com ALLEN (1991), tal comportamento devese ao fato do polipropileno estar acima de sua temperatura de transição vítrea nas condições térmicas encontradas normalmente no solo, ao contrário do poliéster.

MÜLLER-ROCHHOLZ \& KIRSCHNER (1990) estudaram o efeito da temperatura, realizando ensaios de fluência em um geotêxtil tecido de PP a $10^{\circ} \mathrm{C}$ e $30^{0} \mathrm{C}$, adotando dois níveis de carregamento para cada temperatura. Os resultados encontrados por esses autores podem ser observados na Figura 2.33 e demonstram uma nítida influência da temperatura nas deformações apresentadas pelo geotêxtil. No entanto, o nível de carregamento teve uma maior influência de que a temperatura nas deformações registradas ao longo do tempo. 


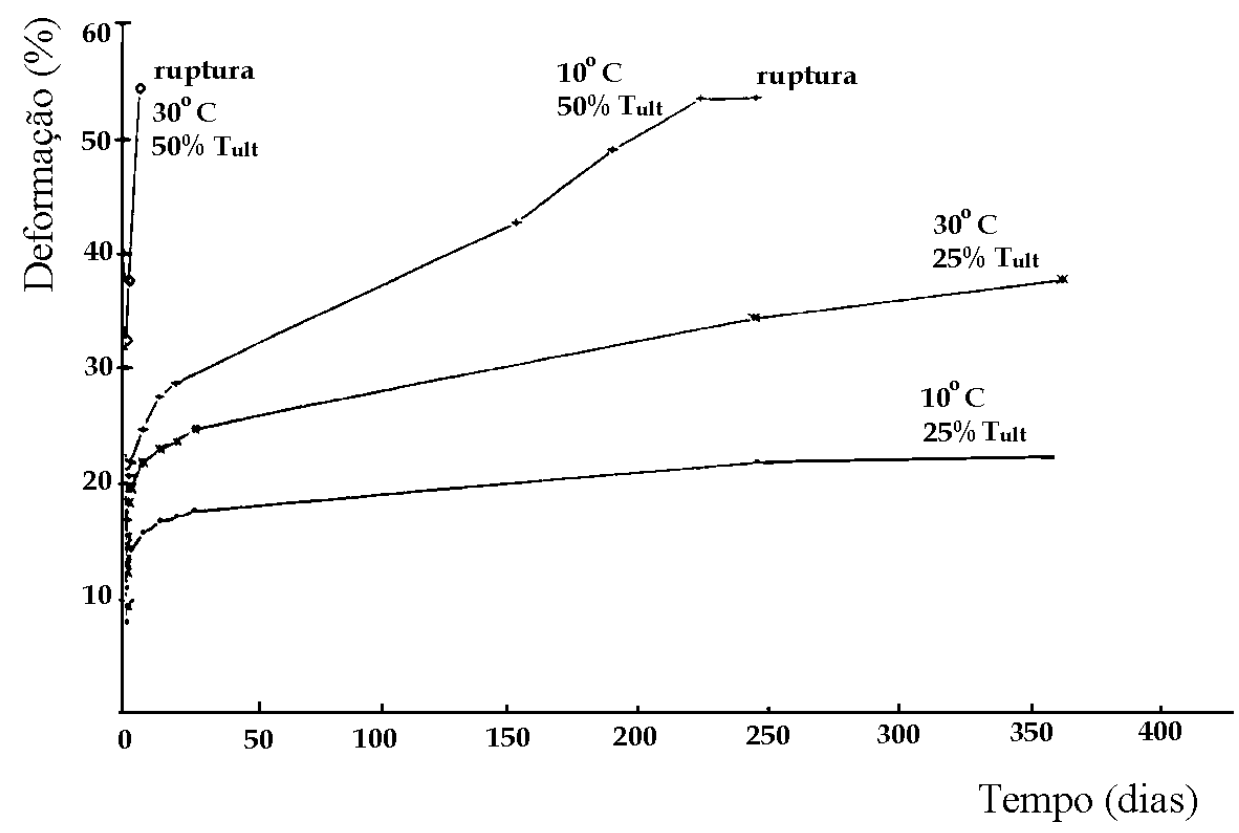

FIGURA 2.33 - Fluência de um geotêxtil de PP a diferentes temperaturas e níveis de carregamento (MÜLLER-ROCHHOLZ \& KIRSCHNER, 1990).

\subsubsection{Presença de confinamento}

O comportamento de alguns geotêxteis quando enterrados no solo, pode ser bem diferente daquele obtido em ensaios nos quais estes materiais encontravam-se em isolamento (BALLEGEER \& WU, 1993; TUPA \& PALMEIRA, 1995). Esta diferença se manifesta tanto em ensaios de tração como de fluência.

MAcGOWN et al. (1982) foram os primeiros pesquisadores a investigar o efeito do confinamento na fluência de geotêxteis. A Figura 2.34 demonstra os resultados encontrados por estes autores em ensaios com geotêxteis não-tecidos, sem e com confinamento. No caso do geotêxtil composto por $67 \%$ de polipropileno e $33 \%$ de polietileno (Figura 2.34a), o confinamento suprimiu quase que totalmente a fluência que o mesmo havia apresentado em isolamento. A notável redução das deformações totais reflete tanto uma diminuição da deformação inicial quanto das deformações dependentes do tempo e indica a possibilidade de um caráter conservativo dos resultados de ensaios de fluência não-confinada. 

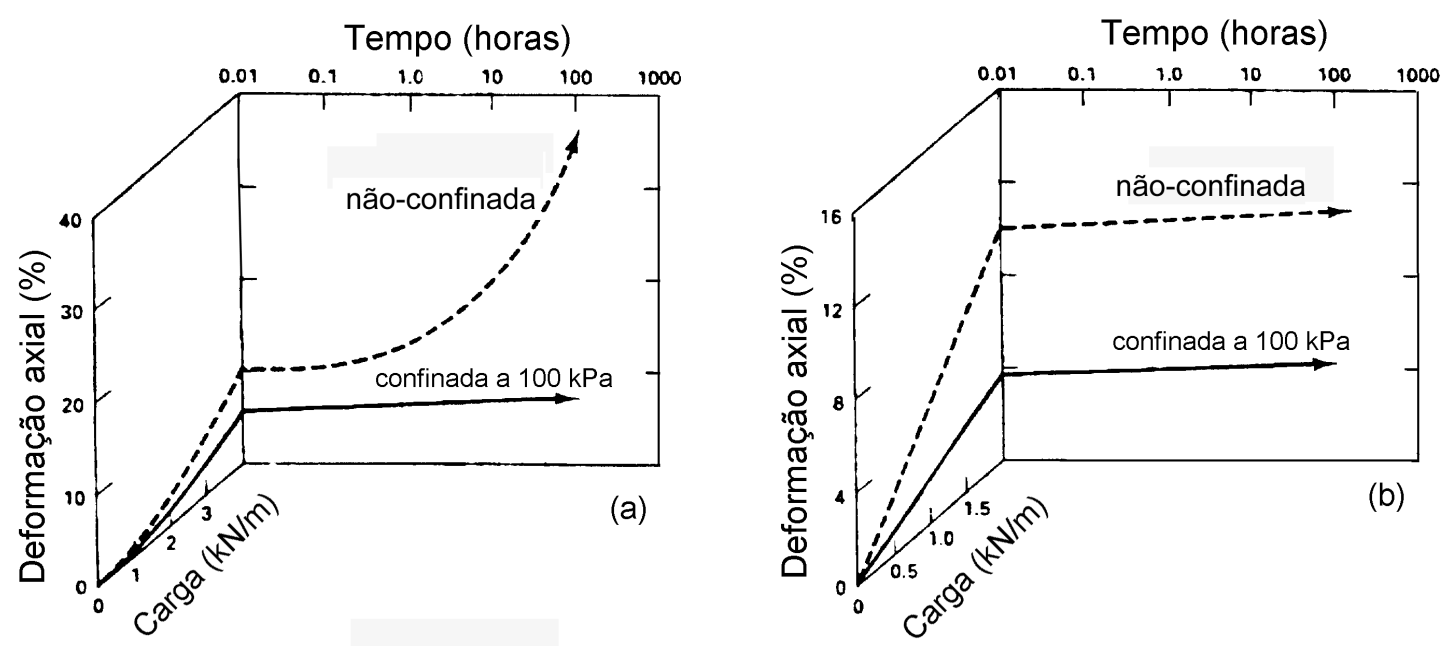

FIGURA 2.34 - Resultados de ensaios de fluência de geotêxteis (a) não-tecido, termoligado, 33\% PEAD e 67\% PP (b) não-tecido, 100\% PET, agulhado (MAcGOWN et al., 1982).

O confinamento, segundo KABIR* apud MSOUTI et al. (1997), tende a restringir o movimento das fibras, evitando o alinhamento das mesmas na direção de aplicação da carga. Por um lado, a pressão aplicada aumenta o atrito entre as fibras, por outro, a impregnação de solo na manta diminui a possibilidade de deslizamento entre fibras. A presença do solo, de acordo com JEWELL \& GREENWOOD (1988), ainda restringe a estricção da amostra.

Com relação aos geotêxteis não-tecidos, KOERNER (1994) destaca que o maior efeito ocasionado pelo confinamento está relacionado aos não-tecidos agulhados, seguidos então, pelos demais tipos (termoligados e resinados).

WU \& HONG (1994) realizaram ensaios de fluência confinada para geotêxteis não-tecidos, um termoligado, outro agulhado, compostos pela associação de PP-PE e PP-PET, respectivamente, considerando diferentes pressões de confinamento (50, 100 e $200 \mathrm{kPa})$. Os resultados obtidos confirmaram a redução da fluência por ação do confinamento, para ambos geotêxteis, no entanto, esse efeito só se apresentou significativo para uma pressão confinante de $200 \mathrm{kPa}$.

\footnotetext{
KABIR, N. (1984). In-isolation and in-soil behavior of geotextiles. 220p. Tese (Doutorado), Université de Strathclyde apud MISOUTI, M. F.; BLIVET, J. C.; LAVACHER, D. (1997). Comportement au fluage des géotextiles en reforcement mécanique. Études et recherches des laboratories des Ponts et Chaussées, GT n. 63.
} 
LEVACHER et al. (1994) também encontraram resultados menos satisfatórios que os apresentados por MAcGOWN et al. (1982), relatando a existência de apenas sensíveis diferenças entre o comportamento de fluência de geotêxteis não-tecidos isolados e confinados com $100 \mathrm{kPa}$, em uma areia fina. De qualquer forma, ainda se faz necessário uma maior quantidade de estudos antes de se tentar generalizar os efeitos do confinamento em diferentes tipos de geotêxteis.

Os geotêxteis tecidos, ao contrário de alguns resultados de materiais não- tecidos, têm demonstrado pouca ou nenhuma diferença em seu comportamento de fluência por efeito do confinamento (LEVACHER et al., 1994 ; KOERNER, 1994; MSOUTI et al., 1997).

\subsubsection{O papel da fluência no dimensionamento de muros e taludes de solos reforçados}

No dimensionamento de muros e taludes de solos reforçados com geossintéticos, duas etapas básicas podem ser identificadas: verificação da estabilidade interna e verificação da estabilidade externa. Nesta última etapa, a segurança deve ser garantida considerando-se os seguintes mecanismos de ruptura: tombamento e deslizamento na base da estrutura, capacidade de carga do solo de fundação e ruptura geral por superfícies de deslizamento envolvendo o maciço reforçado (Figuras 3.35 e 3.36), semelhantemente ao dimensionamento de estruturas de contenção convencionais.

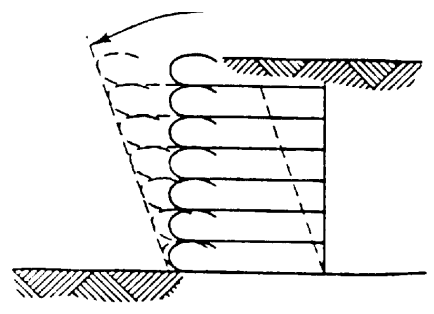

(a)

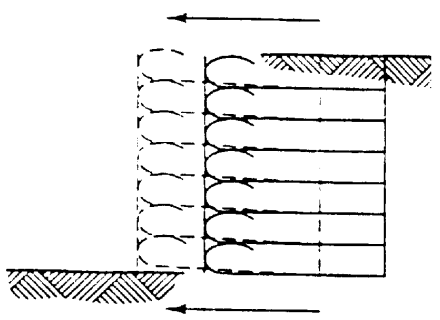

(b)

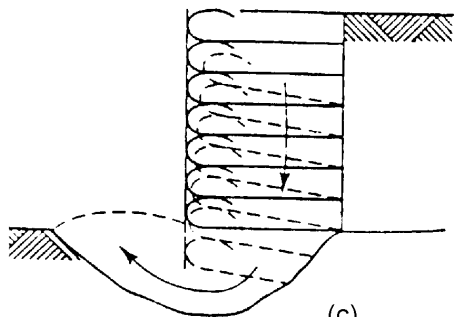

(c)

FIGURA 2.35 - Mecanismos envolvidos na estabilidade externa (a) tombamento, (b)deslizamento, (c) capacidade de carga da fundação (KOERNER, 1994) 


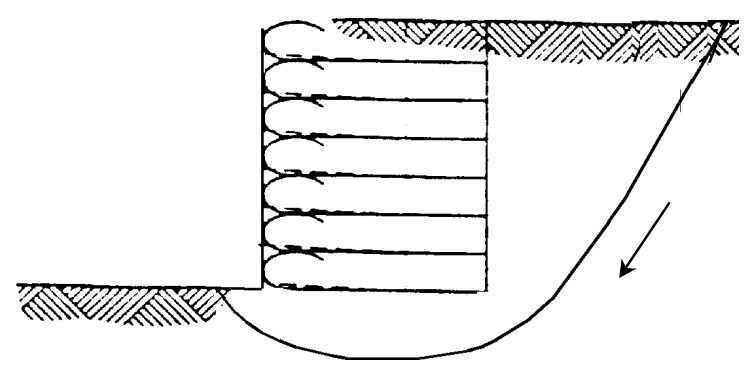

FIGURA 2.36 - Mecanismo de ruptura geral

A análise da estabilidade interna envolve dois aspectos: ruptura e arrancamento dos reforços. Nesta etapa, soluções baseadas em equilíbrio limite são empregadas, como por exemplo o método do U.S. Forest Service citado por SILVA (1996) e os propostos por LESHCHINSKY \& PERRY (1989), LESHCHINSKY \& BOEDEKER (1989) e JEWELL (1991). Estes métodos costumam dividir o maciço reforçado em duas regiões: zona ativa e resistente (Figura 2.37), devendo as inclusões resistir aos esforços de tração sem que ocorra ruptura, bem como, possuir comprimento suficiente na zona resistente a fim de evitar o arrancamento.

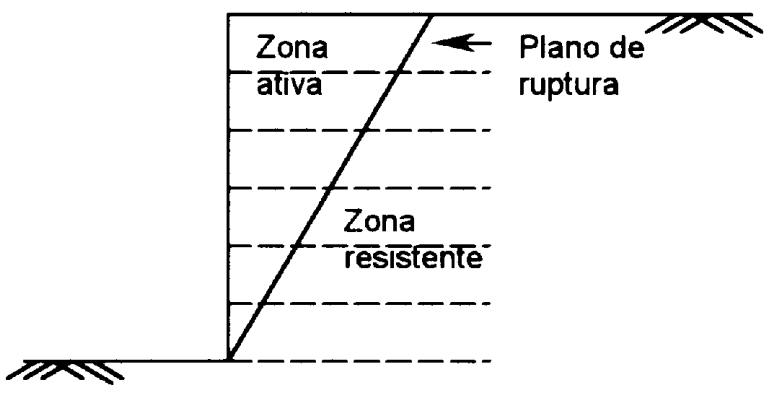

FIGURA 2.37 - Zona ativa e resistente de um maciço reforçado

Com relação à estabilidade interna, a possibilidade de ruptura é analisada comparando-se a solicitação esperada em cada inclusão com a resistência admissível à tração do reforço. Neste contexto, situam-se então as questões relativas à fluência e seus reflexos no dimensionamento de muros e taludes reforçados, já que a resistência admissível corresponde a uma parcela da resistência a curto prazo (ensaios de 
tração), em virtude da ação de diversos mecanismos que podem modificar o comportamento a longo prazo desses materiais, entre os quais a fluência.

Apesar do enfoque ao caso de muros e taludes, convém salientar que o dimensionamento das demais estruturas de solo reforçado com geotêxteis também incorpora a utilização do conceito de resistência admissível $\left(\mathrm{T}_{\mathrm{adm}}\right)$. Esse parâmetro segundo KOERNER (1994) deve ser calculado de acordo com a expressão (2.8).

$\mathrm{T}_{\mathrm{adm}}=\frac{\mathrm{T}_{\mathrm{ult}}}{\mathrm{CS}_{\mathrm{DI}} \cdot \mathrm{CS}_{\mathrm{FL}} \cdot \mathrm{CS}_{\mathrm{DQ}} \cdot \mathrm{CS}_{\mathrm{DB}}}$

Onde,

$\mathrm{T}_{\text {ult }}$ - Resistência última à tração;

$\mathrm{CS}_{\mathrm{DI}}$ - Coeficiente de segurança para danos de instalação;

$\mathrm{CS}_{\mathrm{FL}}$ - Coeficiente de segurança para fluência;

$\mathrm{CS}_{\mathrm{DQ}}$ - Coeficiente de segurança para degradação química;

$\mathrm{CS}_{\mathrm{DB}}$ - Coeficiente de segurança para degradação biológica.

Algumas variações, no entanto, podem existir com relação aos mecanismos considerados no cálculo da resistência admissível, como a utilização de coeficientes de segurança parciais distintos para degradação por radiação ultravioleta e envelhecimento químico (ex. ALLEN, 1991), ou a utilização de um único coeficiente englobando degradação química e biológica, como proposto por JEWELL \& GREENWOOD (1988).

Embora o uso de coeficientes de segurança parciais, como os apresentado na expressão (2.8), faça parte atualmente das mais modernas normas com relação à ruptura de estruturas, ALLEN (1991) destaca que sua utilização não considera, de forma racional, a existência de sinergismo entre os vários mecanismos de degradação, uma vez que nessa prática está implícito o pior caso de combinação possível. Este mesmo autor, no entanto, admite as dificuldades e a complexidade 
envolvida quando se tenta investigar o efeito de todos os mecanismo considerando suas diversas interações.

ALLEN \& BATHURST (1996) desenvolveram um trabalho pioneiro nesse sentido, ao analisar o efeito combinado da fluência e dos danos decorrentes de instalação, propondo um único coeficiente de segurança englobando ambos efeitos. Segundo estes autores a multiplicação de coeficientes de segurança distintos parece ser conservativo, sendo mais racional a utilização de um único coeficiente capaz de abranger a ação dos dois mecanismos e cujo valor é diferente do produto dos dois coeficientes de segurança parciais tradicionalmente considerados.

Independente desta questão, a prática comum continua sendo o dimensionamento utilizando expressões semelhantes à eq. (2.8). Em geral, o coeficiente de segurança com relação a fluência corresponde à relação entre a carga de ruptura convencional e a que leva o geotêxtil à ruptura em virtude desse mecanismo (ABRAMENTO, 1995). Os demais coeficientes representam a razão entre a resistência à tração de amostras intactas e de amostras submetidas ao agente de degradação em questão.

A carga de ruptura por fluência pode ser obtida através de uma série de ensaios, registrando-se o tempo necessário para que o geotêxtil sofra ruptura sob carregamento constante. Neste procedimento, costuma-se aplicar cargas entre $60 \%$ e $90 \%$ da resistência à tração o que pode resultar em tempos de observação geralmente variando de 10 horas até 1 ano (GREENWOOD, 1998). Os dados correspondentes a carga aplicada e tempo de ruptura, obtidos em diversos ensaios, são geralmente apresentados como mostra a Figura 3.38, demonstrando, na maioria das vezes, um comportamento linear (MÜLLER-ROCHHOLZ, 1998).

Com base nos resultados de ensaio, é possível realizar um estudo estatístico e traçar uma curva correspondente a um limite inferior com uma probabilidade de $95 \%$ de que qualquer outro resultado de ensaio não ultrapasse esse limite (GREENWOOD, 1998; ZAMMITT, 1998). A carga de ruptura por fluência é obtida através da extrapolação da curva de limite inferior, tendo em vista o tempo de utilização da obra, no caso da Figura 3.38, 120 anos. 


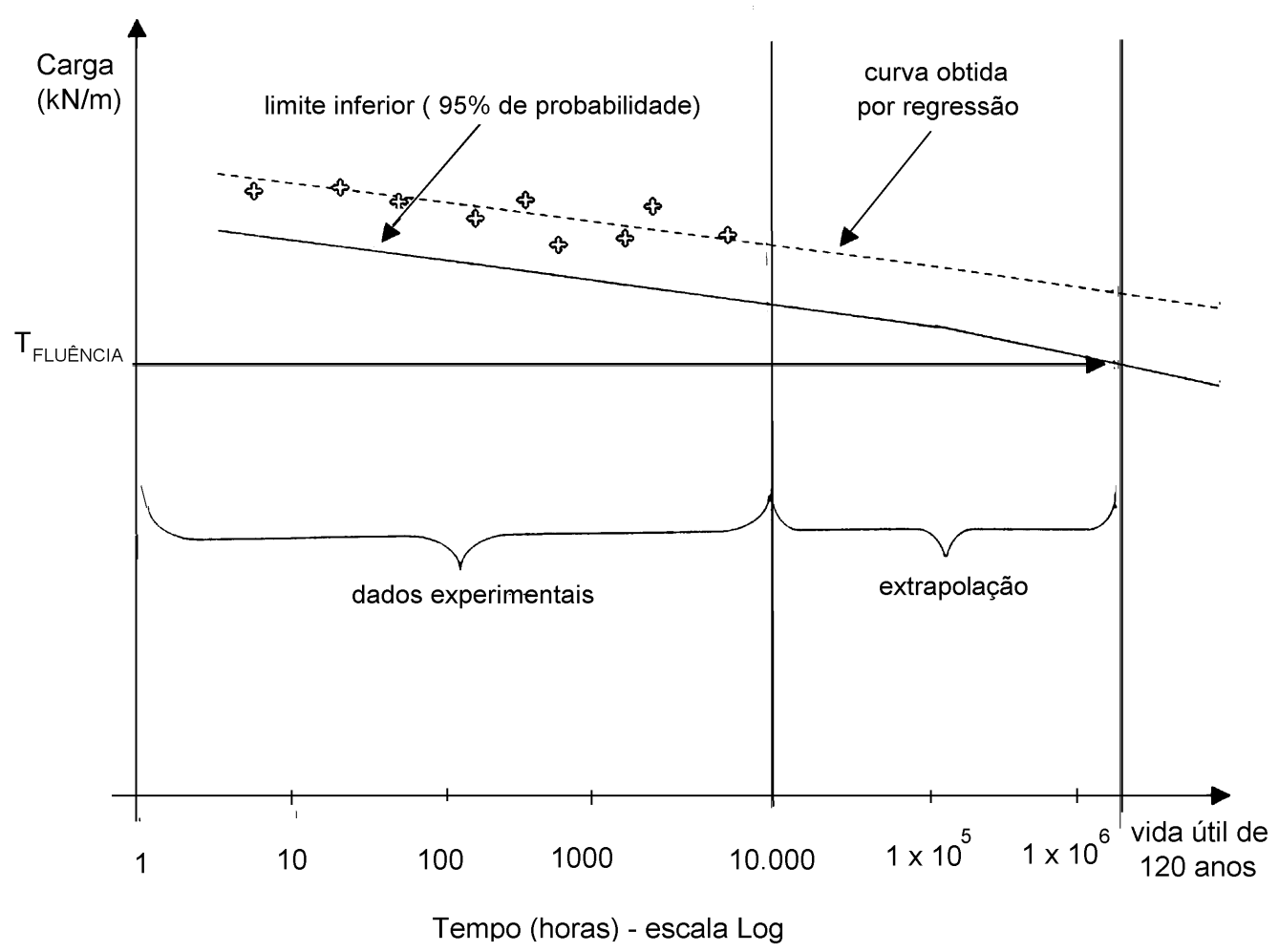

FIGURA 3.38 - Determinação da carga de ruptura por fluência (ZAMMITT, 1998)

Alguns coeficientes de segurança encontrados na literatura, para fluência de geotêxteis, considerando diferentes tipos de polímeros encontram-se na Tabela 2.2. Os valores mais baixos devem ser aplicados a obras com uma menor vida útil, enquanto os valores mais elevados se aplicam a situação inversa.

TABELA 2.2 - Coeficientes de segurança para fluência (KOERNER, 1994)

\begin{tabular}{l|c|c|c}
\hline Polímero & DEN HOEDT (1986) & LAWSON $^{(1)}$ & KOERNER (1994) \\
\hline Polipropileno & 4,0 & $2,5-5,0$ & $3,0-4,0$ \\
Polietileno & 4,0 & $2,5-5,0$ & $3,0-4,0$ \\
Poliamida & 2,5 & $1,5-2,5$ & $2,0-2,5$ \\
Poliéster & 2,0 & $1,5-2,5$ & $2,0-2,5$ \\
\hline
\end{tabular}

Os coeficientes de segurança empregados para o cálculo da resistência admissível possuem uma ampla faixa de variação a depender do tipo de obra e do tipo de polímero. A Tabela 2.3 serve de indicativo com relação a valores utilizados

(1) LAWSON, C. R. (1986). Geosynthetics in soil reinforcement. In: Symposium on geotextiles in civil engineering. Proceedings. Newcastle. p.1-13. 
em projetos de muros de solos reforçados com geotêxteis. Como pode ser observado, os maiores valores presentes na Tabela 2.3 encontram-se associados à fluência, ratificando a importância desse tema.

TABELA 2.3 - Coeficientes de segurança parciais (KOERNER, 1994)

\begin{tabular}{c|c|c|c}
\hline $\begin{array}{c}\text { Danos de } \\
\text { instalação }\end{array}$ & *Fluência & $\begin{array}{c}\text { Degradação } \\
\text { química }\end{array}$ & $\begin{array}{c}\text { Degradação } \\
\text { biológica }\end{array}$ \\
\hline 1,10 a 2,0 & 2,0 a 4,0 & 1,0 a 1,5 & 1,0 a 1,3 \\
\hline
\end{tabular}

* menor valor para aplicações com pequena vida útil e/ou obras onde as deformações por fluência não são importantes. 


\section{MATERIAIS E MÉTODOS}

\subsection{Fluêndia não-confinada}

\subsubsection{Equipamento desenvolvido}

O equipamento confeccionado para a realização dos ensaios de fluência não-confinada é apresentado na Figura 3.1. Como pode ser visto, esta aparelhagem inclui basicamente, um suporte metálico, garras para a fixação do geotêxtil e um conjunto de pesos responsável pela aplicação da carga.

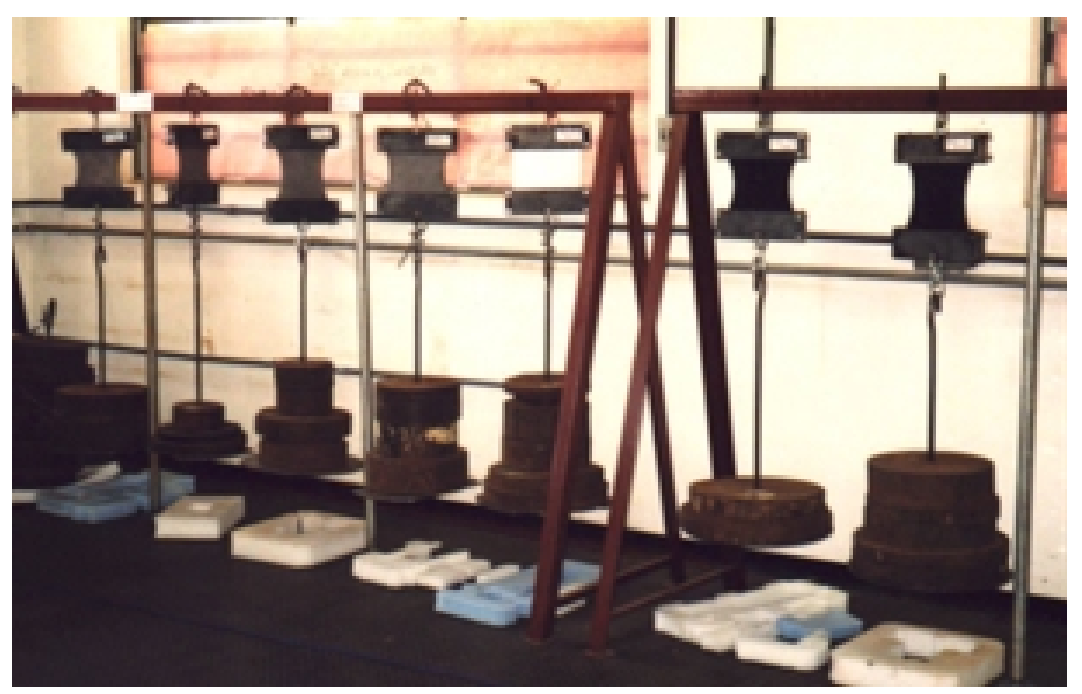

FIGURA 3.1 - Equipamento de fluência não-confinada

Como elemento de sustentação para os ensaios, utilizou-se um cavalete em aço constituído por uma viga de $6 \mathrm{~m}$ de comprimento, dividida em vãos de $2 \mathrm{~m}$. Dois suportes com 1,5 m de altura foram confeccionados a fim de atender os ensaios previstos, cada qual, com capacidade para a realização de seis ensaios simultâneos. 
No que concerne ao sistema de ancoragem adotado, as garras foram confeccionas a partir de barras de aço, sendo cada uma constituída por um conjunto de quatro peças divididas em dois tipos, duas menores (37 mm x $240 \mathrm{~mm}$ x 6,35 $\mathrm{mm}$ ) e duas maiores (77 $\mathrm{mm}$ x $240 \mathrm{~mm}$ x 7,94 mm). Esse sistema foi concebido visando a utilização de corpos de prova com $200 \mathrm{~mm}$ de largura e $100 \mathrm{~mm}$ de comprimento, podendo ser observado em maiores detalhes na Figura 3.2. A fixação ocorre enrolando-se o geotêxtil em uma das barras menores (tipo 1) que é então encostada na outra peça de mesmo tipo, sendo ambas pressionadas pelas barras maiores (tipo 2), conectando-se por fim, todo o conjunto através de parafusos. A presença de um recorte nas barras menores permite que mesmas se apoiem nos parafusos que atravessam as peças maiores.

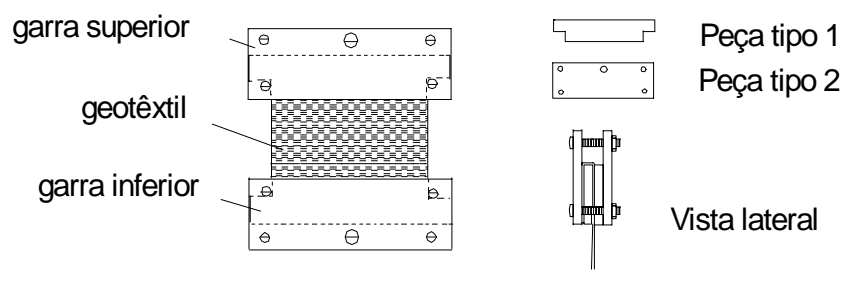

FIGURA 3.2 - Esquema das garras

Ao longo da viga do cavalete foram perfuradas áreas circulares de 12,7 mm de diâmetro a fim de permitir a passagem de um parafuso com uma corrente soldada em sua extremidade, assim o parafuso central da garra superior atravessa a corrente posicionada entre as peças tipo 2, fixando a garra no cavalete (Figura 3.3). Este mesmo preceito foi utilizado para fixar uma corrente na garra inferior na qual o conjunto de pesos é apoiado.

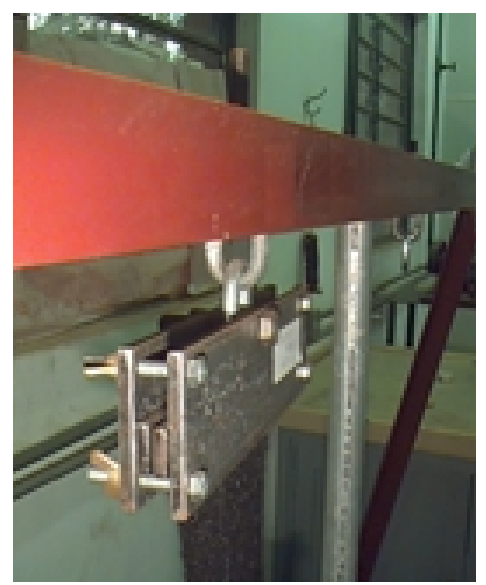

FIGURA 3.3 - Detalhe da fixação da garra no suporte 
O sistema de aplicação de carga é composto por tarugos de ferro com diferentes dimensões (diâmetro variando de 170 a $460 \mathrm{~mm}$ e altura entre 10 e 130 $\mathrm{mm}$ ) e que possuem uma abertura circular em seu centro. Esse sistema também se constitui de uma chapa metálica circular $(\mathrm{D}=300 \mathrm{~mm})$, com um orifício central que semelhantemente aos existentes nos tarugos, se destina a passagem de uma haste com 12,7 mm de diâmetro dotada de um gancho em uma de suas extremidades. A colocação da haste, após o empilhamento dos pesos sobre a chapa de apoio, possibilita a fixação do conjunto de pesos na corrente que se prende à garra inferior. A Figura 3.4 apresenta a haste e o peça de apoio mencionadas.

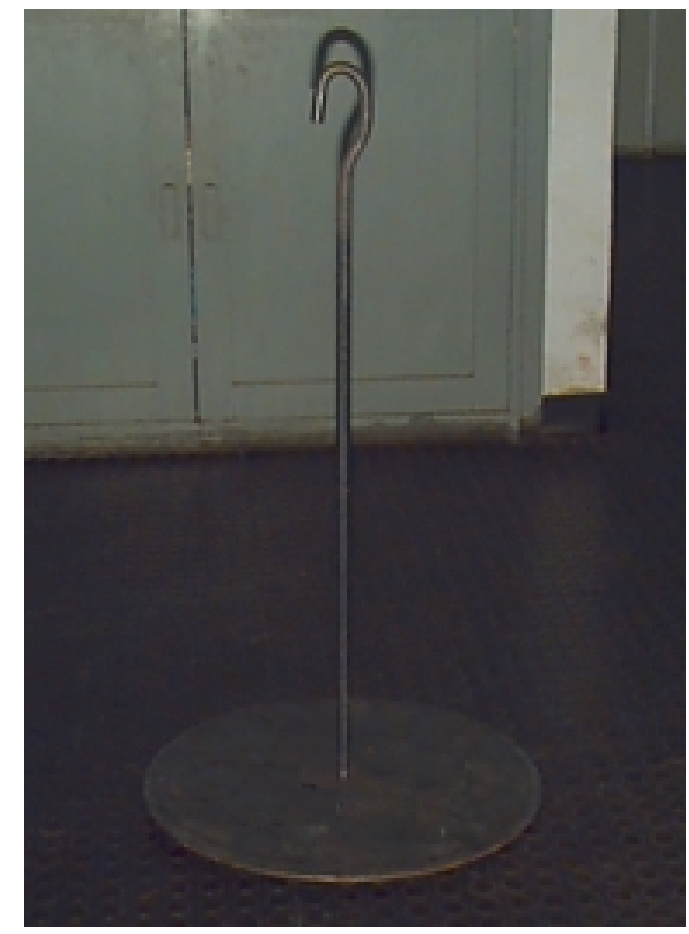

FIGURA 3.4 - Prato e haste utilizados para aplicação da carga

Convém salientar, por fim, que o equipamento em questão não dispõe de um sistema fixo para acompanhar o alongamento dos geotêxteis. Sendo o mesmo obtido através da medida do deslocamento relativo entre as garras superior e inferior (pontos 1 e 2, mostrados na Figura 3.5), utilizando um paquímetro com resolução de $0,02 \mathrm{~mm}$ da marca Mitutoyo. 


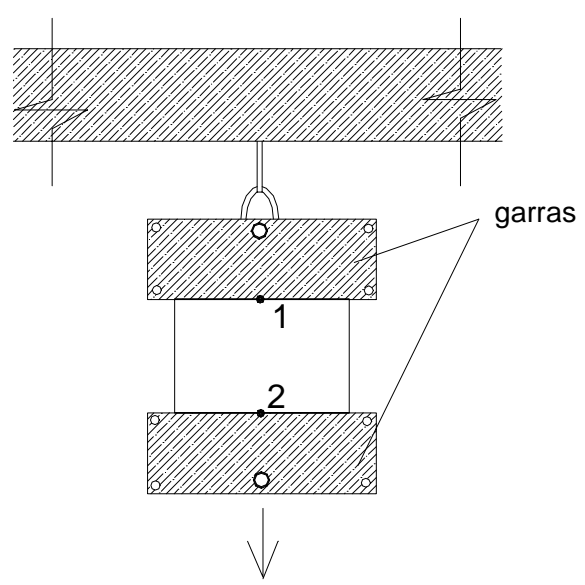

FIGURA 3.5 - Pontos utilizados para acompanhar o deslocamento entre garras.

\subsubsection{Geotêxteis utilizados}

Os ensaios foram realizados utilizando-se três geotêxteis não-tecidos agulhados, de diferentes fabricantes, todos disponíveis no mercado nacional. Algumas propriedades dos geotêxteis empregados nesta fase do trabalho podem ser observadas na Tabela 3.1, elaborada com base nos catálogos dos fabricantes.

Com relação aos geotêxteis utilizados, apenas o designado por A é fabricado a partir de filamentos contínuos de poliéster, sendo as demais mantas produzidas a partir de fibras cortadas de polipropileno.

TABELA 3.1 - Propriedades dos geotêxteis utilizados

\begin{tabular}{l|c|c|c}
\hline \multicolumn{1}{c|}{ Geotêxtil } & A & B & C \\
\hline Polímero & PET & PP & PP \\
Gramatura $\left(\mathrm{g} / \mathrm{m}^{2}\right)$ & 300 & 300 & 300 \\
Espessura nominal $(\mathrm{mm})$ & 2,6 & 2,43 & - \\
Resistência à tração "Grab" (N) & 1300 & - & 1075 \\
Alongamento na ruptura "Grab" $(\%)$ & $>70$ & - & $>70$ \\
Resistência ao puncionamento $(\mathrm{kN})$ & 3,7 & - & 0,77 \\
Resistência ao rasgo trapezoidal $(\mathrm{N})$ & 500 & - & 510 \\
Resistência ao estouro $(\mathrm{MPa})$ & 2,9 & - & 3,44 \\
Permeabilidade normal $(\mathrm{cm} / \mathrm{s})$ & $4,0 \times 10^{-1}$ & $6,7 \times 10^{-1}$ & - \\
Permissividade $\left(\mathrm{s}^{-1}\right)$ & 1,5 & 2,75 & 1,8 \\
Transmissividade $\left(\mathrm{cm}^{2} / \mathrm{s}\right)$ & $13 \times 10^{-2}$ & $2 \times 10^{-2}$ & - \\
\hline
\end{tabular}


Considerando que a carga aplicada nos ensaios de fluência constitui uma parcela da resistência à tração e portanto erros relacionados a esse valor poderiam interferir nos resultados de fluência, foram realizados ensaios de tração de faixa larga em todos os geotêxteis, de acordo com o que estabelece a ABNT (NBR 12824). A Tabela 3.2 apresenta os valores obtidos nestes ensaios (média de cinco corpos de prova), expondo ainda, os resultados encontrados na determinação da gramatura também, segundo os preceitos da ABNT (NBR 12568) e realizada a fim de evitar erros de identificação das amostras.

TABELA 3.2 - Resultados dos ensaios de tração de faixa larga

\begin{tabular}{c|c|c|c}
\hline Geotêxtil & $\begin{array}{c}\text { Resistência à tração } \\
(\mathbf{k N} / \mathbf{m})\end{array}$ & $\begin{array}{c}\text { Deformação na } \\
\text { ruptura } \\
(\boldsymbol{\%})\end{array}$ & $\begin{array}{c}\text { Gramatura } \\
\left(\mathbf{g} / \mathbf{m}^{\mathbf{2}}\right)\end{array}$ \\
\hline $\mathrm{A}$ & 19 & 54 & 288 \\
$\mathrm{~B}$ & 13,5 & 88 & 304 \\
$\mathrm{C}$ & 15 & 56,5 & 276 \\
\hline
\end{tabular}

\subsubsection{Ensaios realizados}

Os ensaios de fluência não-confinada realizados encontram-se na Tabela 3.3. $\mathrm{Na}$ ausência de uma norma brasileira, a metodologia de ensaio teve por base a norma americana ASTM D5262.

TABELA 3.3 - Ensaios de fluência não-confinada

\begin{tabular}{c|c|c|c}
\hline Designação & Geotêxtil & $\begin{array}{c}\text { Carga Aplicada } \\
\text { (\% da resistência à tração) }\end{array}$ & Duração \\
\hline NC1 & A & $60 \%$ & 8500 horas \\
\hline NC2 & B & $23 \%$ & 9000 horas \\
NC3 & & $40 \%$ & 100 horas \\
NC4 & & $46 \%$ & 9000 horas \\
NC5 & C & $60 \%$ & 9000 horas \\
\hline NC6 & & $33 \%$ & 9000 horas \\
NC7 & & $40 \%$ & 100 horas \\
NC8 & & $60 \%$ & 7500 horas \\
NC9 & & 6000 horas \\
\hline
\end{tabular}


Inicialmente, pretendia-se que os ensaios de longa duração (superior a 100 horas) fossem realizados submetendo-se os geotêxteis B e C a 20, 40 e 60\% de suas resistências à tração. No entanto, por uma questão de cronograma e de disponibilidade do equipamento utilizado para tração, os ensaios de fluência tiveram que ser montados antes dos de tração, com base nos valores fornecidos no catálogo dos fabricantes. Quando estes últimos foram realizados, os resultados encontrados diferiram daqueles presentes no catálogo, assim, a correção da carga aplicada nos ensaios de fluência, considerando a resistência obtida nos ensaios de tração, geraram os valores presentes na Tabela 3.3.

Os ensaios com 100 horas de duração foram realizados com intuito de se proceder a algumas comparações com os ensaios confinados realizados sob as mesmas condições e também, entre geotêxteis. Nestes ensaios, em virtude do tempo de duração reduzido, foi possível ensaiar três corpos de prova para cada condição de carregamento.

\subsubsection{Preparação dos corpos de prova}

Para a realização dos ensaios, primeiramente, procedeu-se a amostragem dos geotêxteis de acordo com a ABNT (NBR 12593), retirando-se amostras com $200 \mathrm{~mm}$ de largura e $360 \mathrm{~mm}$ de comprimento que após a fixação nas garras permite que apenas $100 \mathrm{~mm}$ do comprimento original sofra deformação. Os corpos de prova foram preparados de modo que a direção de aplicação da carga coincidisse com a direção de fabricação da bobina.

\subsubsection{Montagem e execução dos ensaios}

Com o geotêxtil preso às garras e já fixado ao suporte metálico, o conjunto de pesos era levantado com o auxílio de um equipamento hidráulico denominado girafa (Figura 3.6), ou através de um macaco hidráulico tipo jacaré, ambos com capacidade de $20 \mathrm{kN}$. O conjunto de tarugos era então conectado à garra inferior, sendo a carga total aplicada suavemente, no máximo, em 30 s. 


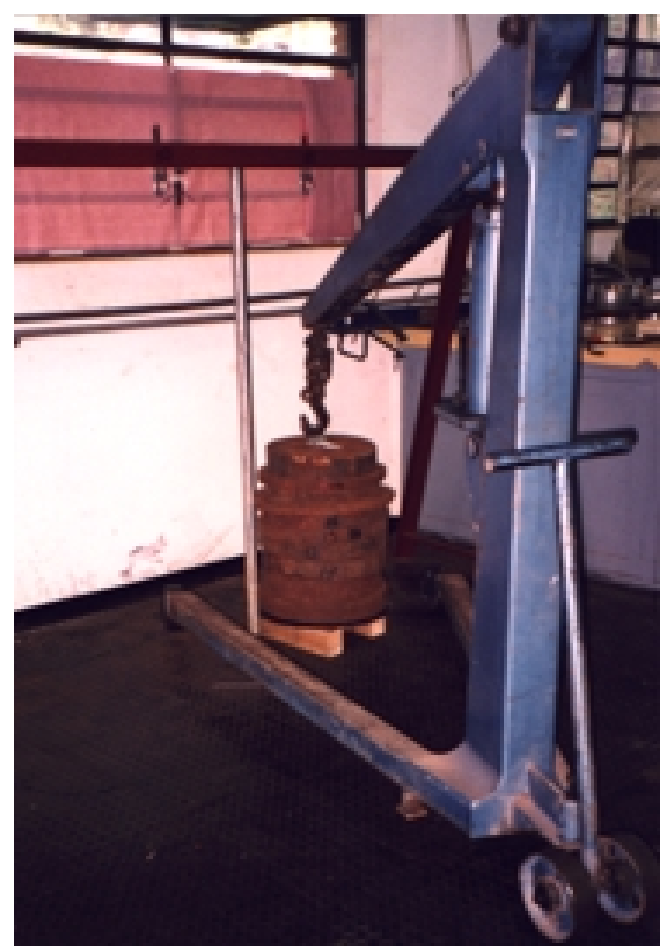

FIGURA 3.6 - Equipamento usado para erguer os pesos

Após a aplicação integral da carga, o cronômetro era acionado, dando-se início às medidas de alongamento do corpo de prova através do paquímetro. As leituras transcorreram nos tempos correspondente a 1, 2, 6, 10, 30 minutos e 1, 2, 5, 10, 30, 100, 200, 500 horas. Decorridas as primeiras 500 horas do início do ensaio, as leituras passaram a ser efetuadas em intervalos de 500 horas.

$\mathrm{Na}$ fase de montagem dos ensaios, dois geotêxteis (A e B) ambos com um carregamento correspondentes a $60 \%$ de suas resistências à tração apresentaram rupturas na região da garra (menos de 15 minutos após o carregamento). Para solucionar o problema, as regiões dos geotêxteis que seriam fixadas às garras foram reforçadas impregnando-se as mesmas com uma resina epóxi de alta resistência constituída por araldite $\mathrm{M}+$ endurecedor HY956 da Ciba-Geigy na proporção 5:1, aplicada com auxílio de um pincel. Neste caso, o corpo de prova era fixado à garra logo após a impregnação da resina.

A Figura 3.7 apresenta um esquema de um geotêxtil reforçado com a referida resina. Nestes ensaios, acompanhou-se não só o deslocamento relativo entre garras, bem como o deslocamento relativo entre os pontos 1 e 2 , localizados nas extremidades do geotêxtil livre da resina. A excelente concordância entre os dois 
tipos de medidas comprovou a inexistência de deslizamentos na garra bem como o bom desempenho da resina.

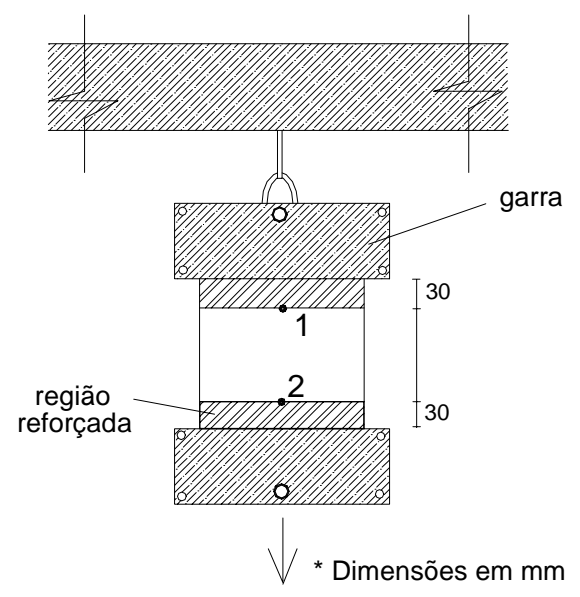

FIGURA 3.7 - Esquema de um geotêxtil reforçado.

Apesar dos ensaios não terem sido realizados em ambiente com temperatura e umidade relativa controladas, essas variáveis foram acompanhadas e revelaram valores compreendidos no intervalo estabelecido pela ASTM D5262, ou seja, em torno de $21^{0} \mathrm{C}$.

\subsection{Fluência confinada}

\subsubsection{Equipamento desenvolvido}

\subsubsection{Descrição geral}

O equipamento construído para a realização dos ensaios de fluência confinada pode ser visto na Figura 3.8. Consiste em uma caixa metálica (aço 1020) apoiada sobre uma mesa, também de aço, na qual o geotêxtil pode ser tracionado entre duas camadas de solo sob a ação de pressões confinantes aplicadas através de uma bolsa pressurizada por ar comprimido.

A aplicação da carga acontece através de um conjunto de pesos semelhante aos empregados nos ensaios sem confinamento, sendo um par de garra responsável pela fixação do geotêxtil. Neste caso, o alongamento do corpo de prova é registrado através de relógios comparadores. 


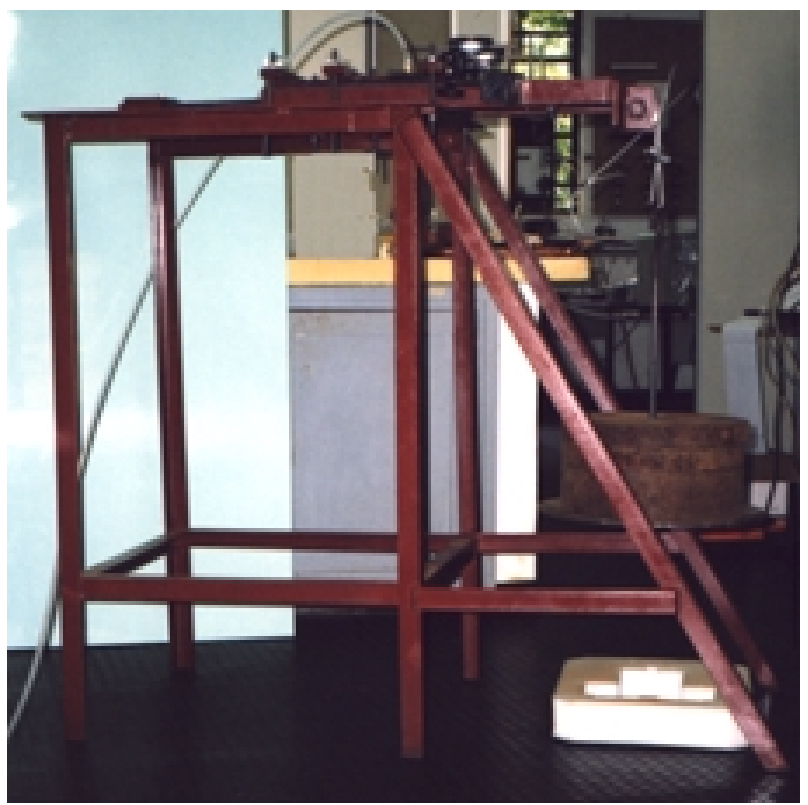

FIGURA 3.8 - Equipamento de fluência confinada.

A caixa possui largura de $220 \mathrm{~mm}, 300 \mathrm{~mm}$ de comprimento e uma altura de $42 \mathrm{~mm}$ (dimensões internas), apresentando um rasgo de $5 \mathrm{~mm}$ de altura e $205 \mathrm{~mm}$ de comprimento em duas de suas paredes laterais, ao longo da largura da peça. Tal rasgo proporciona que parte do geotêxtil tenha acesso ao exterior da caixa, possibilitando sua fixação às garras que se encontram externamente à caixa. A presença de peças móveis (Figura 3.9) em cima de cada rasgo (constituindo parte da parede lateral da caixa) facilita a colocação do geotêxtil.

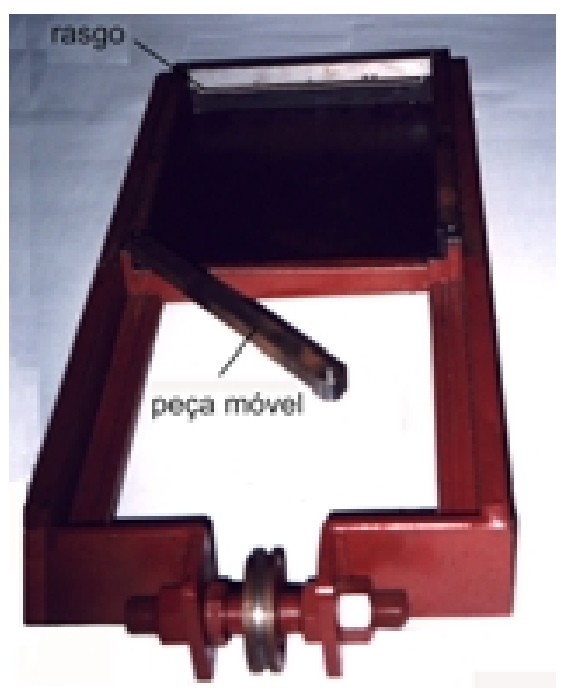

FIGURA 3.9 - Caixa de ensaios. 
Para garantir a fixação da caixa na mesa, a tampa é dotada de três traves transversais perfuradas em ambas extremidades para a passagem de parafusos que se prendem à mesa (Figura 3.10), essas traves ainda servem de reforço a fim de evitar deformações da tampa quando da aplicação de pressões elevadas.

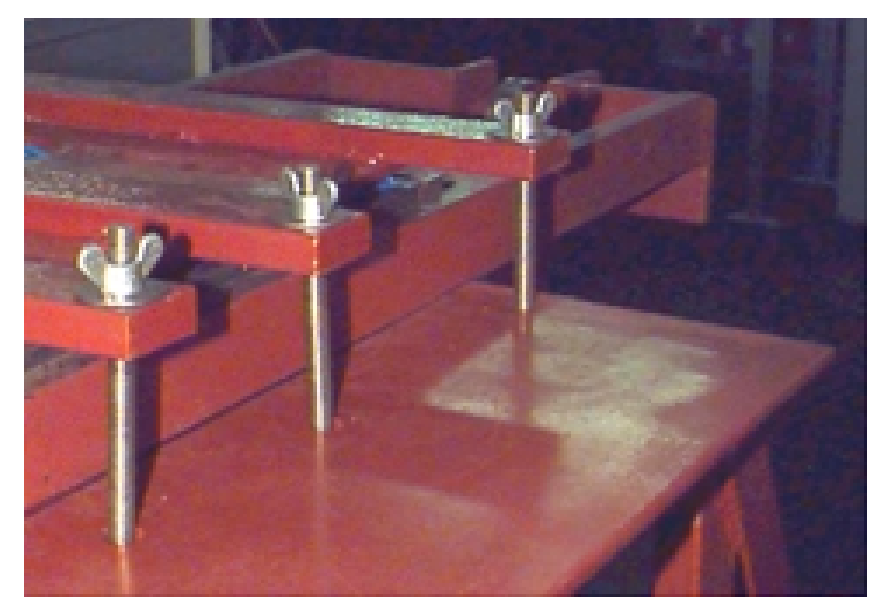

FIGURA 3.10 - Detalhe da fixação da caixa.

O sistema de ancoragem é bastante simples, tendo sido também confeccionado, visando a adoção de corpos de prova de $200 \mathrm{~mm}$ de largura. Cada garra é constituída apenas, por 2 chapas perfuradas de aço que prensam o geotêxtil através de parafusos, em regiões do mesmo que se encontram reforçadas através da impregnação de resina epoxi.

Uma das garras encontra-se fixa à mesa de apoio, sendo a outra apoiada em um braço preso à caixa de ensaios. Este braço (Figura 3.9) possui trilhos nos quais se encaixam rolamentos de esteira a fim de possibilitar o deslocamento da garra com o menor atrito possível. Na extremidade do braço, uma roldana permite a movimentação de um cabo de aço preso à garra móvel, sendo o conjunto de pesos pendurado na outra extremidade desse cabo.

A Figura 3.11 apresenta um esquema mostrando algumas partes do referido equipamento. Maiores informações sobre as dimensões desse equipamento podem ser encontradas no apêndice. 


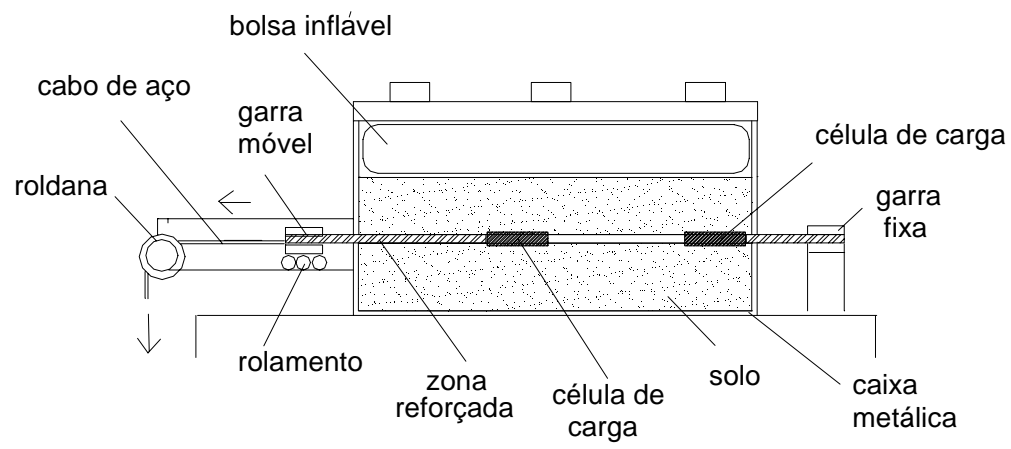

FIGURA 3.11 - Corte esquemático do equipamento de fluência confinada.

\subsubsection{A bolsa inflável}

A bolsa inflável (Figura 3.12) utilizada para a aplicação de pressões confinantes é constituída por PVC e reage contra a tampa e contra o sistema sologeotêxtil quando sob pressão. A empresa SANSUY S.A foi responsável pelo projeto e pela execução dessa peça, que possui mesmas dimensões internas da caixa e uma altura de $50 \mathrm{~mm}$, sendo capaz de trabalhar com um pressão máxima de $150 \mathrm{kPa}$.

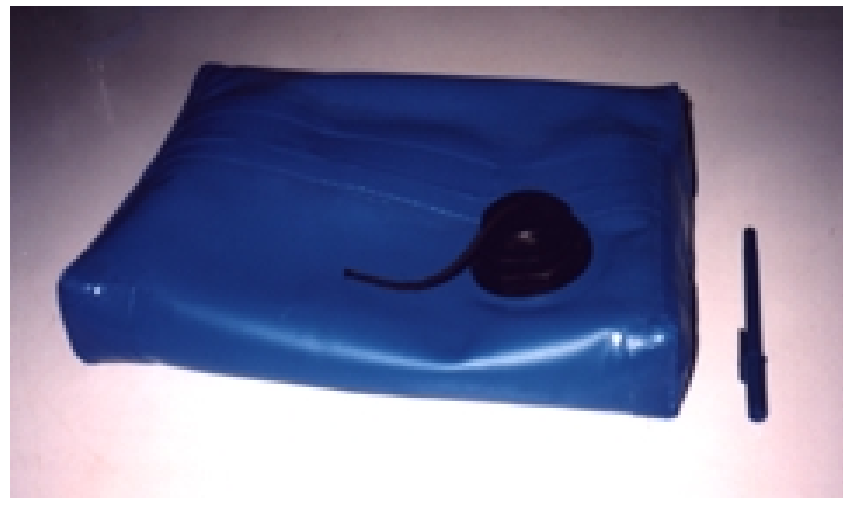

FIGURA 3.12 - Bolsa Inflável.

\subsubsection{Sistemas para obtenção das deformações do corpo de prova}

Com relação às medidas de alongamento do geotêxtil, primeiramente, optouse por um dispositivo capaz de efetuar tais medidas internamente. Para tanto, 2 hastes de latão com $2.5 \mathrm{~mm}$ de diâmetro e comprimentos de 330 e $100 \mathrm{~mm}$ eram presas em regiões do geotêxtil reforçadas pela aplicação da resina epoxi, respectivamente, nos pontos 1 e 2 mostrados na Figura 3.13, de modo que a diferença entre os 
deslocamentos apresentados pelas hastes representasse o alongamento do corpo de prova dentro da caixa. A haste menor foi colocada com o intuito de detectar algum possível deslizamento na garra fixa, bem como para verificar a existência de deformações da região reforçada.

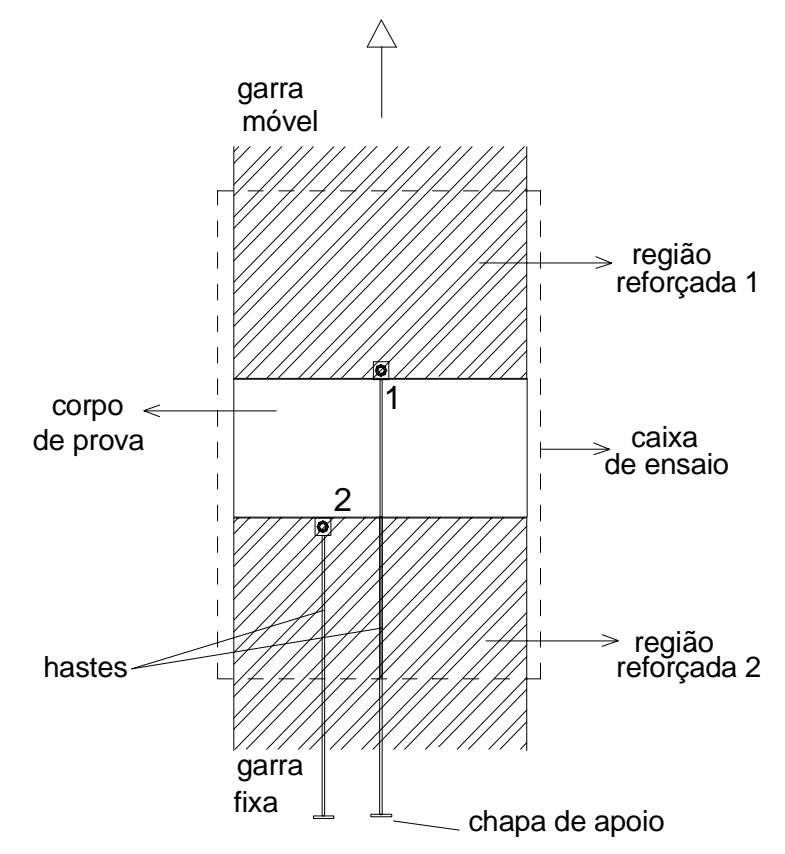

FIGURA 3.13 - Esquema dos pontos de fixação das hastes

Para permitir a fixação das hastes no geotêxtil, as mesmas possuem, em uma de suas extremidades, uma chapa retangular de $1 \mathrm{~mm}$ de espessura (10 $\mathrm{mm}$ x $15 \mathrm{~mm})$ com uma área circular perfurada de $3 \mathrm{~mm}$ de diâmetro (Figura 3.14), sendo assim, as hastes podem ser presas ao geotêxtil através de um parafuso, nas regiões reforçadas. Externamente às caixas, relógios comparadores eram acoplados às hastes, encostando-se as peças de conexão mostradas na Figura 3.15 (já presas aos relógios através de um sistema de rosca) nas chapas de apoio soldadas nas hastes (Figura 3.14).

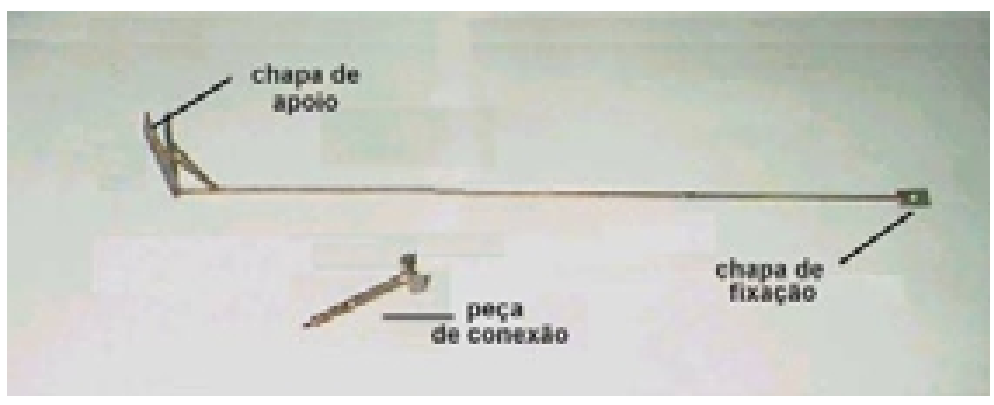

FIGURA 3.14 - Hastes para medidas internas de deslocamento 


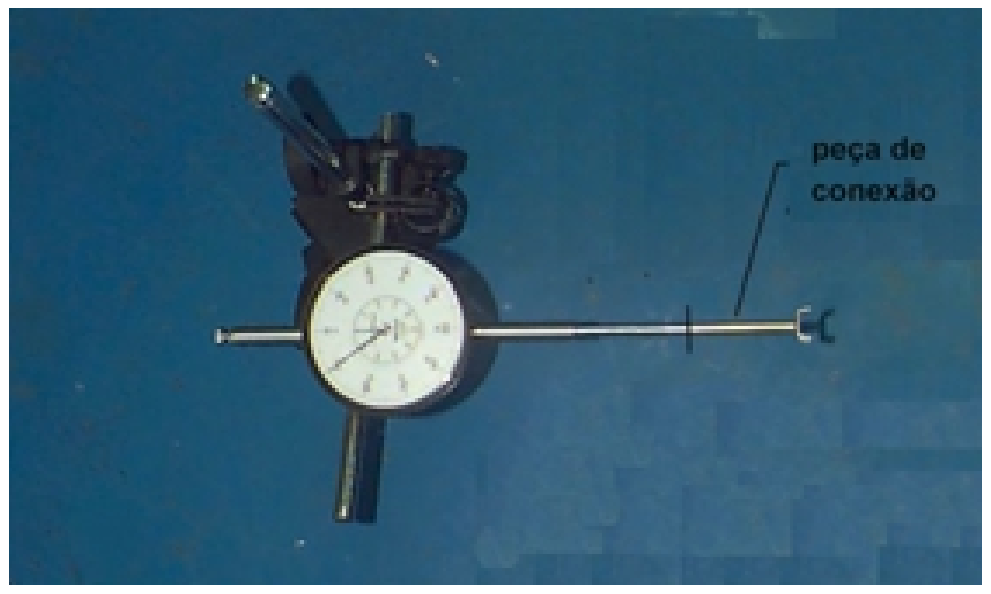

FIGURA 3.15 - Peça de conexão presa ao relógio

Dois tipos diferentes de relógios, ambos da marca Mitutoyo, foram utilizados nesta proposição, um com curso de $50 \mathrm{~mm}$ e resolução de $0,01 \mathrm{~mm}$ e outro com curso de $12,7 \mathrm{~mm}$ e resolução de 0,001 mm, para acompanhar respectivamente, a haste com menor (ponto 2) e a com maior (ponto 1) deslocamento esperado. A Figura 3.16 mostra os relógios já acoplados às hastes.

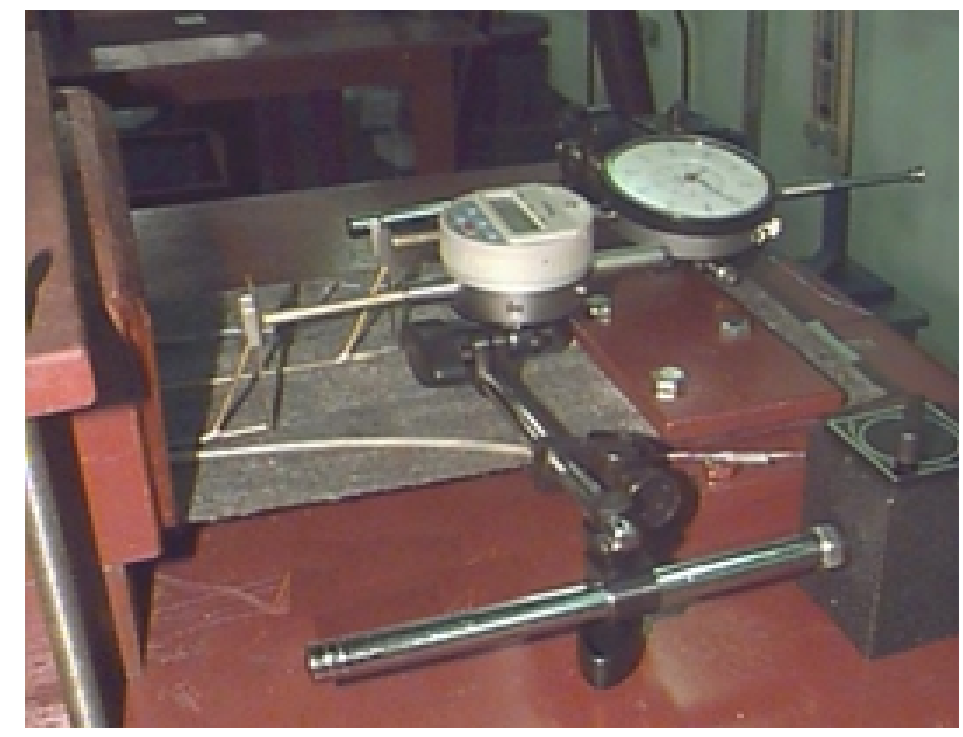

FIGURA 3.16 - Relógios acoplados às hastes

Os primeiros testes do equipamento foram então realizados através do sistema de medidas internas anteriormente descrito, contudo, em virtude da boa 
concordância entre os resultados obtidos considerando-se esse sistema e acoplandose dois relógios comparadores diretamente à garra móvel (Figura 3.17), optou-se por realizar os ensaios de fluência confinada utilizando-se esse último sistema (medidas externas). Neste caso, ambos os relógios utilizados possuíam curso de $50 \mathrm{~mm}$ e resolução de $0,01 \mathrm{~mm}$. As deformações do corpo de prova foram obtidas considerando a média das leituras dos dois relógios.

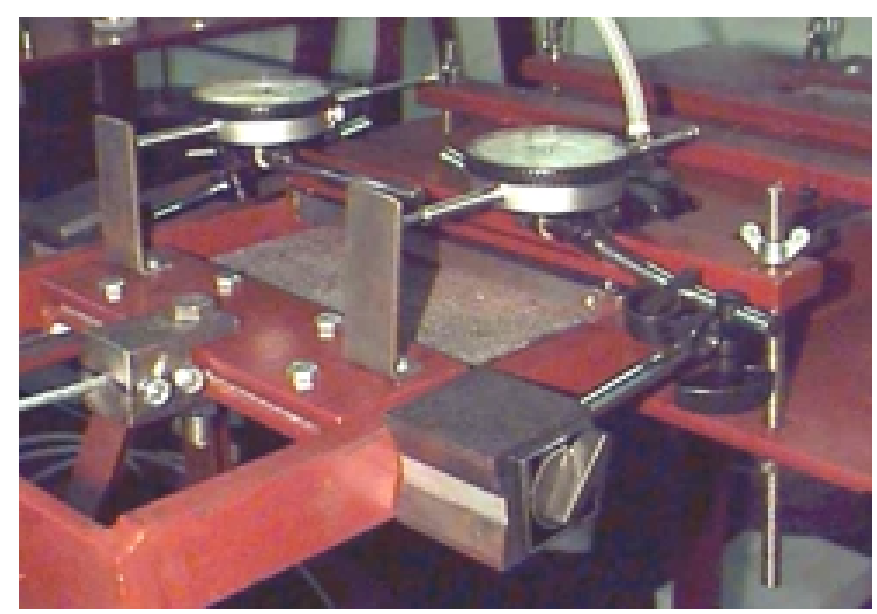

FIGURA 3.17 - Sistema para medidas externas de deslocamento

\subsubsection{Células de carga}

Para averiguar a manutenção da carga aplicada ao longo do comprimento do corpo de prova, células de carga a base de extensômetros elétricos foram confeccionadas e calibradas em laboratório, podendo ser fixadas diretamente nas regiões reforçadas dos geotêxteis através de parafusos (Figura 3.18).

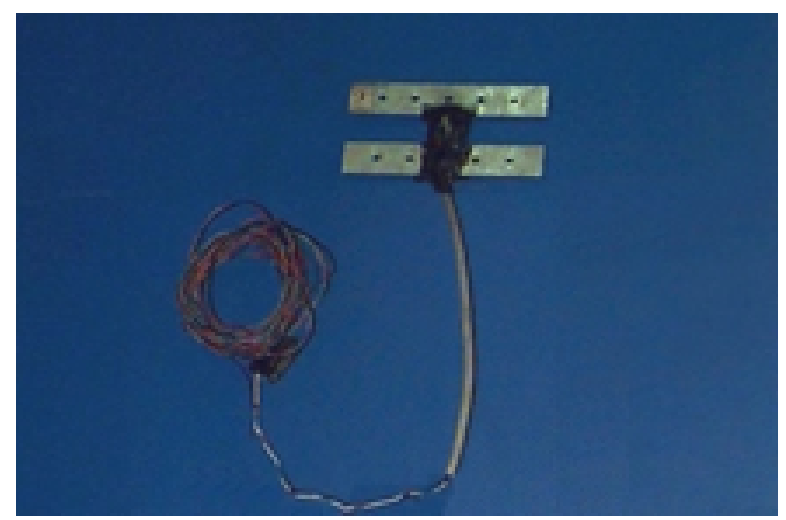

FIGURA 3.18 - Célula de carga 
Estas células foram construídas para trabalharem à tração e baseiam-se no princípio de que quando um corpo é submetido a um carregamento e sofre deformação, um extensômetro elétrico colado ao mesmo apresenta uma variação relativa de resistência elétrica, proporcional à deformação sofrida pelo corpo.

No dimensionamento das células utilizadas neste trabalho, objetivou-se uma forma geométrica capaz de permitir a fixação das mesmas ao geotêxtil, bem como garantir condições de linearidade, sensibilidade e acurácia satisfatórias.

Após uma série de tentativas utilizando formas e dimensões variadas, as células foram então confeccionas de acordo com a configuração que apresentou os melhores resultados durante a fase de testes. A carga máxima de trabalho prevista para essas células é $1,4 \mathrm{kN}$, com uma sensibilidade de $0,2 \mu$ strain/ $\mathrm{N}$ e $0,75 \%$ de acurácia.

Todas as células foram construídas com forma de "I" a partir de uma chapa de aço inox-304 com 1mm de espessura, ligando-se os extensômetros em ponte completa. A Figura 3.19 apresenta um esquema das referidas células de carga bem como a disposição dos strain gages nas mesmas. Os extensômetros $\mathrm{R}_{2}$ e $\mathrm{R}_{4}$ foram instalados na direção de aplicação da carga, enquanto os demais perpendicularmente à esta.

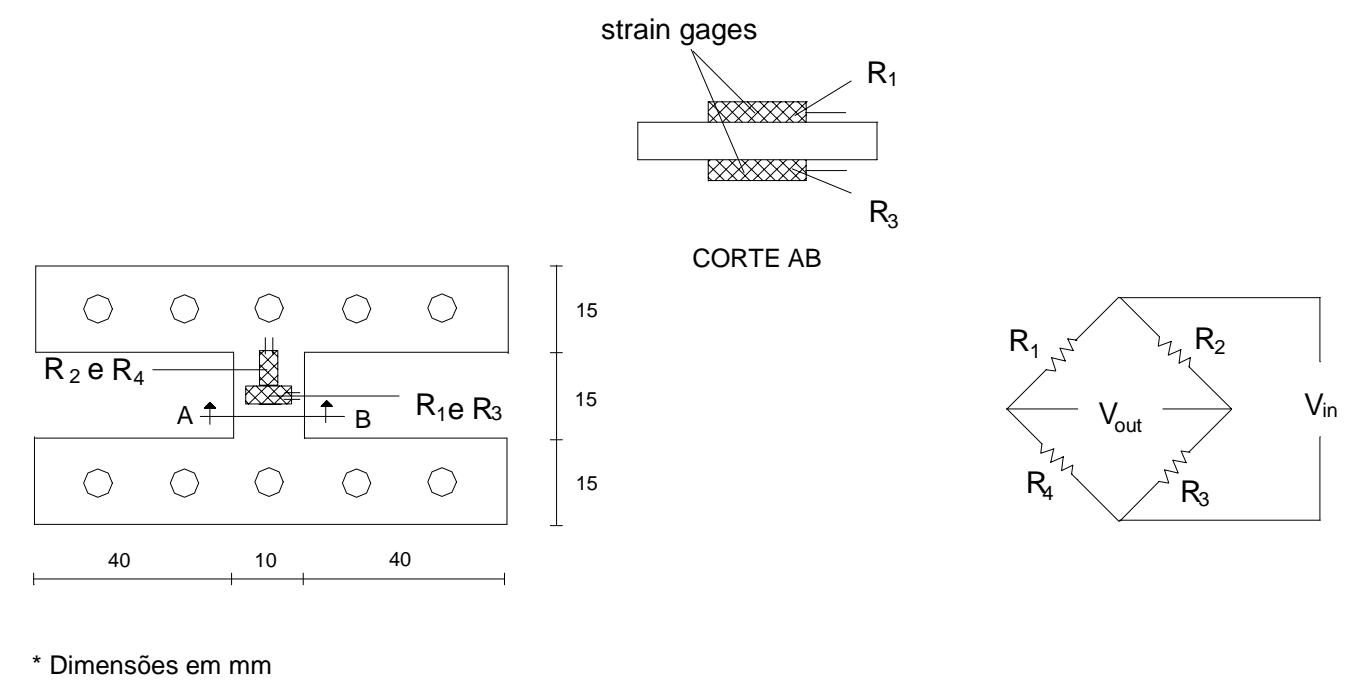

FIGURA 3.19 - Esquema de uma célula carga

Os strain gages utilizados foram os da EXCEL- Engenharia de Sensores Ltda, modelo PA09062AB-120-LEN para aço inox, com resistência de 120 ohms e 
um fator de sensibilidade de 2,12. Para as leituras das deformação específicas dos strain gages, utilizou-se um indicador de deformações da marca Transdutec, modelo T.832, com capacidade de leitura de $\pm 50000 \mu$ strain e resolução de $1 \mu$ strain.

Para garantir proteção mecânica e contra umidade, foi utilizada uma resina do mesmo fabricante dos extensômetros empregados, designada por resina silicone RK. Este produto é constituído por um líquido viscoso, que se polimeriza rapidamente em contato com o ar atmosférico, transformando-se numa camada de borracha silicone. Além desse procedimento, a região onde os strain gages foram colados foi reforçada com uma camada de araldite e envolvida por fita isolante.

A instrumentação do corpo de prova envolve, além da fixação das células de carga, a adição de mais seis peças de aço inox em forma de I, semelhantes às usadas na cofecção das células, sem no entanto possuírem strain gages. Duas são colocadas como mostra a Figura 3.20, ao passo que as quatro restantes encontram-se posicionadas na outra face do geotêxtil, sobrepostas às peças em I e às células de carga visíveis na Figura 3.20.

A fim de garantir a transferência de carga exclusivamente através das peças em I e das células de carga, as regiões reforçadas sofrem um corte nas posições indicadas tanto na Figura 3.20, para o caso de um corpo de prova preparado para um ensaio de fluência, quanto na Figura 3.21 para o caso de uma célula de carga sendo calibrada.

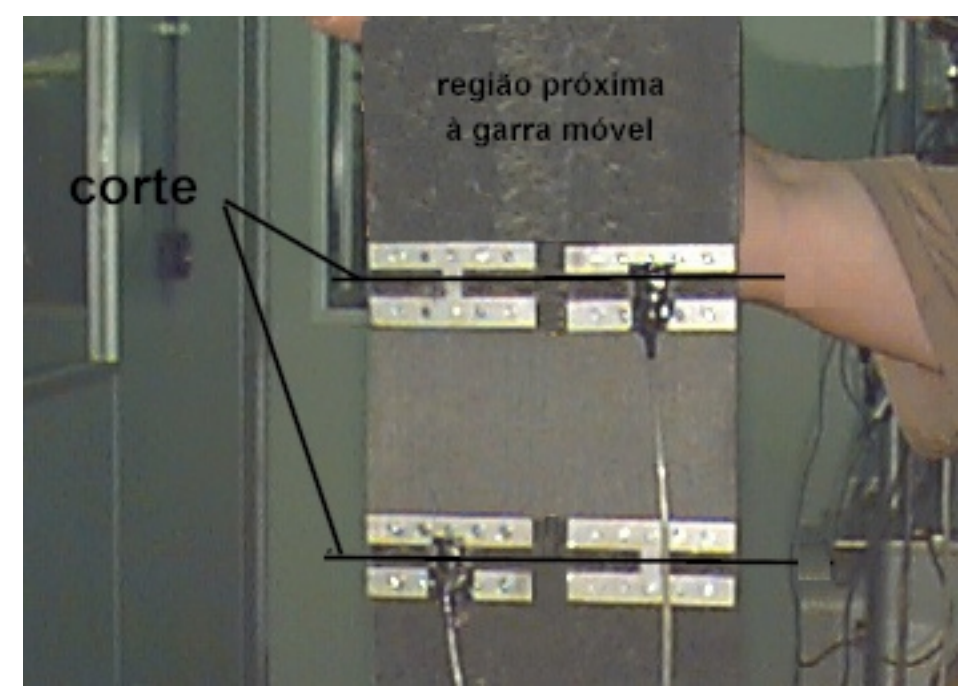

FIGURA 3.20 - Células de carga fixadas no geotêxtil 


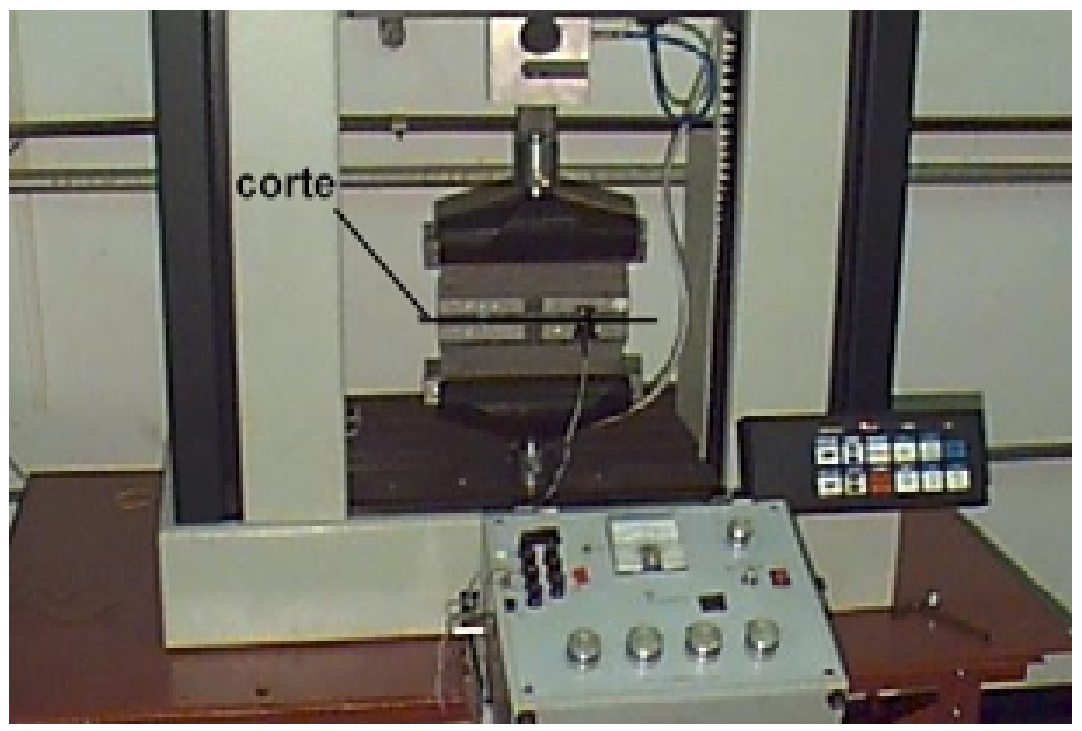

FIGURA 3.21 - Calibração de uma célula de carga

\subsubsection{Verificação da carga atuante no corpo de prova}

Diversos entraves foram encontrados durante a fase de calibração do equipamento de fluência confinada, no entanto, a manutenção da carga aplicada ao longo do comprimento do corpo de prova manifestou-se como a maior dificuldade a ser superada. A Figura 3.22 apresenta algumas configurações de ensaios adotadas na tentativa de se confinar o geotêxtil entre duas camadas de solo.

O solo utilizado nestes testes foi uma areia preparada por peneiramento a partir de um amostra extraída no porto de areia Munhoz localizado às margens do rio Mogi-Guaçu, próximo a rodovia Eng. Thales de L. Peixoto Júnior (SP-318). O peneiramento foi realizado a fim de separar as frações de areia fina e de pedregulho presentes no material original e obter assim, um solo contrastante com um outro, bastante argiloso e com o qual também se pretendia inicialmente, realizar ensaios de fluência.

No que concerne ao material empregado, o mesmo é constituído por cerca de $65 \%$ de areia grossa e $35 \%$ de areia média, tendo por base a escala granulométrica da ABNT. Ensaios para determinação dos índices de vazios máximo e mínimo forneceram $\mathrm{e}_{\operatorname{máx}}=0,840$ e $\mathrm{e}_{\min }=0,533$.

Para todas as disposições adotadas, utilizou-se camadas de solo com $20 \mathrm{~mm}$ de espessura, preparando-se a areia com uma compacidade relativa de $70 \%$ com o 
auxílio de um soquete, sendo a pressão confinante aplicada igual a $75 \mathrm{kPa}$. Ensaios de cisalhamento direto com o material nas mesmas condições de compacidade anteriormente descritas revelaram um ângulo de atrito interno de $44^{0}$. As características do geotêxtil empregado para essas análises podem ser encontradas na Tabela 3.1 (geotêxtil B).

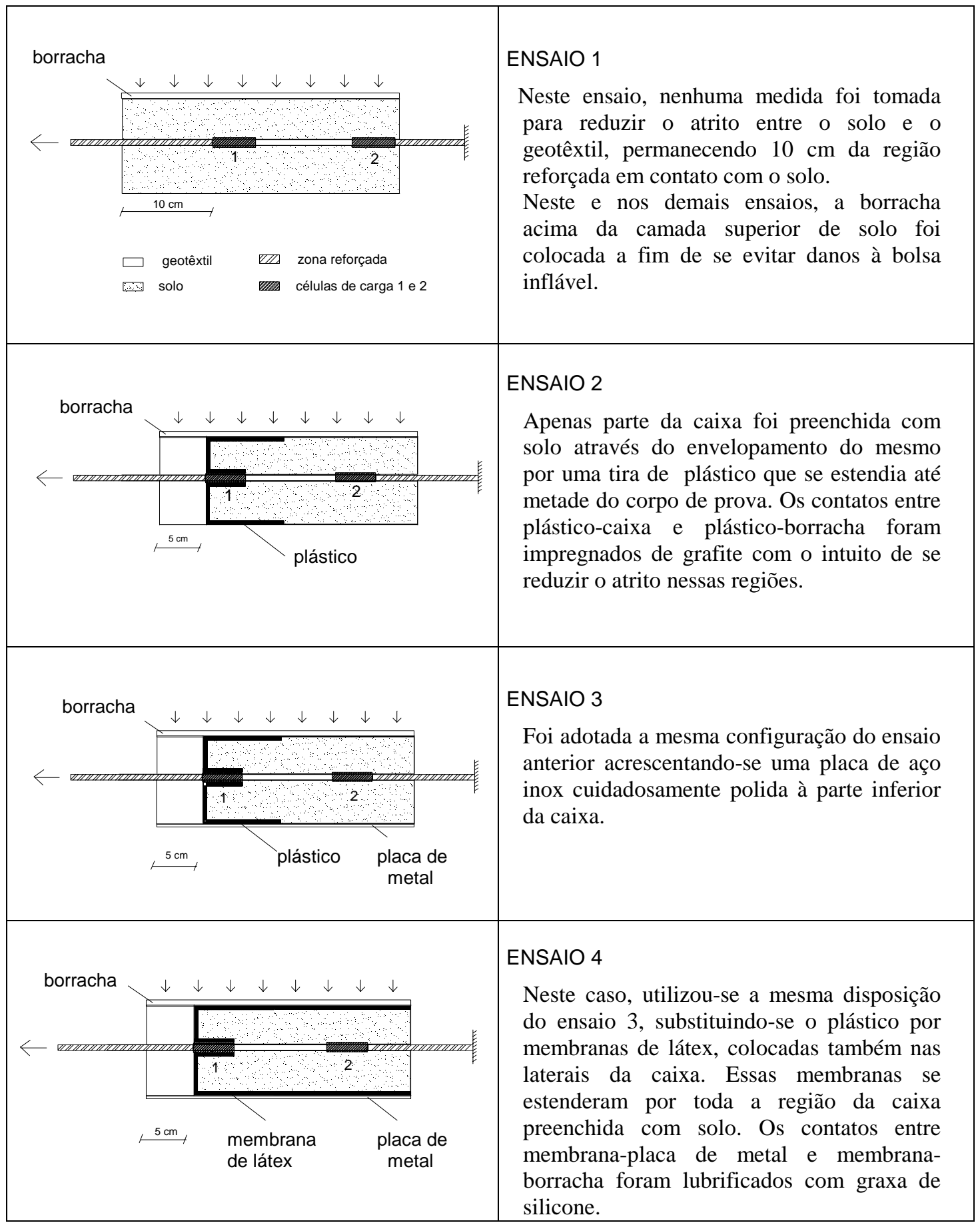

FIGURA 3.22 - Configurações de alguns testes realizados 
A Tabela 3.4 apresenta resultados obtidos para os diferentes arranjos encontrados na Figura 3.22. Por serem ensaios preliminares e não propriamente ensaios de fluência, os valores medidos pelas células de carga assim como os deslocamentos obtidos apresentados nessa tabela são referentes ao primeiro minuto após carregamento, não tendo sido monitorados ao longo do tempo, com exceção do ensaio 4 cujas leituras de carga e deslocamento se estenderam por 30 horas.

Nestes testes, utilizou-se o sistema de medidas internas de deslocamento, assim, os valores presentes na Tabela 3.4 correspondem ao deslocamento da haste maior fixada no ponto 1 (ver Figura 3.13).

TABELA 3.4 - Resultados obtidos para os ensaios apresentados na Figura 3.22.

\begin{tabular}{c|c|c|c|c|c}
\hline \multirow{2}{*}{ Ensaio } & $\begin{array}{c}\text { Carga Aplicada } \\
(\mathbf{k N})\end{array}$ & \multicolumn{2}{|c|}{$\begin{array}{c}\text { Carga Medida } \\
(\mathbf{k N})\end{array}$} & $\begin{array}{c}\text { *Carga Perdida } \\
(\mathbf{k N})\end{array}$ & $\begin{array}{c}\text { Deslocamento } \\
(\mathbf{m m})\end{array}$ \\
\cline { 3 - 4 } & & Célula 01 & Célula 02 & & \\
\hline 01 & 1,17 & 0,17 & 0,07 & 0,10 & 0,86 \\
02 & 1,17 & 1,14 & 0,32 & 0,84 & 6,20 \\
03 & 1,07 & 0,41 & 0,17 & 0,24 & 2,85 \\
04 & 1,07 & 1,02 & 0,85 & 0,17 & 20,73 \\
\hline
\end{tabular}

* Carga perdida ao longo do corpo de prova

Com relação à carga aplicada e ao valor medido internamente à caixa, observa-se uma variação de comportamento entre os ensaios, sendo o caso 1 o que apresentou uma maior discrepância entre esses valores. Esse resultado já era esperado em virtude da ação conjunta do atrito ao longo da zona reforçada e de alguma resistência passiva agindo na primeira célula de carga. O envelopamento do solo mostrou-se eficiente para evitar perda de carga até o início do corpo de prova, sendo o desempenho deficiente evidenciado pelo caso 3, em virtude, possivelmente, do deslizamento observado entre o plástico e a célula de carga através de uma inspeção visual realizada após ensaio.

Em todos os casos, com exceção do ensaio 4, percebe-se uma diminuição significativa da carga ao longo do corpo de prova em relação ao valor medido pela célula 1. Para os três primeiros casos, pode-se notar também, uma relação crescente entre a carga observada na primeira célula e a perda de carga que acontece ao longo do corpo de prova. Tal comportamento pode ser justificado pelo aumento do 
deslocamento à medida que cresce a carga na célula 1, uma vez que maiores deslocamentos relativos solo-geotêxtil implicam maiores mobilizações das forças de atrito.

Apesar da configuração adotada no caso 4 ter apresentado um bom resultado imediato, já que $83 \%$ da carga registrada na célula 1 foi detectada pela segunda célula de carga, essa disposição não solucionou o problema a longo prazo. $\mathrm{O}$ acompanhamento das cargas nas extremidades do corpo de prova revelou após 30 horas, uma redução de $14 \%$ da carga registrada inicialmente pela célula 2 .

Esses resultados denotam a imensa dificuldade para garantir compatibilidade de deformação entre solo e geotêxtil. Por mais que se tente reduzir os efeitos do atrito durante a realização dos ensaios, parece impossível suprimi-los por completo e as tentativas nesse sentido parecem implicar a adoção de uma metodologia de ensaio de difícil execução. Além dessas questões, as configurações expostas na Figura 3.22 ainda podem apresentar problemas como fendilhamento do solo e curvatura do corpo de prova, caso a superfície da camada inferior de solo se torne abaulada.

Diante deste panorama, optou-se por simplificar a configuração dos ensaios com confinamento, realizando-os sem a presença de solo (Figura 3.23), inserindo-se para tanto, o corpo de prova em uma membrana de látex lubrificada e colocando-se, para apoio do mesmo, uma base rígida composta por um bloco de madeira recoberto por um placa de aço inox extremamente polida. Ensaios testes realizados de acordo com essa proposta alternativa comprovaram tratar-se de uma solução viável em alguns casos, como será discutido no capítulo seguinte.

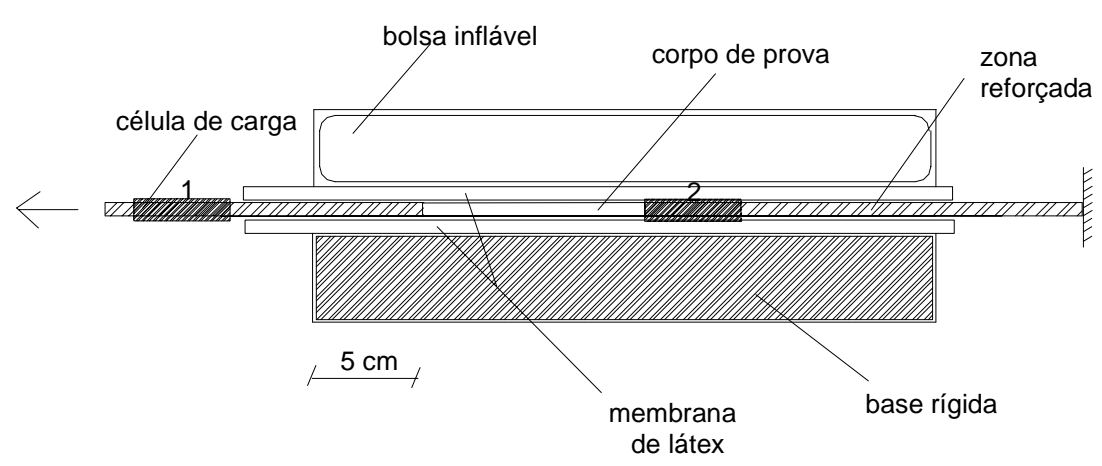

FIGURA 3.23 - Esquema de ensaios de fluência confinada com membrana 
Esse tipo de modificação já havia sido sugerida por LING et al. (1992) para ensaios de tração confinada, uma vez que os resultados encontrados por esse autores demonstram boa concordância entre ensaios realizados com confinamento em solo e com membranas para geotêxteis não-tecidos.

\subsubsection{Geotêxtil utilizado}

O geotêxtil que apresentou maiores deformações totais ao longo do tempo nos ensaios não-confinados foi empregado nesta segunda fase do trabalho. Assim, todos os ensaios confinados foram realizados utilizando-se o geotêxtil $B$, cujas características foram apresentadas anteriormente (Tabela 3.1).

No entanto, em virtude do término das amostras enviadas pelos fabricantes por ocasião dos ensaios não-confinados, uma nova bobina foi fornecida, sendo portanto realizada mais uma série de ensaios de gramatura e tração de faixa larga com esse novo material, também nesse caso, segundo a ABNT. Os resultados indicaram uma gramatura de $291 \mathrm{~g} / \mathrm{m}^{2}$, uma resistência máxima de 13,5 kN/m e 78\% de deformação na ruptura e serviram obviamente, para o cálculo das cargas a serem aplicadas nesta etapa dos ensaios de fluência.

\subsubsection{Ensaios realizados}

Todos os ensaios confinados foram realizados de acordo com a configuração apresentada na Figura 3.23, ou seja, apenas com membranas. Para evitar que a variabilidade do próprio geotêxtil interferisse na análise dos resultados, efetuou-se mais de um ensaio sob condições idênticas, tendo-se utilizado, no entanto, células de carga apenas no primeiro ensaio. A Tabela 3.5 apresenta os ensaios confinados realizados.

TABELA 3.5 - Ensaios confinados

\begin{tabular}{c|c|c|c|c|c}
\hline Designação & Geotêxtil & $\begin{array}{c}\text { Carga Aplicada } \\
\text { (\% da resistência à tração) }\end{array}$ & Pressão & Quantidade & Duração \\
\hline C1 & B & $40 \%$ & $50 \mathrm{kPa}$ & 3 & 100 horas \\
C2 & B & $40 \%$ & $150 \mathrm{kPa}$ & 3 & 100 horas \\
\hline
\end{tabular}




\subsubsection{Preparação dos corpos de prova}

Para obtenção dos corpos de prova, assim como nos ensaios não-confinados, primeiramente procedeu-se à amostragem da bobina fornecida pelo fabricante, também de acordo, com as recomendações da ABNT (NBR 12593). Como resultado, amostras com $200 \mathrm{~mm}$ de largura e $750 \mathrm{~mm}$ de comprimento foram obtidas, fazendose mais uma vez, com que a direção de aplicação da carga coincidisse com a direção de fabricação da bobina.

Duas regiões de uma amostra assim obtida eram reforçadas por impregnação da resina epoxi, uma com $200 \mathrm{~mm}$ de comprimento e a outra com $450 \mathrm{~mm}$ (regiões 1 e 2, respectivamente, mostradas na Figura 3.13). Essa resina composta pela mistura de araldite M e endurecedor HY956 era preparada na proporção 5:1 em massa e aplicada nas duas faces do geotêxtil através de um pincel, permanecendo a amostra em repouso por no mínimo 24 horas. Após esse período, eram feitas perfurações circulares com uma furadeira elétrica para a passagem dos parafusos das garras e das células de carga.

Por fim, após a colocação das células de carga, o geotêxtil era envolvido pela membrana de látex (Figura 3.24), fixando-se a mesma com fita adesiva. Toda a membrana era envolvida pela fita, com exceção da região em contato com a zona não reforçada do geotêxtil (Figura 3.25), podendo acompanhar então, as deformações do corpo de prova.

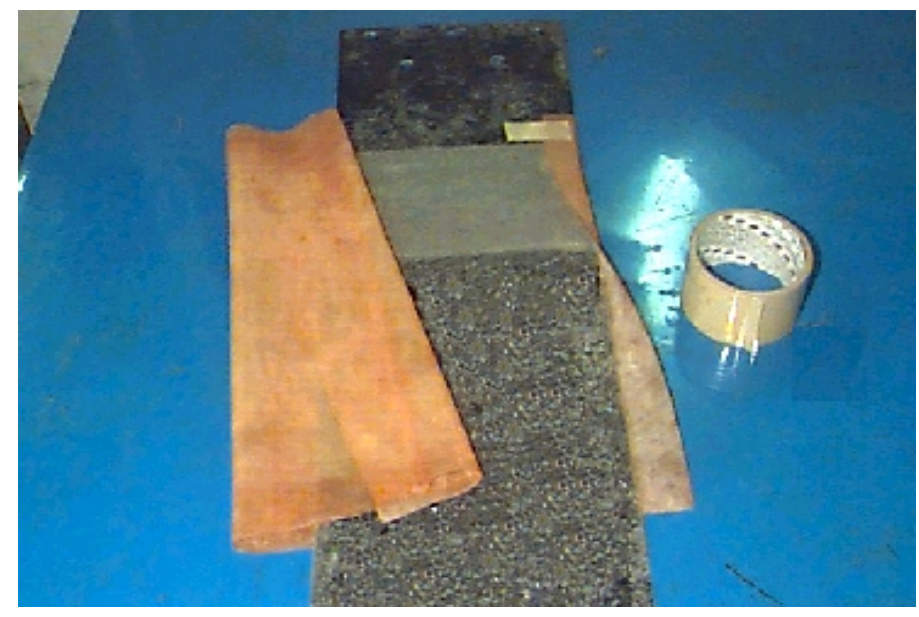

FIGURA 3.24 - Colocação da membrana 


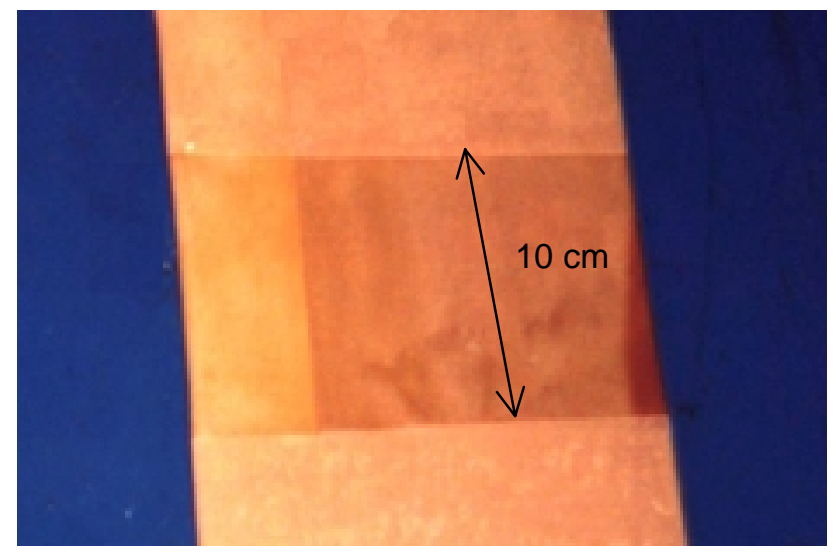

FIGURA 3.25 - Membrana já fixada

Como os geotêxteis foram confinados sem a presença de solo, considerou-se importante investigar o efeito de uma possível penetração de partículas de solo na manta. Para tanto, alguns ensaios foram realizados com pequenas modificações na preparação dos corpos de prova. Essas modificações envolveram dois processos distintos, ambos com a utilização de um solo argiloso proveniente da região de São Carlos.

Com relação a esse solo, a análise granulométrica realizada de acordo com a ABNT revelou tratar-se de um material com cerca de $65 \%$ de argila, $13 \%$ de silte e $22 \%$ de areia. A Figura 3.26 apresenta a curva granulométrica do referido solo. Os resultados dos demais ensaios efetuados encontram-se na Tabela 3.6, tendo sido realizados de acordo com o que preconizam as normas brasileiras vigentes.

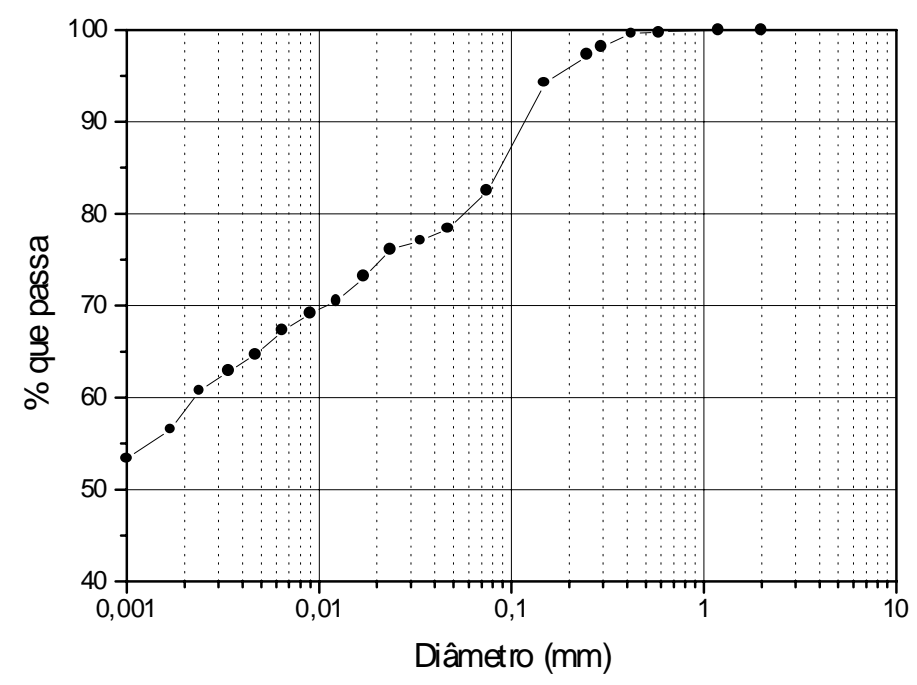

FIGURA 3.26 - Curva granulométrica do solo argiloso 
TABELA 3.6 - Caracterização do solo argiloso

\begin{tabular}{cc|c}
\hline$\gamma_{\mathrm{s}}$ & $\left(\mathrm{kN} / \mathrm{m}^{3}\right)$ & 29,42 \\
$\gamma_{\mathrm{dmax}}$ & $\left(\mathrm{kN} / \mathrm{m}^{3}\right)$ & 15,57 \\
$\mathrm{~W}_{\mathrm{ot}}$ & $(\%)$ & 27 \\
$\mathrm{LL}$ & $(\%)$ & 52 \\
$\mathrm{LP}$ & $(\%)$ & 35 \\
$\mathrm{IP}$ & $(\%)$ & 17 \\
\hline
\end{tabular}

No que diz respeito aos processos utilizados, o primeiro, consistia em compactar uma camada de solo até metade da caixa de ensaio (20 $\mathrm{mm}$ de espessura), colocar o geotêxtil com zonas já reforçadas e perfuradas e compactar uma nova camada até o topo da caixa. Nesse processo, o solo foi compactado através de um soquete, tentando-se atingir as condições de umidade ótima e peso específico seco máximo. Após esse procedimento, o corpo de prova era cuidadosamente retirado e submetido a um ensaio de fluência apenas com membrana. Essa proposta visava simular a impregnação de partículas que poderia ocorrer caso o ensaio fosse realizado confinando-se o geotêxtil entre duas camadas de solo.

O segundo processo envolvia a preparação de uma lama a partir do solo argiloso. A amostra de geotêxtil, já com regiões reforçadas e perfuradas para as garras, era depositada em um recipiente e essa lama era despejada sobre o corpo de prova em ambas as faces. Após se atingir um nível de impregnação satisfatório, considerado assim, por critérios meramente visuais e subjetivos, o mesmo permanecia em repouso até secar. Posteriormente, esse corpo de prova era ensaiado envolvido pela membrana.

Esse segundo procedimento simula uma condição extrema que não aconteceria em ensaios com o solo em questão e o geotêxtil, com intuito apenas de verificar o potencial que partículas de solo imbricadas na manta têm de interferir nas deformações a longo prazo dos geotêxteis. A Tabela 3.7 sintetiza os ensaios confinados realizados com modificações na preparação do corpo de prova. 
TABELA 3.7 - Ensaios confinados com modificações na preparação do corpo de prova.

\begin{tabular}{c|c|l|c|c|c|c}
\hline Designação & Geotêxtil & \multicolumn{1}{|c|}{ Processo } & $\begin{array}{c}\text { Carga Aplicada } \\
\text { (\% da resistência } \\
\text { à tração) }\end{array}$ & $\begin{array}{c}\text { Pressão } \\
\text { (kPa) }\end{array}$ & Quantidade & Duração \\
\hline C3 & B & 1.Compactação & $40 \%$ & 50 & 1 & 100 horas \\
C4 & B & 2. lama & $40 \%$ & 50 & 3 & 100 horas \\
\hline
\end{tabular}

\subsubsection{Montagem e execução dos ensaios}

Após a preparação do corpo de prova, tanto a membrana quanto a base rígida eram lubrificadas com graxa de silicone. $\mathrm{O}$ geotêxtil era então, depositado sobre a base rígida, colocando-se sobre o mesmo um pedaço de plástico liso também lubrificado com graxa de silicone na face em contato com a membrana. Com o geotêxtil preso às garras, a pressão era então aplicada, acoplando-se posteriormente, os relógios à garra móvel.

A bolsa inflável era alimentada por um compressor de ar que mantém uma rede de distribuição com cerca de $1.000 \mathrm{kPa}$ e que abrange diversos laboratórios do Departamento de Geotecnia da EESC. As pressões eram controladas por um conjunto de válvulas a partir de um ponto de distribuição da rede, próximo ao equipamento, sendo medidas através de um manômetro de mercúrio com capacidade máxima de $600 \mathrm{kPa}$ e resolução de $5 \mathrm{kPa}$.

No processo de aplicação da carga, utilizou-se exclusivamente o macaco hidráulico de $20 \mathrm{kN}$, sendo as condições de carregamento, bem como os tempos utilizados para as leituras do alongamento do corpo de prova semelhantes aos descritos anteriormente para o caso dos ensaios não-confinados.

Nos ensaios realizados com a presença de células de carga, foram efetuadas leituras de carga nos mesmos intervalos de tempo utilizados para as leituras dos relógios. 


\section{APRESENTAÇÃO E ANÁLISE DOS RESULTADOS}

\subsection{Apresentação dos resultados}

\subsubsection{Fluência não-confinada}

Os resultados concernentes aos ensaios de fluência não-confinada encontramse nas Figuras 4.1 a 4.5 e evidenciam o comportamento dos geotêxteis em termos da deformação total do corpo de prova ao longo do tempo, este último, plotado em escala logarítmica. Convém salientar que todos os ensaios cujos resultados são agora apresentados foram detalhados na Tabela 3.3.

As Figuras 4.1 a 4.3 são referentes aos ensaios de longa duração (superior a 7000 horas), realizados com o desígnio de se proceder a um reconhecimento geral da propensão à fluência dos geotêxteis utilizados. As Figuras 4.4 e 4.5 correspondem aos ensaios de curta duração (100 horas), sendo que cada gráfico expõe os resultados dos três ensaios efetuados com um mesmo geotêxtil e sob as mesmas condições de carregamento. $\mathrm{Na}$ fase de análise dos resultados, esses três ensaios serão representados por uma curva média (média das leituras de cada ensaio).

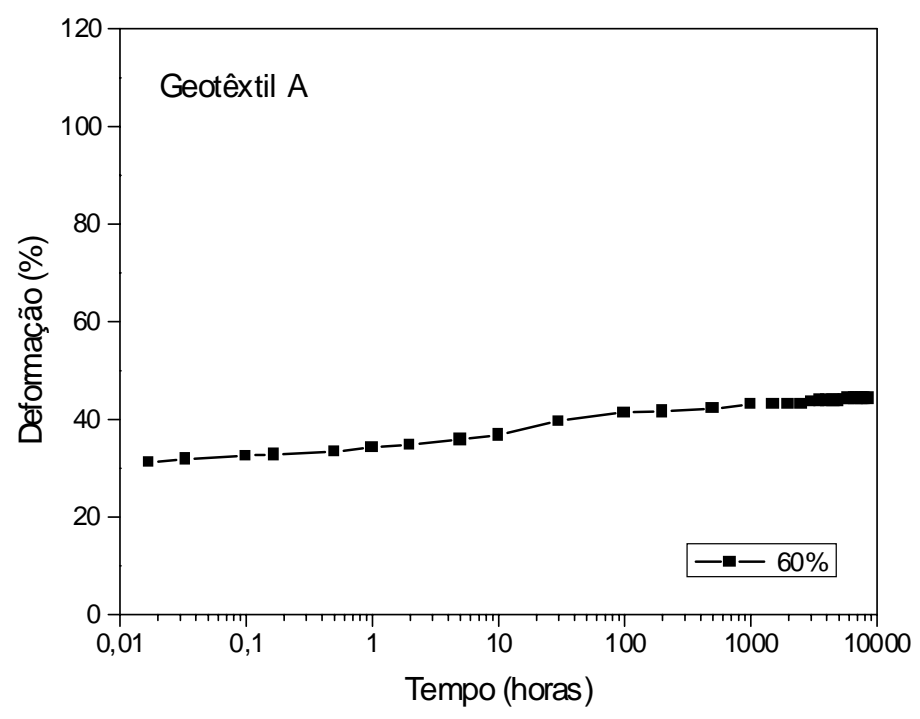

FIGURA 4.1 - Deformação total x tempo (ensaio NC1). 


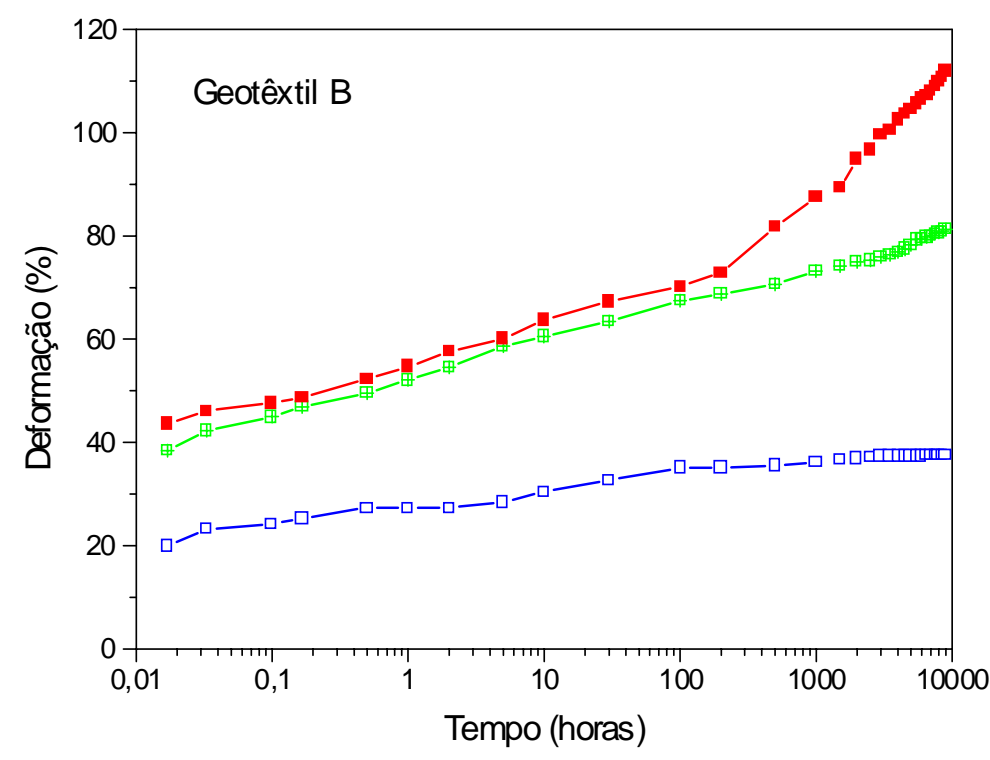

\begin{tabular}{lll}
\hline$\square-23 \%$ & 一甲一 $46 \%$ & - $-60 \%$ \\
\hline
\end{tabular}

FIGURA 4.2 - Deformação total x tempo (ensaios NC2, NC4 e NC5).

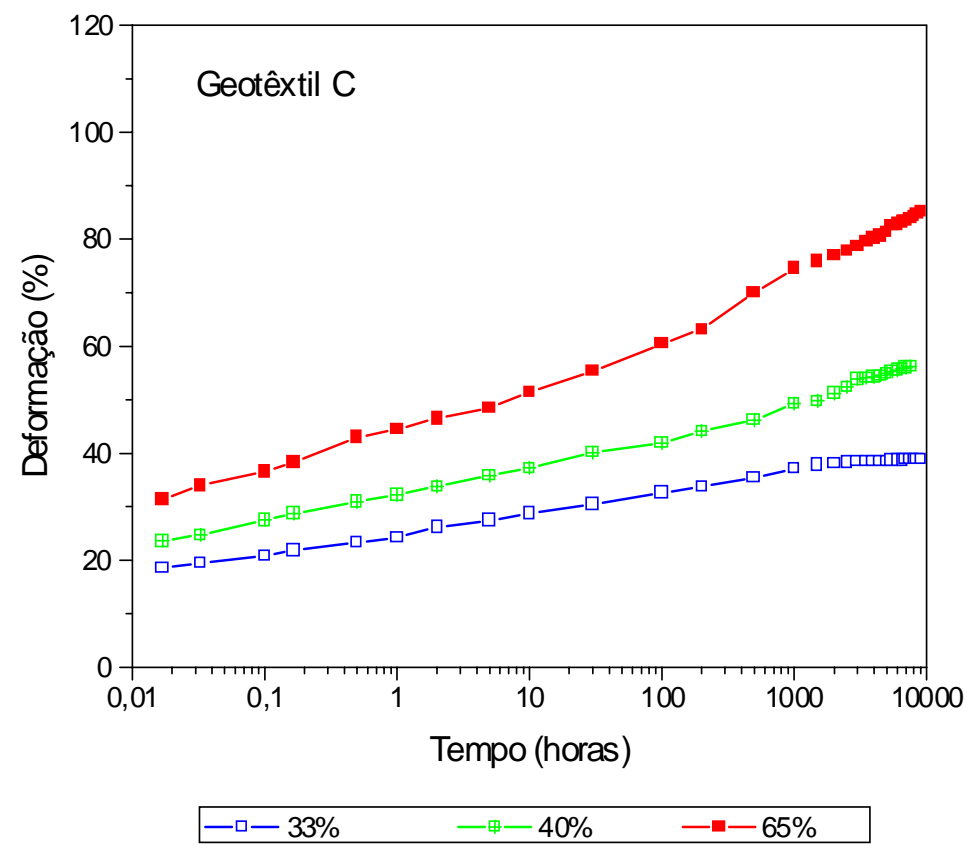

FIGURA 4.3 - Deformação total x tempo (ensaios NC6, NC8, NC9). 


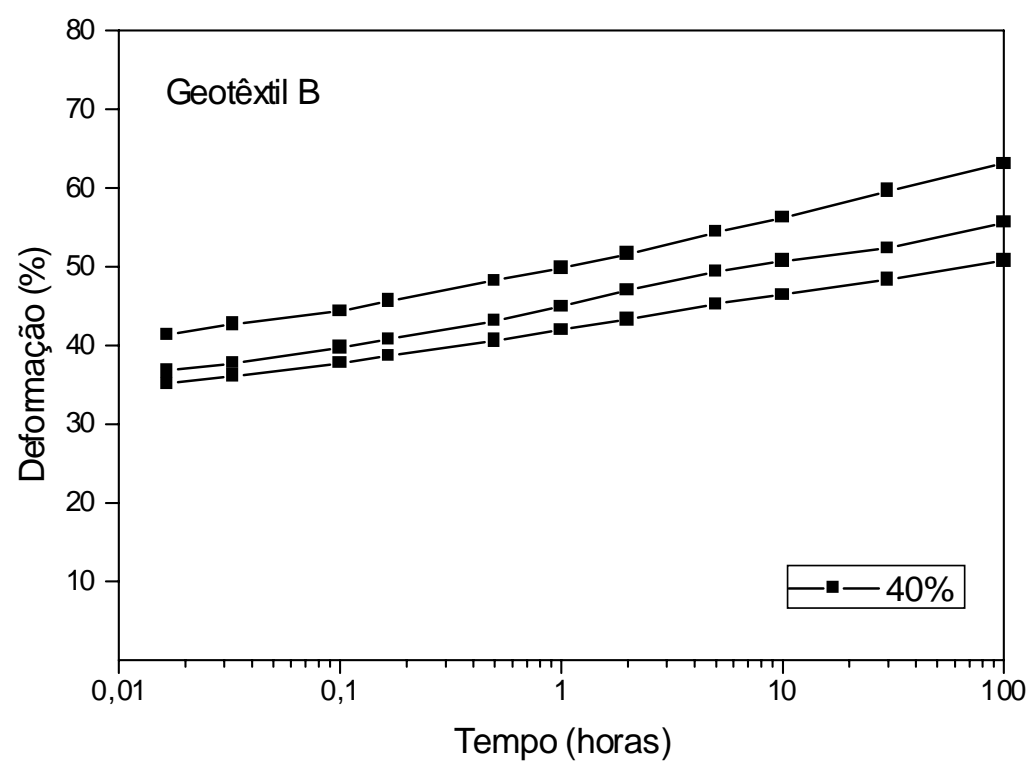

FIGURA 4.4 - Deformação total x tempo (ensaio NC3).

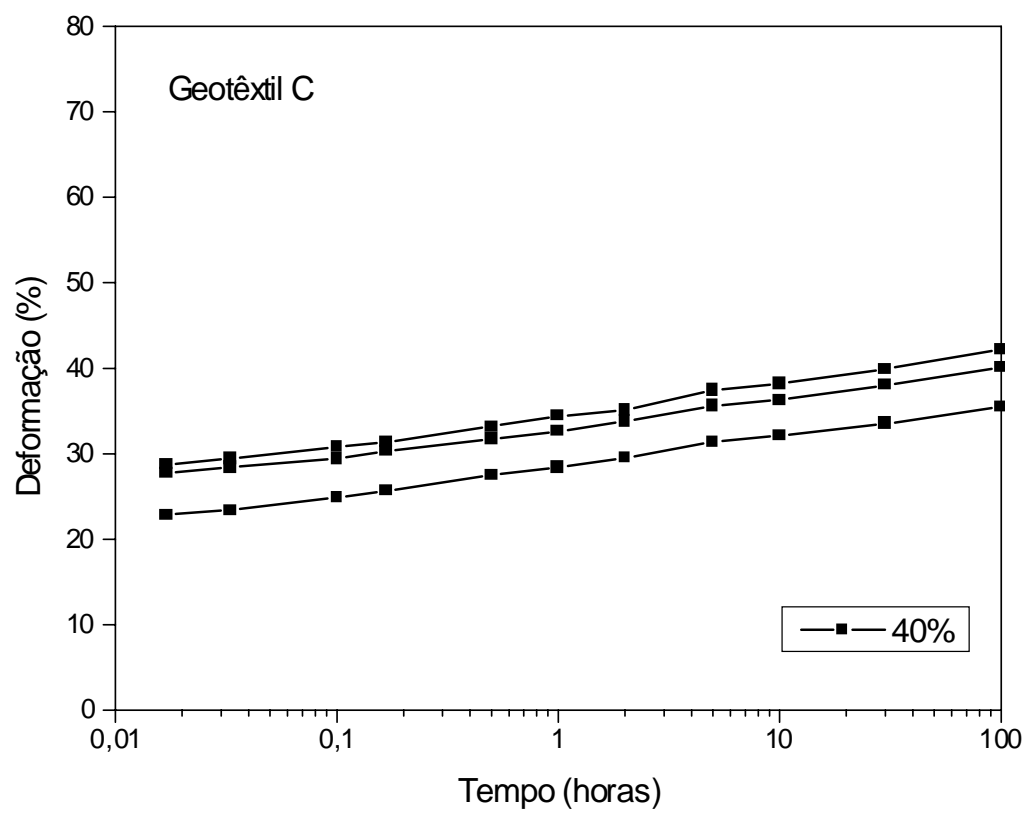

FIGURA 4.5 - Deformação total x tempo (ensaio NC7).

\subsubsection{Fluência confinada}

A respeito dos ensaios de fluência confinada (Tabelas 3.5 e 3.7), os resultados estão dispostos nas Figuras 4.6 a 4.9. Cada gráfico apresenta a deformação total ao longo do tempo e com exceção da Figura 4.8, expõe o produto dos três ensaios realizados sob as mesmas condições. Mais uma vez, para efeito de discussão dos 
resultados, esses ensaios repetidos serão sempre representados pela média dos pontos obtidos em cada ensaio.

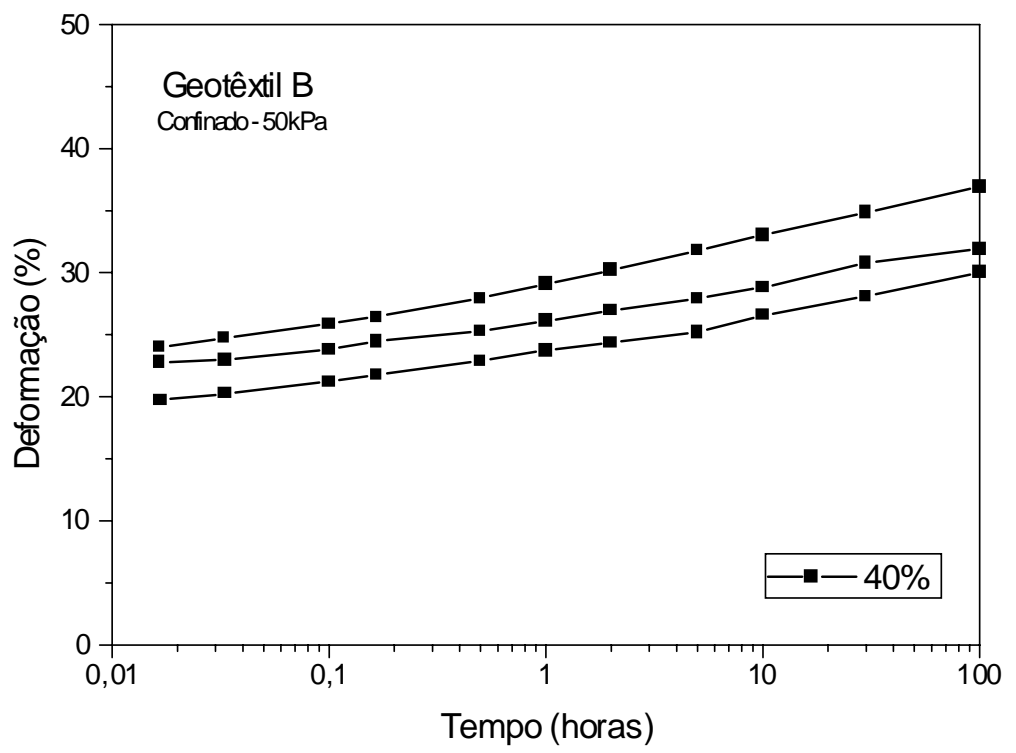

FIGURA 4.6 - Deformação total x tempo (ensaio C1).

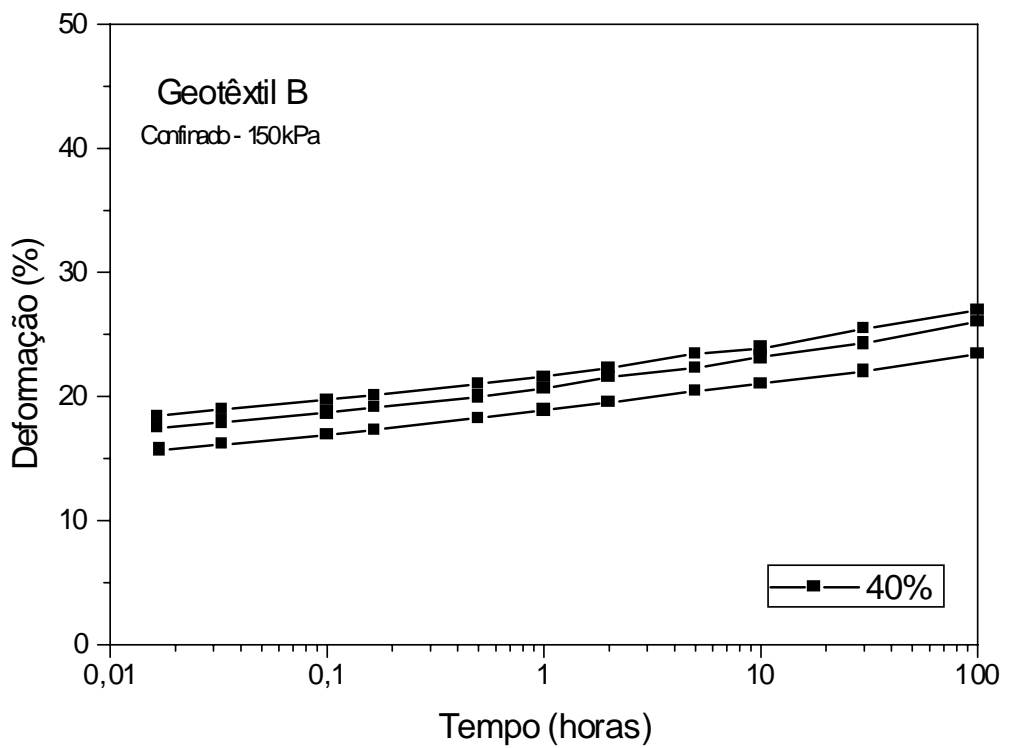

FIGURA 4.7 - Deformação total x tempo (ensaio C2). 


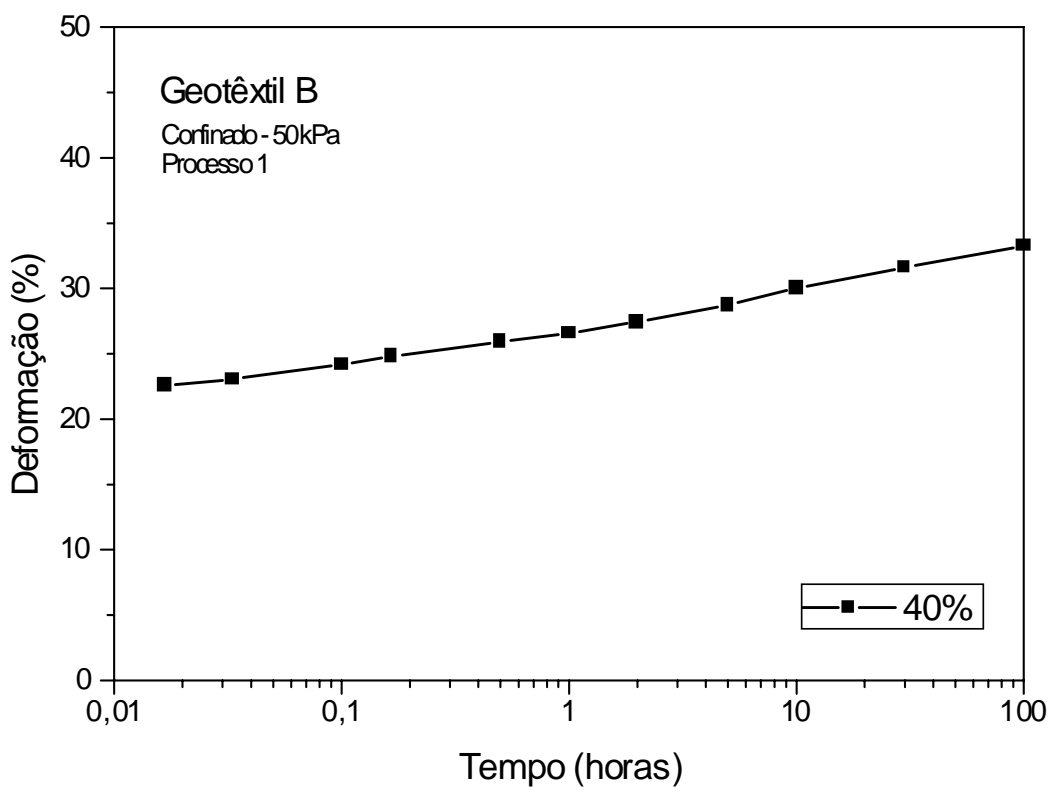

FIGURA 4.8 - Deformação total x tempo (ensaio C3).

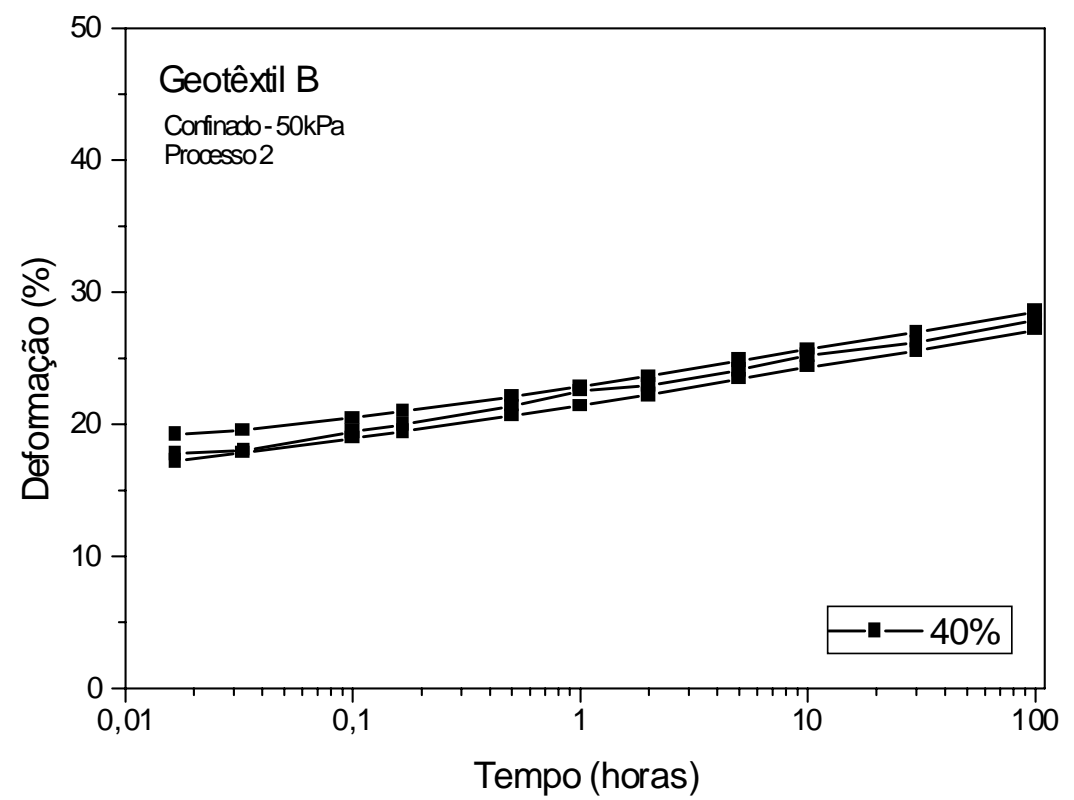

FIGURA 4.9 - Deformação total x tempo (ensaio C4). 


\subsection{Análise dos resultados}

\subsubsection{Fluência não-confinada}

Os ensaios não-confinados de longa duração realizados com os geotêxteis de polipropileno (Figuras 4.2 e 4.3) demonstraram o imenso potencial de fluência destes materiais, principalmente considerando os maiores níveis de carregamento. A Tabela 4.1 ilustra esse aspecto, expondo o acréscimo de deformação após 7500 horas, com relação ao valor apresentado no primeiro minuto de ensaio. Como se pode observar, o geotêxtil B chegou a sofrer um acréscimo de $150 \%$ para $60 \%$ da resistência à tração.

TABELA 4.1 - Acréscimo da deformação total entre 1 min e 7500 horas.

\begin{tabular}{c|c|c}
\hline Geotêxtil & $\begin{array}{c}\text { Carga Aplicada } \\
\text { (\% da resistência à tração) }\end{array}$ & Acréscimo da deformação \\
\hline \multirow{3}{*}{ B } & $23 \%$ & $88 \%$ \\
& $46 \%$ & $109 \%$ \\
& $60 \%$ & $150 \%$ \\
\hline \multirow{2}{*}{ C } & $33 \%$ & $77 \%$ \\
& $40 \%$ & $96 \%$ \\
& $65 \%$ & $119 \%$ \\
\hline
\end{tabular}

Nenhuma ruptura foi observada nestes ensaios, embora os geotêxteis B e C já tenham excedido, após 9000 horas, para as maiores cargas, cerca de 27 e 50\%, respectivamente, da deformação de ruptura obtida nos ensaios de tração. Segundo MSOUTI et al. (1997) esse comportamento parece ser característico em geotêxteis de polipropileno, para os quais a ruptura realmente ocorre com deformações superiores às encontradas nos ensaios de tração convencionais.

Para averiguar a influência da carga aplicada nas deformações ao longo do tempo, procedeu-se a um ajuste dos dados presentes nas Figuras 4.2 e 4.3, utilizandose a função logarítmica mostrada na expressão (4.1). Dessa forma, o coeficiente angular da reta assim gerada serve de parâmetro a fim de quantificar a susceptibilidade à fluência dos geotêxteis, considerando níveis distintos de carregamento.

$\varepsilon=a+b \log (\mathrm{t})$ 
onde,

$\varepsilon$ - deformação total em \%;

$\mathrm{t}$ - tempo em horas;

$\mathrm{a}, \mathrm{b}$ - constantes obtidas pelo ajuste.

As Figuras 4.10 e 4.11 apresentam os ajustes realizados, ao passo que os valores obtidos para as constantes a e b e os respectivos coeficientes de determinação $\left(\mathrm{R}^{2}\right)$ encontram-se na Tabela 4.2. Para os ensaios efetuados com as cargas mais elevadas (60\% e $65 \%$ para geotêxteis B e C, respectivamente), dois trechos das curvas com tendências distintas foram considerados, executando-se ajustes para cada intervalo.

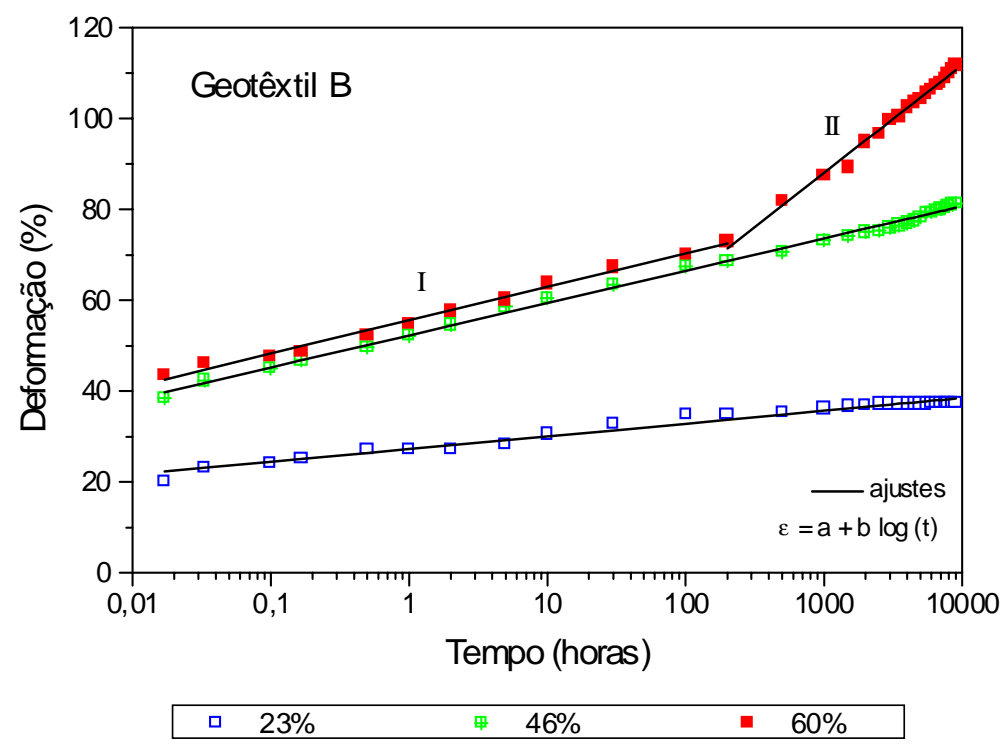

FIGURA 4.10 - Ajustes realizados para o geotêxtil B.

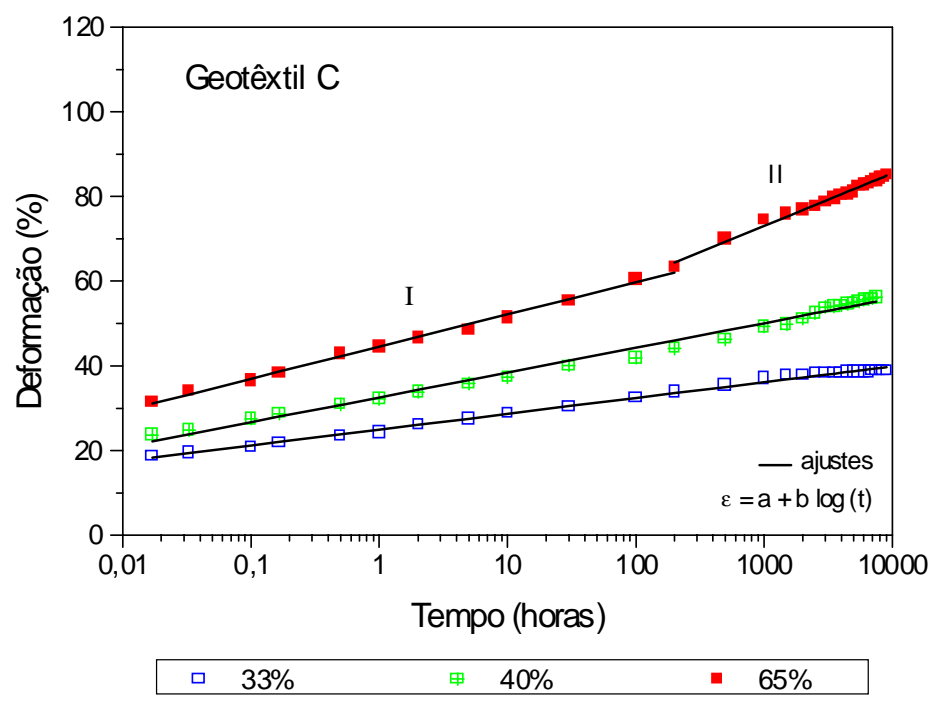

FIGURA 4.11 - Ajustes realizados para o geotêxtil C. 
TABELA 4.2 - Valores obtidos nos ajustes dos ensaios de longa duração para geotêxteis B e C.

\begin{tabular}{|c|c|c|c|c|c|}
\hline \multirow[t]{2}{*}{ Geotêxtil } & \multirow{2}{*}{$\begin{array}{c}\text { Carga Aplicada } \\
\text { (\% da resistência à tração) }\end{array}$} & \multirow[t]{2}{*}{ Trecho } & \multicolumn{2}{|c|}{ Constantes } & \multirow{2}{*}{$\begin{array}{c}\text { Coeficiente de } \\
\text { determinação }\left(\mathbf{R}^{2}\right)\end{array}$} \\
\hline & & & $\mathrm{a}$ & $\mathrm{b}$ & \\
\hline \multirow[t]{3}{*}{ B } & $\begin{array}{l}23 \% \\
46 \%\end{array}$ & $\begin{array}{l}- \\
-\end{array}$ & $\begin{array}{l}27,23 \\
52,28\end{array}$ & $\begin{array}{l}2,81 \\
7,10\end{array}$ & $\begin{array}{l}0,976 \\
0,997\end{array}$ \\
\hline & $60 \%$ & I & 55,56 & 7,35 & 0,992 \\
\hline & $60 \%$ & II & 16,81 & 23,73 & 0,993 \\
\hline \multirow{4}{*}{$\mathrm{C}$} & $33 \%$ & - & 24,92 & 3,73 & 0,995 \\
\hline & $40 \%$ & - & 32,52 & 5,85 & 0,990 \\
\hline & $65 \%$ & I & 44,52 & 7,62 & 0,995 \\
\hline & $65 \%$ & II & 35,72 & 12,44 & 0,990 \\
\hline
\end{tabular}

Os valores presentes na Tabela 4.2 demonstram a dependência entre a carga aplicada e a constante $\mathrm{b}$, denotando a relação crescente entre o nível de carregamento e as deformações ao longo do tempo. Para o geotêxtil B, quando o nível passa de $23 \%$ para $46 \%$, b aumenta cerca de 2,5 vezes, comparando-se os níveis de $46 \%$ e $60 \%$, o acréscimo de b foi inicialmente bastante reduzido (trecho I) até se tornar cerca de 3 vezes superior ao valor associado a $46 \%$ (trecho II). Para o geotêxtil C, o valor de b para um carregamento correspondente a $40 \%$ da resistência à tração apresentou um acréscimo de 1,5 vezes em relação ao nível de 33\%, a comparação entre $40 \%$ e $65 \%$ gera inicialmente, uma diferença entre os valores de b de 1,3 vezes, aumentando para cerca de 2,2 vezes ao se considerar o trecho II.

No que diz respeito ao tipo de polímero, a Figura 4.12 evidencia o melhor comportamento do geotêxtil de poliéster em relação ao de polipropileno, comprovando a influência marcante do polímero nas deformações a longo prazo desses materiais. Decorridas 1000 horas, o geotêxtil A sofreu um acréscimo na deformação apresentada no primeiro minuto de ensaio de cerca de 40\%, mantendo praticamente a mesma deformação nas próximas 7500 horas. O geotêxtil B sofreu neste mesmo período, um acréscimo de $100 \%$, não apresentando a tendência de estabilização observada para o geotêxtil de poliéster após 1000 horas.

$\mathrm{O}$ ajuste realizado através da eq. (4.1) para o geotêxtil A, revelou o seguinte resultado: $\mathrm{a}=34,97, \mathrm{~b}=2,47, \mathrm{R}^{2}=0,982$. Comparando os valores de $\mathrm{b}$ obtidos para 
os dois geotêxteis (ver Tabela 4.2 para geotêxtil B), pode-se dizer que a tendência de apresentar fluência foi inicialmente cerca de 3 vezes maior para o geotêxtil de polipropileno (trecho I), tornando-se aproximadamente 10 vezes superior após cerca de 200 horas (trecho II). Resultados semelhantes foram encontrados por LEVACHER et al. (1994) que relatam para geotêxteis de polipropileno, uma fluência cerca de 10 vezes superior a apresentada por geotêxteis de poliéster, em termos da inclinação da reta ajustada para os dados plotados em gráficos $\log (\varepsilon)-$ $\log (\mathrm{t})$.

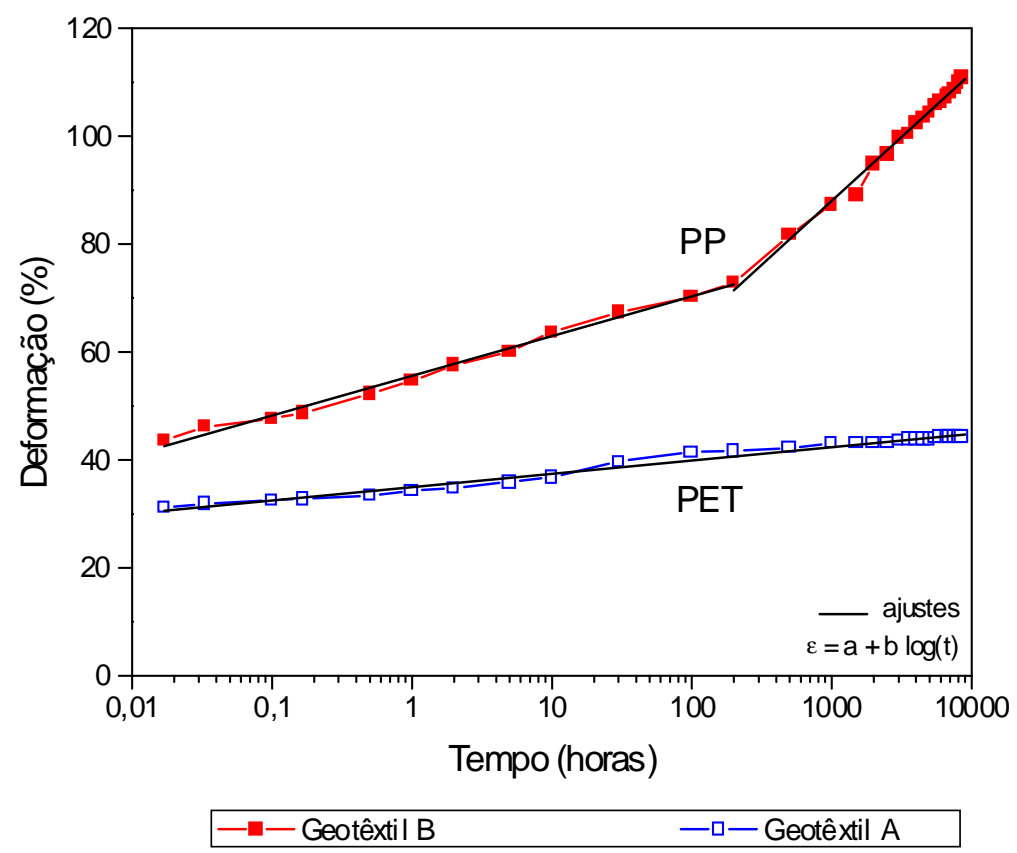

FIGURA 4.12 - Deformação total x tempo para geotêxteis de PET e PP com $60 \%$ de suas resistências à tração (ensaios NC1 e NC5).

Com relação aos ensaios de curta duração, a Figura 4.13 apresenta os ajustes realizados através da eq. (4.1) para os ensaios NC3 e NC7. Apesar de serem constituídos pelo mesmo tipo de polímero e ambos serem não-tecidos agulhados, o comportamento demonstrado por esses geotêxteis nas 100 horas de ensaio foi um pouco diferente. Os valores obtidos nos ajustes encontram-se na Tabela 4.3. 


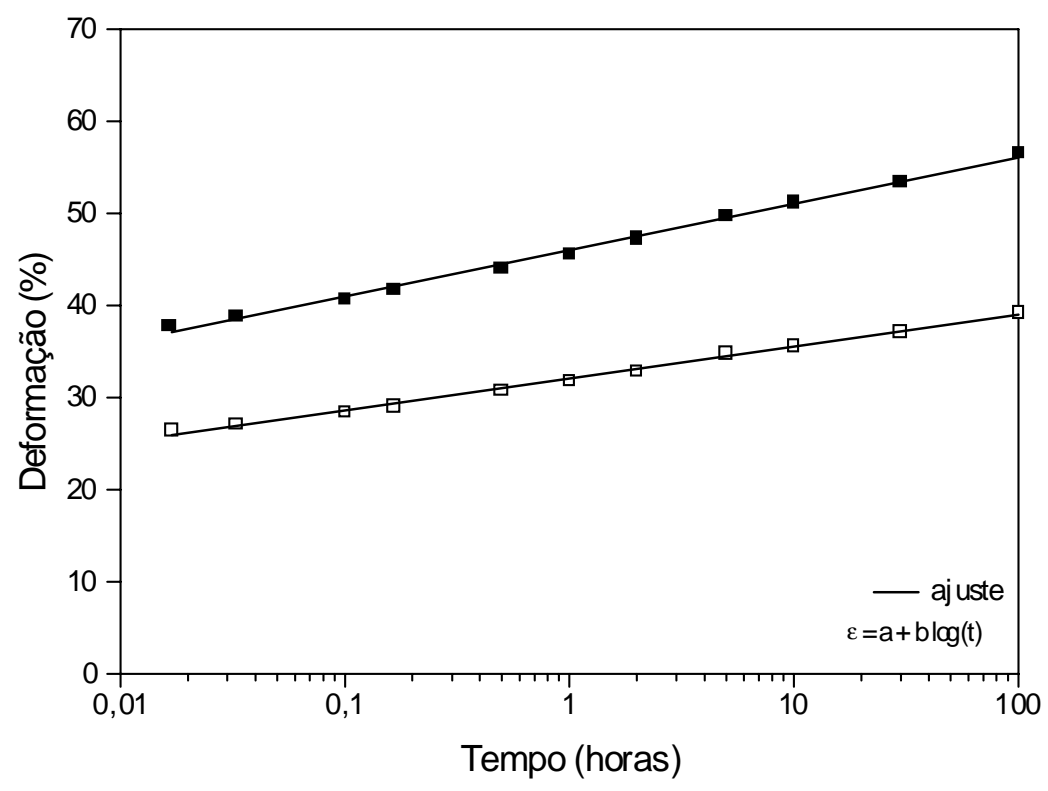

- Geotêxil B- $40 \%$

口 Geotêxil C - 40\%

FIGURA 4.13 - Comparação entre geotêxteis de polipropileno (ensaios NC3 e NC7).

TABELA 4.3 - Valores obtidos nos ajustes dos ensaios NC3 e NC7.

\begin{tabular}{c|c|c|c|c}
\hline \multirow{2}{*}{ Geotêxtil } & \multirow{2}{*}{$\begin{array}{c}\text { Carga Aplicada } \\
\text { (\% da resistência à tração) }\end{array}$} & \multicolumn{2}{|c|}{ Constantes } & $\begin{array}{c}\text { Coeficiente de } \\
\text { determinação (R }\end{array}$ \\
\cline { 3 - 4 } & & $\mathrm{a}$ & $\mathrm{b}$ & \\
\hline $\mathrm{B}$ & $40 \%$ & 45,99 & 5,03 & 0,996 \\
$\mathrm{C}$ & $40 \%$ & 32,05 & 3,47 & 0,996 \\
\hline
\end{tabular}

Considerando os dados da Tabela 4.3, percebe-se que para um carregamento correspondente a $40 \%$ de suas resistências à tração, o geotêxtil C apresentou uma fluência cerca de 1,4 vezes menor que o geotêxtil B. Diferenças no processo de fabricação, as quais são de domínio exclusivo dos fabricantes, devem provocar essa desigualdade e possivelmente, ocasionar também, os valores de deformação de ruptura bastante diferentes obtidos nos ensaios de tração.

\subsubsection{Fluência confinada}

Em alusão aos ensaios confinados, a presença do confinamento realmente reduziu as deformações totais apresentadas pelo geotêxtil ao longo do tempo, como 
mostra a Figura 4.14, para uma pressão de $50 \mathrm{kPa}$. Neste caso, para se proceder a análise em termos de fluência, o parâmetro b foi substituído pela taxa de deformação, embora conceitualmente ambas abordagens sejam semelhantes.

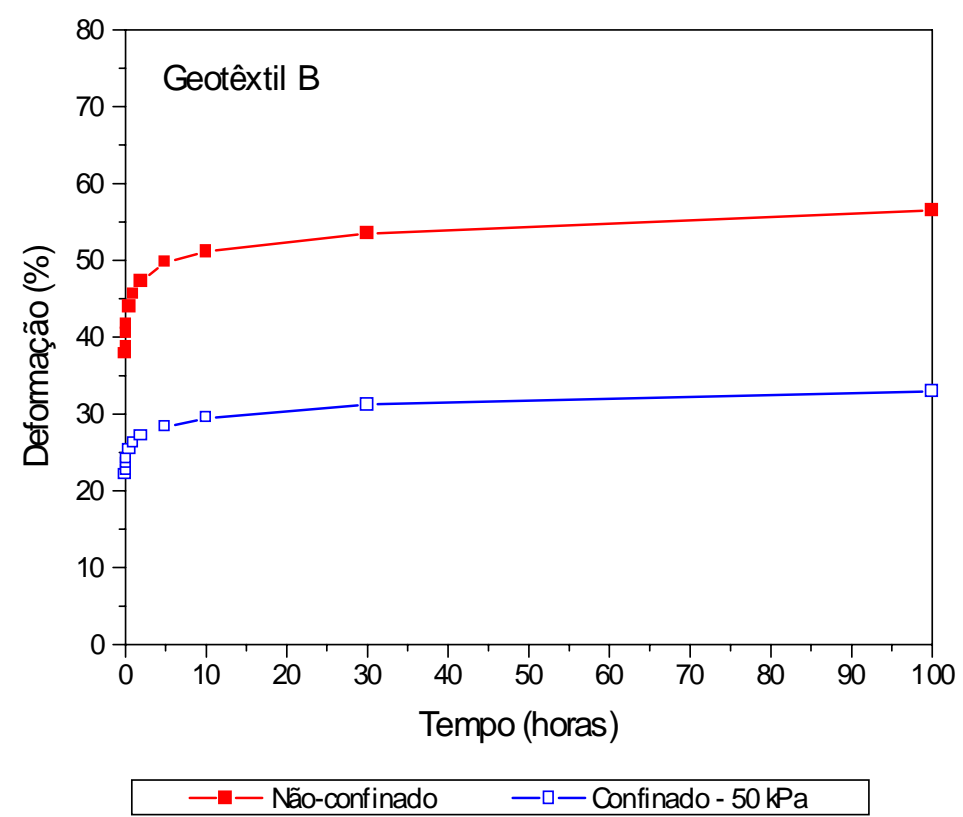

FIGURA 4.14 - Comparação entre ensaios não-confinados e confinados, $40 \%$ da resistência à tração (ensaios NC3 e C1).

A respeito da taxa de deformação, como é característico em ensaios de fluência, pode-se notar um rápido decréscimo nos primeiros minutos, percebendo-se também, sua redução com o confinamento. A Figura 4.15 expõe o que foi dito apresentando a variação da taxa de deformação com o tempo para os dois tipos de ensaio realizados. Comparando-se as taxas de deformação a cada instante, percebe-se que para a situação com confinamento as mesmas são cerca de 2,8 a 1,6 vezes menores em relação ao ensaio não confinado. Essa redução foi decrescente durante a primeira hora de ensaio e a partir de então, a relação entre as taxas sem e com confinamento manteve-se praticamente constante em torno de 1,6. 


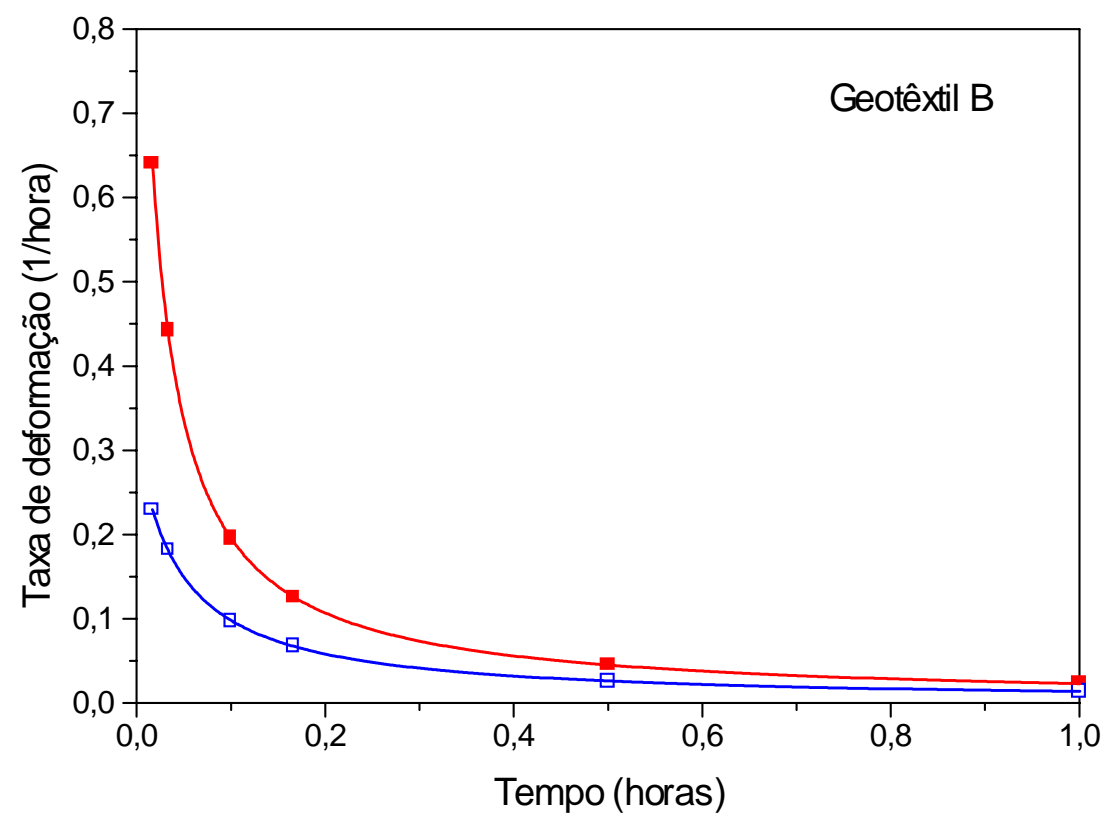

- Não-confinado $\quad \square \quad$ Confinado - $50 \mathrm{kPa}$

FIGURA 4.15 - Taxa de deformação x tempo, $40 \%$ da resistência à tração (ensaios NC3 e C1).

O cálculo da taxa de deformação foi realizado derivando-se uma função logarítmica ajustada aos dados da Figura 4.14. Esse ajuste forneceu coeficientes de determinação $\left(\mathrm{R}^{2}\right)$ iguais a 0,998 e 0,999 para a condição confinada e não-confinada, respectivamente. A expressão (4.2) indica o tipo de função logarítmica utilizada, enquanto a Tabela 4.4 apresenta os valores das constantes obtidas nos ajustes.

$\varepsilon=\mathrm{c}-\mathrm{d} \ln (\mathrm{t}+\mathrm{e})$

onde,

$\varepsilon$ - deformação total em \%;

$\mathrm{t}$ - tempo em horas;

$\mathrm{c}, \mathrm{d}, \mathrm{e}-$ constantes obtidas pelo ajuste.

TABELA 4.4 - Constantes obtidas nos ajustes dos ensaios NC3 e C1.

\begin{tabular}{c|c|c|c}
\hline Tipo de ensaio & c & d & e \\
\hline Não confinado & 45,64 & $-2,35$ & 0,02 \\
Confinado $-50 \mathrm{kPa}$ & 26,26 & $-1,43$ & 0,04 \\
\hline
\end{tabular}


Não obstante esse efeito do confinamento na fluência, observando-se a Figura 4.14 pode parecer inicialmente, que este aspecto ocupe uma posição secundária na redução das deformações totais, já que a diferença entre as mesmas, para os dois casos em questão, é em grande parte reflexo de uma mudança de comportamento apresentada já no primeiro minuto de ensaio. Após 100 horas, cerca de $65 \%$ da diferença de deformação total entre os ensaios sem e com confinamento foi manifestada na leitura correspondente a 1 minuto. Entretanto, não se pode perder de vista o tempo de vida útil das obras de solo reforçado com geotêxteis, assim, considerando um período de 100 anos e extrapolando os dados através da eq. (4.2), percebe-se que, neste caso, $50 \%$ da diferença entre as deformações totais deve-se à fluência, ratificando a importância de sua redução pela presença do confinamento (neste caso, considerou-se a leitura de 1 minuto como sendo correspondente à deformação imediata, apenas para fins de comparação).

Sobre a possibilidade do corpo de prova ficar submetido a uma carga inferior a que foi aplicada, nos ensaios confinados apenas com membranas, para $50 \mathrm{kPa}$, as células de carga 1 e 2 posicionadas conforme a Figura 3.23, indicaram uma diferença em suas leituras de $0,07 \mathrm{kN}$ (3,7\% do nível de carregamento aplicado). Considerando que todos os tipos de equipamento apresentam limitações, preferiu-se conviver com esse problema em vez de buscar algum tipo de solução que comprometesse a simplicidade da configuração dos ensaios. De qualquer forma, esse resultado não inviabiliza as discussões do efeito do confinamento anteriormente realizadas. Já para $150 \mathrm{kPa}$, o resultado não pôde ser considerado satisfatório, uma vez que a diferença entre as cargas registradas pelas duas células de carga foi $0,20 \mathrm{kN}$ (cerca de 18,5\% da carga aplicada).

Tendo em vista esse resultado, uma comparação direta entre os ensaios confinados para pressões de 50 e $150 \mathrm{kPa}$ com uma mesma carga aplicada (ensaios C1 e C2), embora fosse a intenção inicial, não parece adequada para verificar o possível aumento do efeito do confinamento na fluência, em virtude do acréscimo da pressão. Mesmo assim, a Figura 4.16 expõe os resultados dos ensaios para as duas situações, já que a curva correspondente a um ensaio C2, sem o problema da perda de carga, deve estar compreendida entre as curvas mostradas na Figura 4.16. 


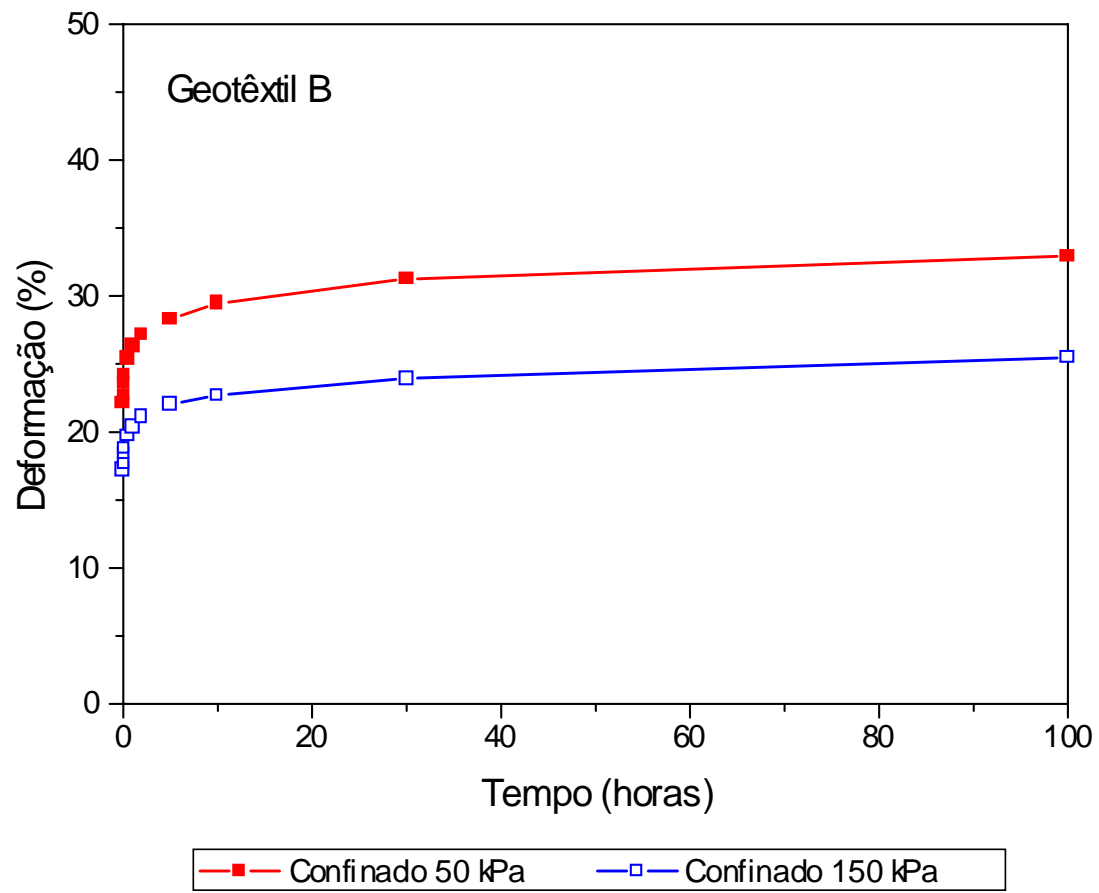

FIGURA 4.16 - Ensaios C1 e C2 (40\% da resistência à tração).

Ensaios confinados realizados com 50 e $150 \mathrm{kPa}$, utilizando-se uma maior gramatura e aplicando-se cargas mais elevadas poderiam possibilitar uma comparação direta entre essas duas condições, no entanto, comprometeriam o cronograma do trabalho, motivo pelo qual não foram realizados. A mundança de gramatura ficaria condicionada, é claro, à comprovação de que esta não altera a fluência do geotêxtil utilizado.

Acerca dos ensaios conduzidos com tentativas de impregnação de solo na manta, a Figura 4.17 possibilita comparar os resultados encontrados.

Considerando o primeiro processo, os resultados, bem como uma inspeção visual do corpo de prova, demonstraram que a impregnação de solo na manta pelo processo de compactação pode ser considerada desprezível e pelo menos para esse solo, o mesmo resultado seria obtido em ensaios de fluência, confinando-se ou não, o geotêxtil entre camadas de solo. 


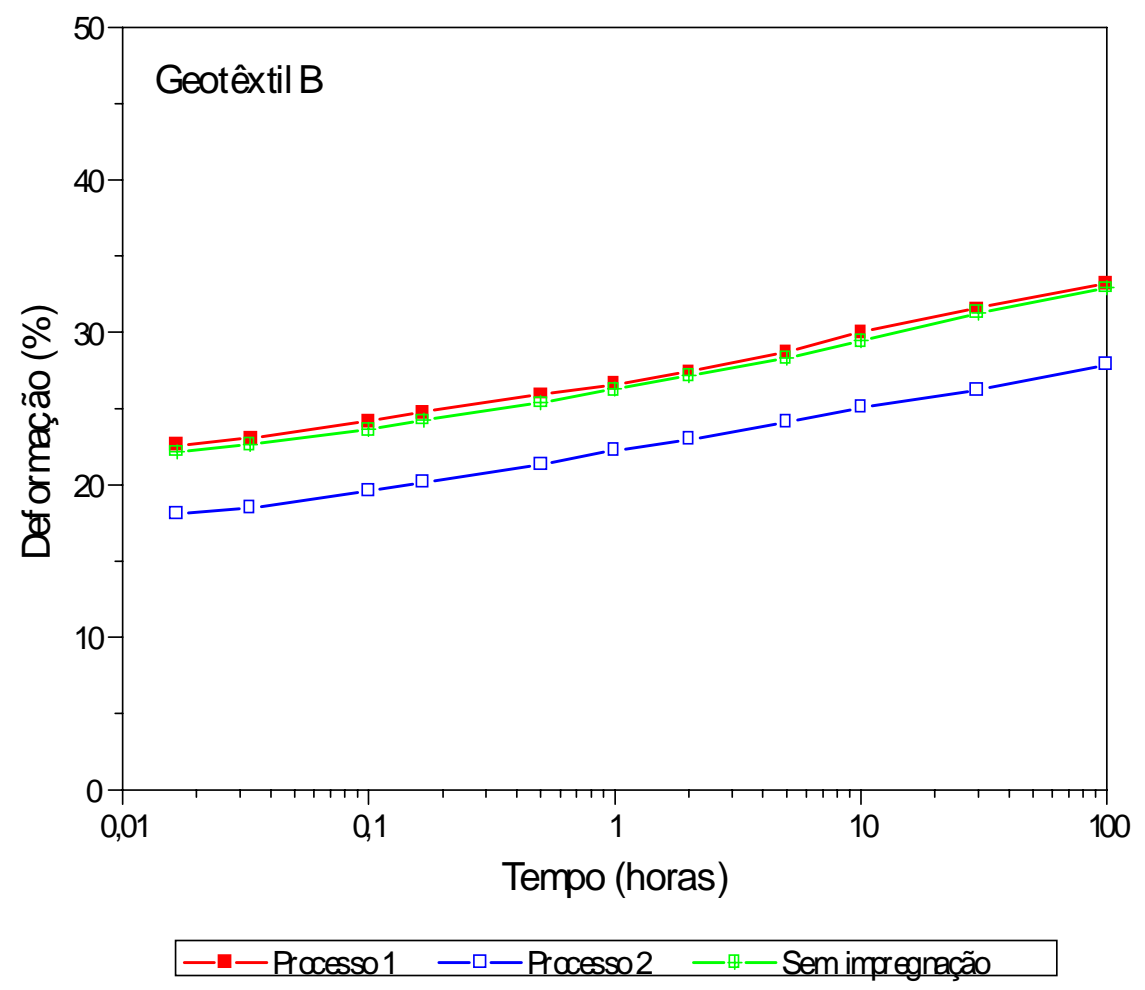

FIGURA 4.17 - Resultados de ensaios confinados - 40\% da resistência à tração e $50 \mathrm{kPa}$ (ensaios C1, C3 e C4).

Com relação ao segundo processo (preparação da lama), as deformações totais ao longo do tempo foram inferiores às apresentadas em ensaios sem impregnação. Contudo, o efeito preponderante das partículas imbricadas parece ser o de reduzir as deformações imediatas. Nenhuma alteração significativa de comportamento, realmente ao longo do tempo, fica visível, como por exemplo, a redução da taxa de deformação observada nos ensaios confinados em relação àqueles sem confinamento (Figura 4.15). Em termos da constante b, os resultados foram: 2,88 e 2,63 para os ensaios sem e com impregnação, respectivamente.

Algumas fotos tiradas no microscópio eletrônico, demonstraram coerência com esses resultados. Primeiramente, a Figura 4.18 apresenta a estrutura do geotêxtil utilizado. Observando-se a Figura 4.19 que mostra uma região do corpo de prova preparado pelo processo 1, percebe-se apenas um aspecto de "sujeira" (algumas partículas presas às fibras mais superficiais). Neste caso, não parece ser provável uma mudança de comportamento, como atestaram os resultados dos ensaios. Já algumas fotos de partes de um corpo de prova preparado pelo segundo processo (Figuras 4.20 e 4.21 ) demonstram uma presença bem mais significativa de partículas 
nos poros da manta, mostrando realmente ser possível comportamentos distintos entre corpos de prova preparados pelo processo 2 e sem impregnação.

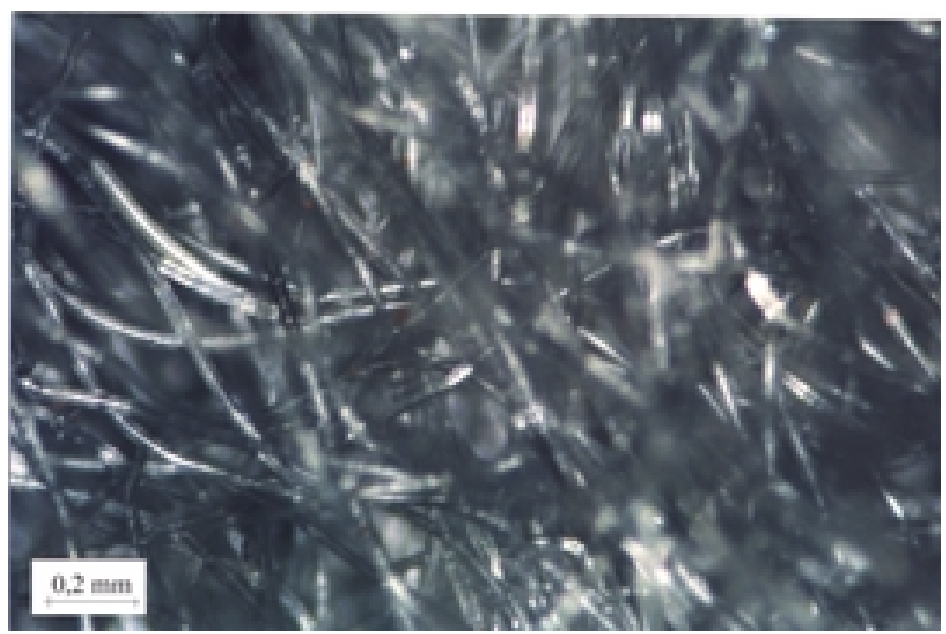

FIGURA 4.18 - Estrutura do geotêxtil B (ampliação de 50x).

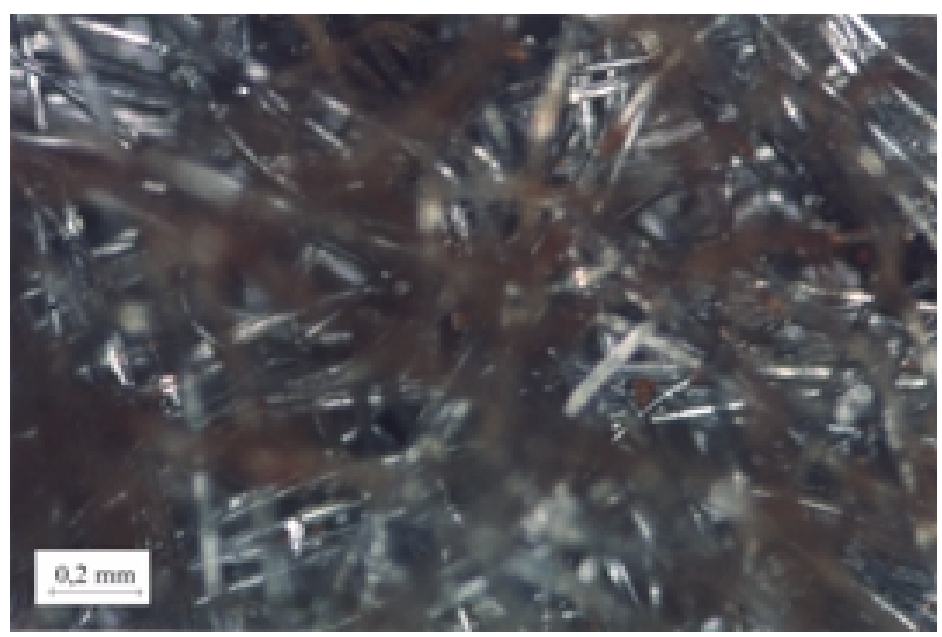

FIGURA 4.19 - Geotêxtil B preparado pelo processo 1 após ensaio (ampliação de 50x) 


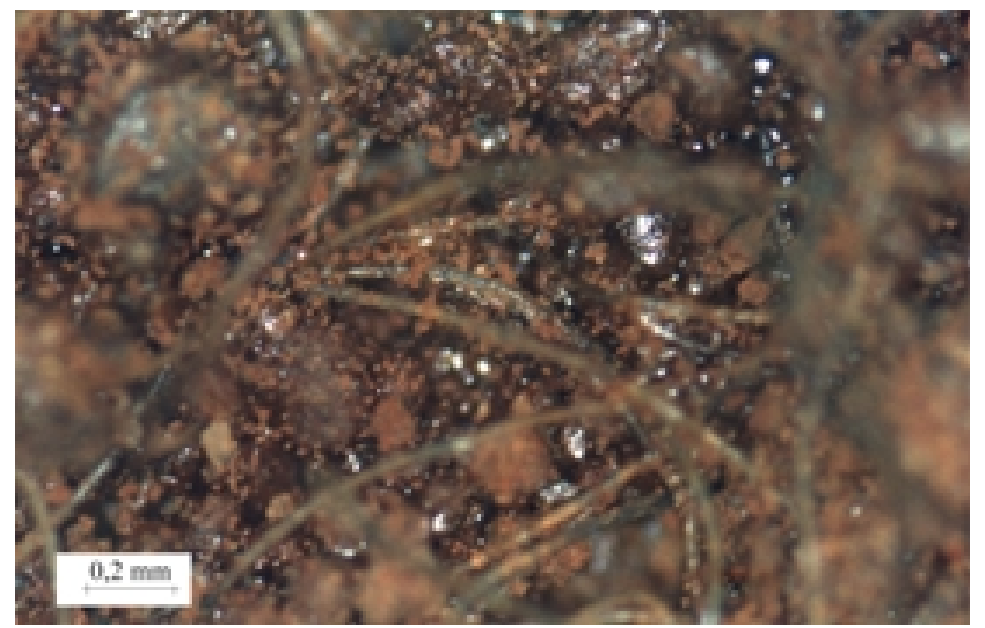

FIGURA 4.20 - Geotêxtil B preparado pelo processo 2 após ensaio - região aparentemente mais impregnada (ampliação de 50x).

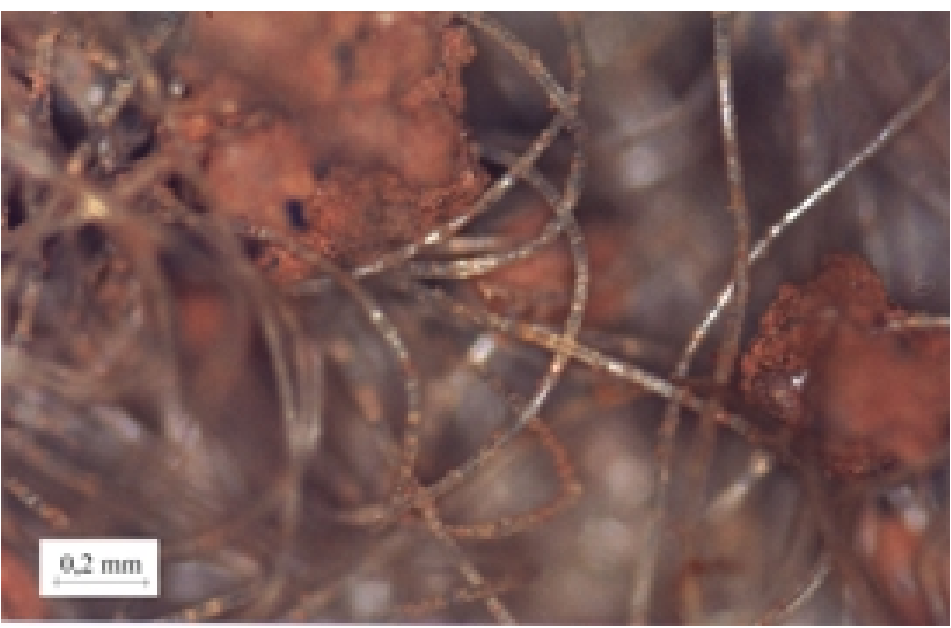

FIGURA 4.21 - Geotêxtil B preparado pelo processo 2 após ensaio - região aparentemente menos impregnada (ampliação de 50x).

A alteração pouco significativa da fluência considerando os resultados dos ensaios com corpos de prova preparados pelo processo da lama, também demonstrou a viabilidade de se executar os ensaios apenas com membranas. Claro que o ideal seria manter o geotêxtil entre camadas de solo, mas diante das dificuldades já mencionadas, ensaios de fluência confinando-se o geotêxtil apenas com a membrana parecem ser promissores. Devendo-se investigar ainda, o comportamento do geotêxtil mediante outros tipos de solo. 
Todos os resultados demonstraram a acentuada tendência dos geotêxteis em apresentar fluência, além da possibilidade de ruptura, as próprias deformações totais apresentadas nos ensaios, já denotaram a necessidade de adoção de coeficientes de segurança elevados a fim de garantir as condições de serviço de uma determinada estrutura de solo reforçado. O efeito do confinamento de reduzir as deformações totais, felizmente, pode possibilitar a redução dos coeficientes de segurança atualmente utilizados (baseados em ensaios não-confinados), usufruindo-se consequentemente de obras mais econômicas. 


\section{Conclusões e sugestões para PESQUisas FUTURAS}

\subsection{Condusões}

Do exposto no presente trabalho pode-se concluir que:

a) o equipamento desenvolvido para realizar ensaios de fluência não-confinada mostrou um desempenho satisfatório, já o confeccionado para os ensaios confinados apresentou algumas limitações (problemas de atrito e adesão) que podem entretanto, ser contornadas adequando-se as condições do ensaio (gramatura, carga aplicada, etc) às limitações do equipamento de tal forma que ainda seja possível investigar o aspecto inicialmente desejado;

b) a construção de um equipamento capaz de evitar por completo efeitos de atrito e adesão na interface solo-geotêxtil, em ensaios de fluência confinada, consiste em uma tarefa de enorme complexidade;

c) ensaios em que se confine o geotêxtil sem solo, apenas utilizando membranas, parecem ser promissores, sendo muito mais viáveis por exemplo, para gerar dados a serem incorporados nos catálogos dos fabricantes a fim de caracterizar a fluência de determinado produto;

d) para geotêxteis de polipropileno, a deformação associada à ruptura em ensaios de fluência pode ser bem superior à obtida em ensaios de tração; 
e) a fluência do geotêxtil de poliéster foi bem menor em relação aos geotêxteis de polipropileno: cerca de 10 vezes inferior para um carregamento correspondente a $40 \%$ de suas resistências à tração;

f) o confinamento reduziu as deformações ao longo do tempo para o geotêxtil utilizado. Para uma pressão aplicada de $50 \mathrm{kPa}$, a taxa de deformação foi até 2,8 vezes menor em relação à condição não-confinada;

g) para os ensaios confinados com modificações na preparação dos corpos de prova, considerando o solo utilizado, o processo de compactação não provocou impregnação de partículas na manta e, embora o segundo processo (preparação da lama) tenha provocado certa impregnação, as partículas de solo que penetraram na manta praticamente não alteram a fluência.

\subsection{Sugestões para pesquisas futuras}

Tendo em vista o que foi apresentado e considerando a necessidade de elucidação de algumas questões sobre fluência de geotêxteis não-tecidos, sugerem-se os seguintes aspectos para futuras pesquisas:

a) realizar ensaios de fluência confinada e não-confinada utilizando um mesmo geotêxtil e diferentes gramaturas, já que a garantia de não alteração da fluência com a gramatura possibilitaria reduzir consideravelmente os esforços e o tempo necessário por exemplo, para produzir as informações sobre fluência que devem constar no catálogo dos fabricantes;

b) realizar ensaios confinados aplicando-se diversos níveis de pressão, tentando-se estabelecer uma relação entre a pressão aplicada e o correspondente efeito do confinamento. Selecionado é claro, um carregamento adequado a fim de as perdas em virtude de atrito e adesão possam ser consideradas desprezíveis em relação à carga aplicada; 
c) realizar ensaios confinados em número suficiente a fim de propor coeficientes de segurança com relação à ruptura, verificando a possibilidade dos mesmos serem incorporados aos projetos;

d) realizar ensaios confinados para cargas reduzidas, entre 10 e $20 \%$ da resistência à tração (intervalo de valores obtido para as cargas atuantes no reforço em muitos muros e taludes instrumentados) a fim de fornecer dados para estimativas das deformações esperadas no término de vida útil das obras. Devendo-se identificar também, a expressão ou modelo reológico mais indicado para a extrapolação dos dados. 


\section{REFERÊNCIAS BIBLIOGRÁFICAS}

ABRAMENTO, M. (1995). Durabilidade e comportamento de longo prazo de geossintéticos - Parte I: Propriedades mecânicas e hidráulicas. In: Geossintéticos 95. Anais. São Paulo, p. 217-226.

ALLEN, T. M. (1991). Determination of long-term strength of geosynthetics: A state-of-the-art review. In: Geosynthetics' 91. Proceedings. Atlanta. v. 1, p.351379.

ALLEN, T. M.; BATHURST, R. J. (1996). Combined allowable strength reduction factor for geosynthetic creep and installation damage. Geosynthetics International, v. 3, n. 3, p. 407-439.

AMERICAN SOCIETY FOR TESTING AND MATERIALS (1994). ASTM D5262 - Standard test method for evaluating the unconfined tension creep behavior of geosynthetics. In: Annual book of ASTM standards. New York, p. 244-249.

ASSOCIAÇÃO BRASILEIRA DE NORMAS TÉCNICAS (1991). NBR 12553 Geotêxteis. Rio de Janeiro.

ASSOCIAÇÃO BRASILEIRA DE NORMAS TÉCNICAS (1992). NBR 12568 Geotêxteis - Determinação da gramatura. Rio de Janeiro.

ASSOCIAÇÃO BRASILEIRA DE NORMAS TÉCNICAS (1992). NBR 12593 Amostragem e preparação de corpos de prova de geotêxteis. Rio de Janeiro.

ASSOCIAÇÃO BRASILEIRA DE NORMAS TÉCNICAS (1993). NBR 12824 Geotêxteis - Determinação da resistência à tração não-confinada - Ensaio de faixa larga. Rio de Janeiro.

BALLEGEER, J. P.; WU, J. T. H. (1993). Intrinsic confined and unconfined loaddeformation properties of geotextiles. In: CHENG, S. J. C. Geosynthetics soil reinforcement testing procedures. Philadelphia. p. 16-31.

BATHIA, S. K.; SMITH, J. L. (1996). Geotextile characterization and pore-size distribution: Part 1. A review of manufacturing processes. Geosynthetics International, v. 3, n. 1, p. 85-105.

BILLMEYER, F. W. (1984). Textbook of polymer science. Singapore, John Wiley \& Sons.

CASSIDY, P. E; MORES, M.; KERWICK, D. J.; KOECK, D. J.; VERSCHOOR, K. L.; WHITE, D. F. (1992). Chemical resistance of geosynthetic materials. Geotextiles and Geomembranes, v. 11, n. 1, p.61-98. 
CAZZUFFI, D.; GHINELLI, A.; SACCHETTI, M.; VILLA, C. (1997). European experimental approach to the tensile creep behavior of high-strength geosynthetics. In: Geosynthetics' 97. Proceedings. California. v.1. , p.253-266.

COOKE, T. F.; REBENFELD, L. (1988). Effect of chemical composition and physical structure of geotextiles on their durability. Geotextiles and Geomembranes, v. 7, $\mathrm{n}^{\mathrm{os}}$. 1 e 2, p.7-22.

DANIELS, C. A. (1989). Polymers: structure and properties. Lancaster, Technomic Publishing Company.

DEN HOEDT, G. (1988). Durability of geotextiles. London, Chapman and Hall. p.34-38: Principles of creep and relaxation.

DEN HOEDT, G. (1986). Creep and relaxation of geotextile fabrics. Geotextiles and Geomembranes, v. 4, n. 2, p. 83-92.

EL-FERMAOUI, A.; NOWATZKI, E. (1982). Effect of confining pressure on performance of geotextiles in soils. In: International Conference on Geotextiles, $2^{\text {nd }}$. Proceedings. Las Vegas, v. 3, p. 799-804.

FARRAG, K. (1997). Prediction of long-term strains of geosynthetics from accelerated-creep tests. In: Geosynthetics' 97. Proceedings. California. v.1. , p. 267-276.

GOMES, R. C. (1993). Interação solo-reforço e mecanismos de ruptura em solos reforçados com geotêxteis. São Carlos. 270p. Tese (Doutorado) - Escola de Engenharia de São Carlos, Universidade de São Paulo.

GREENWOOD, J. H. (1990). Creep of geotextiles. In: Geotextiles, Geomembranes and Related Products, $4^{\text {th }}$, The Hague, 1990. Proceedings. Rotterdam, Balkema. v.2, 645-650.

GREENWOOD, J. H. (1998). Derivation of design parameters and partial safety factors from laboratory data. In: Creep and Assessment of Geosynthetics for Soil Reinforcement, Leatherhead, 1997. Proceedings, Leatherhead, p.3.1-3.11.

GREENWOOD, J. H.; MYLES, B. (1986). Creep and stress relaxation of geotextiles. In: International Conference on Geotextiles, $3^{\text {rd }}$. Proceedings. Vienna, v.3, p. 821-826.

HORROCKS, A. R.; D'SOUZA, J. A. (1992). Degradation of polymers in geomembranes and geotextiles. In: HAMID, S. H. et al. Handbook of polymer degradation. New York, Marcel Dekker. Cap. 15, p. 433-505.

JEWELL, R. A. (1991). Application of revised design charts for steep reinforced slopes. Geotextiles and Geomembranes, v. 10, n. 3, p. 203-233. 
JEWELL, R. A. (1996). Soil reinforcement with geotextiles. London, CIRIA. Cap. 2, p. 15-30: Polymer and geotextile properties.

JEWELL, R. A.; GREENWOOD, J. H. (1988). Long term strength and safety in steep soil slopes reinforced by polymer materials. Geotextiles and Geomembranes, v. 7, nos 1 e 2, p.81-118.

JOHN, N. W. M. (1987). Geotextiles. New York, Chapman and Hall.

KOERNER, R. M. (1994). Designing with geosynthetics, Englewood Cliffs, New Jersey, Prentice Hall, $3^{\text {rd }}$ Ed.

KOERNER, R. M.; LORD, A. E. Jr.; HSUAN, Y. H. (1992). Arrhenius modeling to predict geosynthetic degradation. Geotextiles and Geomembranes, v. 11, n. 2, p.151-183.

KOKKALIS, A.; PAPACHARISIS, N. (1989). A simple laboratory method to estimate the in-soil behavior of geotextiles. Geotextiles and Geomembranes, v. 8, n. 2, p. 145-157.

KOUTSOURAIS, M. (1995). Correlating the creep-strain component of the total strain as a function of load-level for high-tenacity polyester yarns, geogrids and geotextiles. In: Geosynthetics' 95. Proceedings. Tennessee. v.3. , p.989-1001.

LESHCHINSKY, D.; BOEDEKER, R. H. (1989). Geosynthetic reinforced soil structures. Journal of Geotechnical Engineering, v. 115, n. 10, p. 1459-1478.

LESHCHINSKY, D.; FIELD. D. A.; (1987). In-soil load elongation, tensile strength and interface friction of non-woven geotextiles. In: Geosynthetics' 87, New Orleans, 1987. Proceedings. p. 238-249.

LESHCHINSKY, D.; PERRY, E. B. (1989). On the design of geosyntheticreinforced walls. Geotextiles and Geomembranes, v. 8, n. 4, p. 311-323.

LEVACHER, D.; BLIVET, J. C.; MSOUTI, F. (1994). Tensile and creep behavior of geotextiles. In: Geotextiles, Geomembranes and Related Products, $5^{\text {th }}$. Proceedings. Singapore. v.3, p. 1131-1134.

LING, H. I.; WU, J. T. H.; TATSUOKA, F. (1992). Short-term strength and deformation characteristics of geotextiles under typical operational conditions. Geotextiles and Geomembranes, v. 11, n. 2, p. 185-219.

MANO, H. B. (1985). Introdução a polímeros. São Paulo, Edgard Blücher.

MANO, H. B. (1991). Polímeros como materiais de engenharia. São Paulo, Edgard Blücher. 
MARK, H. F.; BIKALES, N. M.; OVERBERGER, C. G; MENGES, G. (1986). Encyclopedia of polymer science and engineering, v. 6 - Fibers; v. 10 Nonwoven Fabrics.

MATICHARD, Y.; LECLERCQ, B.; SEGOUIN, M. (1990). Creep of geotextiles: soil reinforcement applications. In: Geotextiles, Geomembranes and Related Products, $4^{\text {th }}$, The Hague, 1990. Proceedings. Rotterdam, Balkema. v.2, p. 661665.

McGOWN, A.; ANDRAWES, K. Z.; KABIR, M. H. (1982). Load-extension testing of geotextiles confined in soil. In: International Conference on Geotextiles, $2^{\text {nd }}$. Proceedings. Las Vegas, v. 3, p. 793-798.

McGOWN, A.; ANDRAWES, K. Z.; MURRAY, R. T. (1986). The load-strain-timetemperature behavior of geotextiles and geogrids. In: International Conference on Geotextiles, $3^{\text {rd }}$. Proceedings. Vienna, v.3, p. 707-712.

MIKI, H.; HAYASHI, Y.; YAMADA, K.; TAKASAGO, T.; SHIDO, H. (1990). Plane strain tensile strength and creep of spun-bonded non-wovens. In: Geotextiles, Geomembranes and Related Products, 4 ${ }^{\text {th }}$, The Hague, 1990. Proceedings. Rotterdam, Balkema. v.2, 667-672.

MSOUTI, M. F.; BLIVET, J. C.; LEVACHER, D. (1997). Comportement au fluage des géotextiles en reforcement mécanique. Études et recherches des laboratories des Ponts et Chaussées, GT n. 63.

MÜLLER-ROCHHOLZ, J. (1998). Practicalities of measurement of creep and stress rupture. In: Creep and Assessment of Geosynthetics for Soil Reinforcement, Leatherhead, 1997. Proceedings, Leatherhead, p.1.1-1.12.

MÜLLER-ROCHHOLZ, J.; KIRSCHNER, R. (1990). Creep of geotextiles at different temperatures. In: Geotextiles, Geomembranes and Related Products, $4^{\text {th }}$, The Hague, 1990. Proceedings. Rotterdam, Balkema. v.2, p. 657-659.

MURRAY, R. T.; McGOWN, A. (1988). Durability of geotextiles. London, Chapman and Hall. p.52-73: Assessment of the time dependent behavior of geotextiles for reinforced soil applications.

NICHOLSON, J. W. (1991). The chemistry of polymers. Cambridge, The Royal Society of Chemistry.

PALMEIRA, E. M. (1991). Análise da evolução da técnica de reforço de solos por inclusões extensíveis na última década. Solos e Rochas, v. 14, n. 2, p.95-107.

PALMEIRA, E. M. (1990). Um equipamento para ensaios de tração confinada em geotêxteis. Universidade de Brasília. Relatório interno (não publicado).

ROCHA, A. P. F. (1985). Geotêxteis: matéria-prima. Geotecnia, n.44, p.105-116, jul. 
ROSEN, S. L. (1982). Fundamental principles of polymeric materials. New York, Wiley-Interscience. Cap 22, p.319-320: Synthetic fibers.

SAWICKI, A.; KAZIMIEROWICZ-FRANKOWSKA, K. (1998). Creep behavior of geosynthetics. Geotextiles and Geomembranes, v. 16, n. 6, p. 365-382.

SHRESTHA, S. C.; BELL, J. R. (1982). Creep behavior of geotextiles under sustained loads. In: International Conference on Geotextiles, $2^{\text {nd }}$. Proceedings. Las Vegas, v. 3, p. 769-774.

SIEL, B. D.; TZONG, W. H.; CHOU, N. N. S. (1987). In-soil stress-strain behavior of geotextiles. In: Geosynthetics'87, New Orleans, 1987. Proceedings. p. 260265.

SILVA, L. C. R. (1996). Análise do comportamento de muros reforçados em condições de trabalho. São Paulo. 203 p. Dissertação (Mestrado) - Escola Politécnica, Universidade de São Paulo.

SOONG, T.; KOERNER, R. M. (1998). Modeling and extrapolation of creep behavior of geosynthetics. In: International Conference on Geosynthetics. Geotextiles, $6^{\text {th }}$. Proceedings. Atlanta, v. 2, p. 707-710.

THORNTON, J. S.; ALLEN, S. R.; THOMAS, R. W. (1997). Approaches for the prediction of long term viscoelastic properties of geosynthetics form short term tests. In: Geosynthetics '97. Proceedings. California. v.1. , p.277-291.

TUPA, N. (1994).Estudo da aderência e interação solo-geossintético. Brasília. 168 p. Dissertação (Mestrado) - Universidade de Brasília.

TUPA, N.; PALMEIRA, E. M. (1995). Comportamento de geotêxteis não-tecidos confinados em solos finos. In: Geossintéticos 95. Anais. São Paulo, p. 139-147.

VAN ZANTEN, R. V. (1986). Geotextiles and geomembranes in civil engineering. Rotterdam, Balkema.

WILSON-FAHMY, R. F.; KOERNER, R. M.; FLECK, J. A. (1993). Unconfined and confined wide width tension testing of geosynthetics. In: CHENG, S. J. C. Geosynthetics soil reinforcement testing procedures. Philadelphia. p. 49-63.

WU, C. S.; HONG, Y. S. (1994). Creep behavior of geotextile under confining stress. In: Geotextiles, Geomembranes and Related Products, $5^{\text {th }}$. Proceedings. Singapore. v.3, p. 1135-1138.

WU, J. H. T.; ARABIAN, V. (1990). Cubical and cylindrical tests for measuring insoil load-extension properties of geotextiles. In: Geotextiles, Geomembranes and Related Products, $4^{\text {th }}$, The Hague, 1990. Proceedings. Rotterdam, Balkema. v.2, p. 785. 
WU, J. T. H. (1991). Measuring inherent load-extension properties of geotextiles for design of reinforced structures. Geotechnical Testing Journal, v. 14, n. 2, p. 157165 .

ZAMMITT, R. A. (1998). Approval procedures for geosynthetics for soil reinforcement application - UK practice. In: Creep and Assessment of Geosynthetics for Soil Reinforcement, Leatherhead, 1997. Proceedings, Leatherhead, p.5.1-5.20. 


\section{APÊNDICE}

EQUIPAMENTO DE FLUÊNCIA CONFINADA

- Dimensões em mm

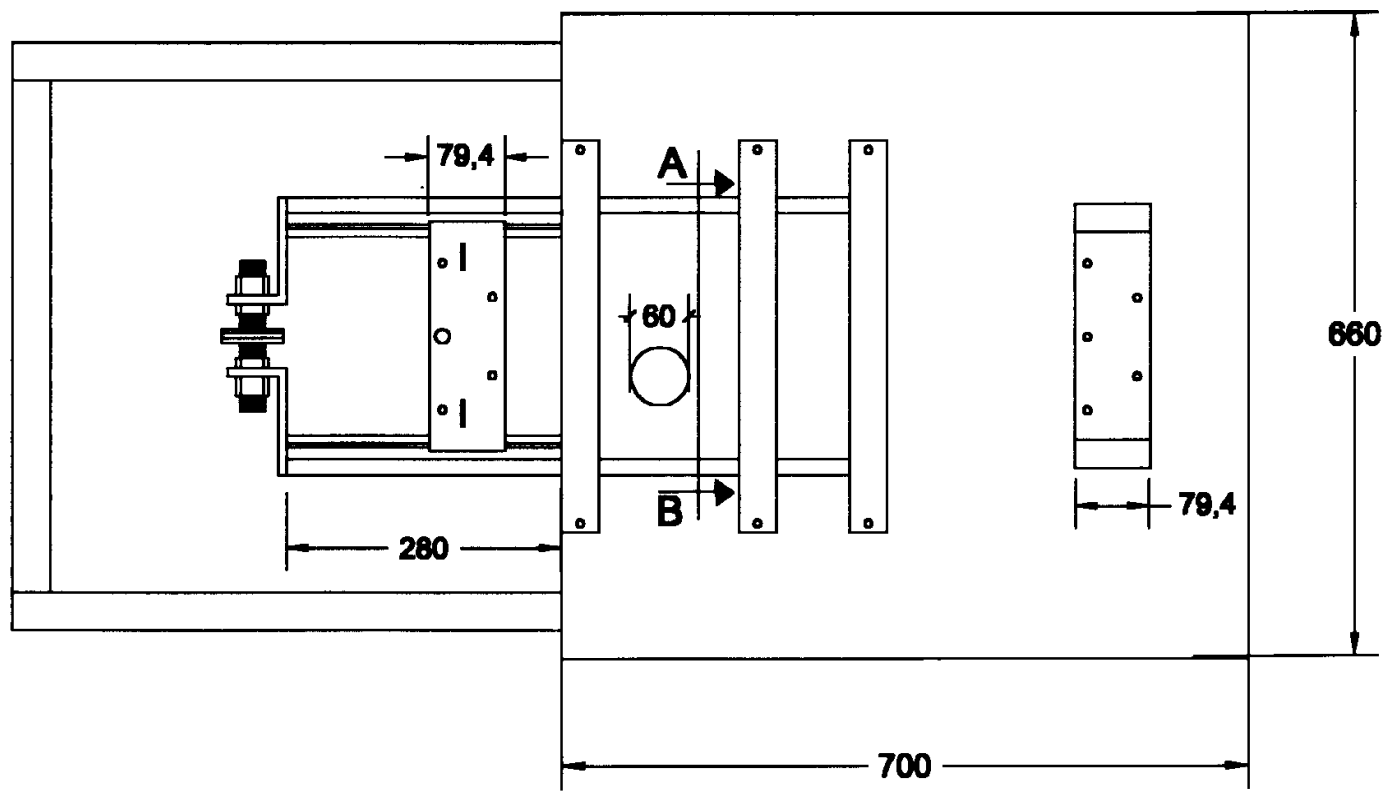

VISTA SUPERIOR DO EQUIPAMENTO 


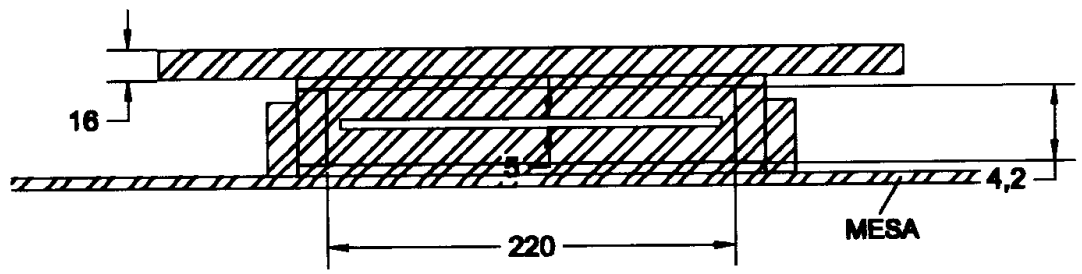

CORTE AB

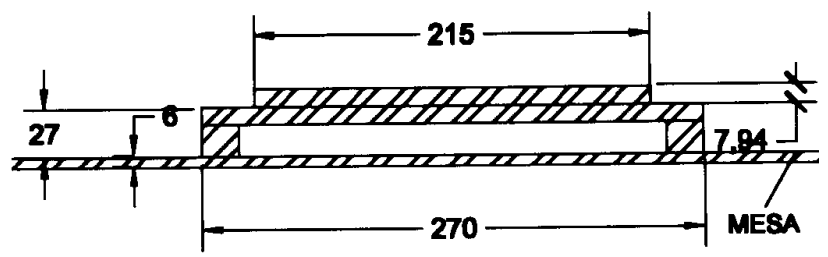

DETALHE DA GARRA FIXA

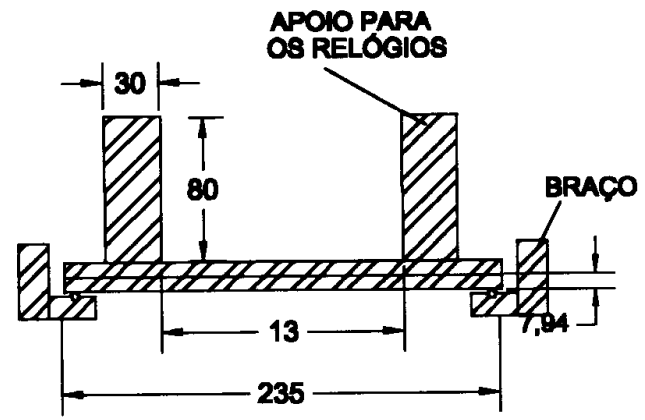

DETALHE DA GARRA MÓVEL

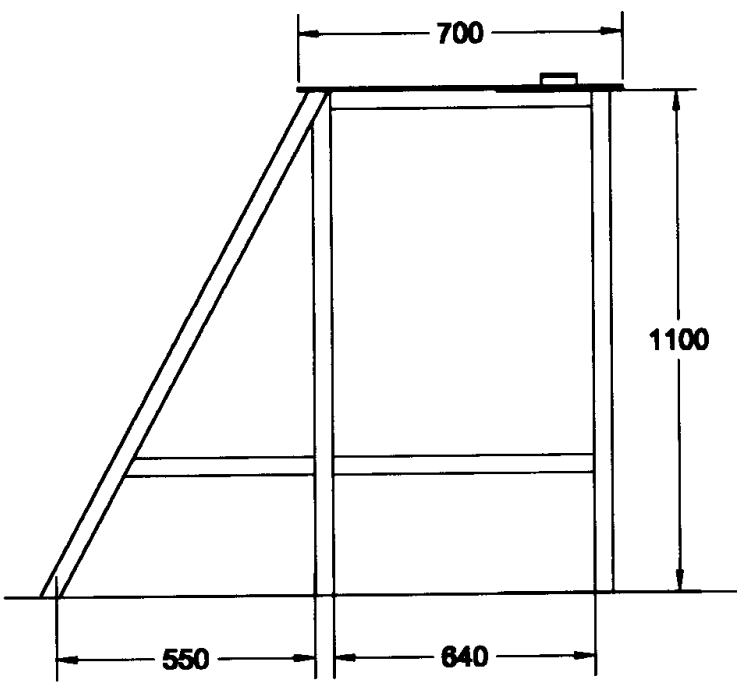

VISTA LATERAL DA MESA DE APOIO 